

$z-8$

Hofriedmann

Presented to the U.S.M.M. Libsary by Dr. Friedmann

Mouch 1940 



\section{Division of Bieds}

\section{A STUDY \\ OF THE \\ InCUBATION PERIODS \\ OF \\ BIRDS}

WHAT DETERMINES THEIR

LENGTHS?

BY

W. H. BERGTOLD, M. D., M. Sc.

Member of the American Ornithologists' Union

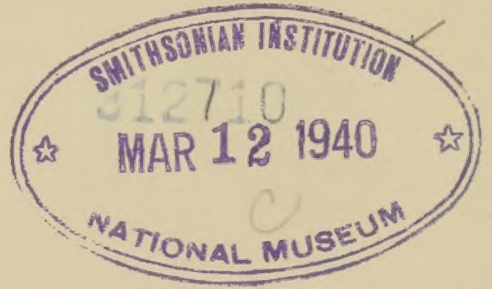

THE KENDRICK-BELLAMY CO.

DENVER, COLORADO

1917 
Copyright, 1917

By W. H. BERGTOLD

PRESS OF

Carson-Harper Co.

2019 Stout St.

Denver, Colo. 


\section{P R E F A C E}

In the course of certain studies in ornithology, more particularly avian physiology, undertaken by the author several years ago, it early became apparent that the factors fixing or determining the length of the incubation period with different birds was largely, if not wholly, unknown.

The following pages give the results of a prolonged and detailed study of this phase of bird physiology.

The author regards all zoologic classification as a means, not an end; the classification adopted in this work is merely a means of facilitating the handling of a mass of data full of contradictions and uncertainties, and the selection of this particular bird classification was governed by a question of expediency only; obviously the author in no way wishes to be understood as believing this classification to be the best, or the only one. The author believes, however, that this classification is an up-to-date reflection of our present knowledge of the relation of various birds to each other.

It is inevitable that mistakes of various sorts will be found in this book; in extenuation of such errors the author trusts that his crities will recall that the labor involyed in the investigations reviewed in the following pages was one of love, and carried on in the spare moments of a fairly busy professional life.

A brief resumé of pages 43 to 76 of this book was read before the Annual Meeting of the American Ornithologists' Union at Philadelphia, November 15, 1916.

It is a keen pleasure here to acknowledge, with many thanks, my obligations to the following friends, who have generously placed at my disposal incubation data, and cognate information, all of which has been invaluable in the preparation and prosecution of this study: C. W. Beebe, B. Rhett Chamberlain, L. J. Cole, E. W. Collins, L. S. Crandall, Louis Fuertes, J. D. Figgins, W. F. Kendrick, F. H. Knowlton, D. E. Lantz, F. C. Lincoln, W. DeW. Miller, R. C. Murphy, J. T. Nichols, R. J. Niedrach, Clyde Phillips, W. S. Pickrell, Robert Ridgway, A. A. Saunders, Sutherland Simpson, Witmer Stone, F. M. Watson, C. A. Watts and A. P. Wilbur.

The Author.

Denver, Colo.,

June 15, 1917. 



\section{S Y N O P S I S}

1-Introduction: The Problem.

2-Definitions; Length of Incubation-

* How measured.

** Difficulties of fixing beginning and end.

*** True or specific length of incubation.

**** False or apparent length of incubation.

Types of hatching-

* Successive.

** Simultaneous.

3-The Data-

* The amount.

*** The sources.

**** Explanations of conflicts in.

***** Obvious errors in.

4-Influences actually or seemingly altering the specific length of incubation-

* Causing real variability.

** Causing apparent variability.

5-What determines the true or specific length of incubation-

* Past Theories:

A-The parent, or the bird itself-

(a) Its size or weight.

(b) The age of the female.

(c) Condition of the parents.

(d) Faithfulness of the parents while incubating.

(e) Longevity of the parents.

(f) Condition of young at hatching.

* Precocious.

** Altricial.

*** Completeness of development at hatching.

B-The Egg-

(a) Its size or weight.

(b) Its age or viability.

(c) Its shell.

(d) Its yolk size.

C-Telluric Conditions-

(a) Zone.

(b) Climate.

(c) Weather.

(d) Geographical location of species.

(e) Site of nest. 
** New Theories:

A-Body-weight: Egg-weight Index.

B-Temperature and Ascent Theory.

* Bird temperature.

** Rapidity of metabolism or "swiftness of life." ***'Temperatures, incubation lengths, and taxonomic position.

***** Collateral evidence.

6-Present data and this new theory.

7 -Usefulness of new theory.

8-Does correlation of temperature and incubation length benefit species?

9-Data need for further study of this problem.

10-Conclusions-

A-Minor.

B--Major.

11-List of incubation periods.

12-Bibliography. 


\section{A STUDY OF THE INCUBATION PERIODS OF BIRDS}

What controls the length of incubation with birds? It is the purpose of this study to find, if possible, a correct answer to this question.

\section{Introduction}

The processes going on within an egg during incubation are of fundamental and paramount importance to the species and race, in no way less than the process of fertilization; fertilization and incubation are co-equal and interdependent, and through them the time space between generations is bridged and the race perpetuated. Fertilization is governed by definite limitations and conditions. Does it seem reasonable to believe that the length of the equally important period of time necessary to complete the marvelous steps of development following fertilization is a matter of chance, a "hit or miss" duration?

It is inconceivable that such can be true; one arises from a study of the embryology of the "chick" in amazement that the wonderful and complex changes in an egg from a single cell to a peeping chicken can be brought about in a brief three weeks. Such perfection of detail, with all its potential specific and racial conditions unfolded, must surely require a fixed and definite period of time for its completion. Does it not seem more reasonable that this period of time must be relatively fixed for each species, and be controlled by factors or conditions which collectively might be called a law?

I believe that a knowledge of such factors, or such a law, is not merely academic, but, on the contrary, is of decided importance, and constitutes a block to be fitted in the mosaic being slowly put together by ornithologists, each in his day. Moreover, the writer has discovered, through his study of the question. that it is fraught with fascinating interest, and, too, opens up unexpected and wide fields for original research.

\section{The Problem}

The problem in hand is to answer the question, Why does a house finch's egg take fourteen days to hatch, an ostrich's forty-two days, an emu's fifty-six days, or a hummingbird's fourteen days? It is the work of this study to analyze the published data concerning incubation periods, and to examine the explanations heretofore given, as to what governs the length of incubation, and to determine if 
there be a law which controls the length of incubation, or at least to detect indications of such a law, or to point out lines of investigation which give promise of being helpful in reaching a final solution of the problem.

\section{Definitions}

In this discussion the term incubation is held to mean the period of time during which heat is applied more or less continuously to a set of eggs, a period varying within a wide range according to the species; by "incubation period" is meant the whole time so involved, regardless of its duration; and by "length of incubation" is meant the number of days or weeks necessary to completely hatch the young.

The records of incubation as given in the literature on the subject embrace two varieties of lengths: (A) - the true length (or specific length), and (B) - the false length (or apparent length); the first, or true length, being the minimum number of days, under optimum conditions, necessary to hatch a normal bird, while the second is the true length, plus or minus the time added to, or subtracted from, it by errors in observation, or through errors caused by the different types of hatching, types to be defined later on, or plus the time added to it by such conditions as retard or temporarily suspend embryonic development. With birds which lay a considerable number of eggs in each set, and only begin to incubate when the set is completed, it is not difficult to fix the beginning of the incubation period, as with eiders (137); when, however, several eggs are laid in a set, and the female warms the first eggs more or less while the other eggs of the set are being laid, it is impossible to say exactly when the period of incubation begins, and the incubation duration has to be determined for each egg by marking it when laid.

It is almost impossible at times to decide when the parent actually begins steadily to apply the heat necessary to successful hatching. It is also extremely difficult to estimate how much heating the first eggs receive while a whole set is being laid, a fact necessitating one's defining the different types of hatching, so as to keep in mind the effects of a parent's partially heating the first laid eggs. It has been shown $(92)$ that the domesticated pigeon's a verage incubation period is seventeen days, the eggs (two in a set) being laid on alternate days; the second egg usually hatches in (almost) exactly seventeen days, while the first takes eighteen and one-half days, measured from the day it is laid. If it be assumed that the real incubation begins with the laying of the second egg, it becomes manifest that the first egg receives the equivalent of one-half a day incuba- 
tion while the set of eggs is being laid. That this is true cannot be questionerl. since it has been found (92) by "candling" pigeons" eggs that the first eqg shows indubitable evidences of beginning embryonic development by the time the second egg is laid. It is also wise here to recall that all eggs respond developmentally to lower degrees of temperature in the early parts of incubation than they do in the later or last portions.

Hence, from the foregoing, it is evident that the difficulty of fixing the real beginning of incubation must contribute not a little to conflicts in the data on incubation length, and has led to honest differences in the records made on a given species by different observers. The correct and exact method of measuring the length of incubation is to mark each egg as laid and watch it daily until hatched. This is often impossible because of psychic reasons, since a bird may abandon a nest if too closely watched, or because of physical reasons, as with birds nesting in holes. Some errors have also been caused by lack of agreement as to when the incubation terminates: thus some reports seem to indicate that the observers date the end of incubation when the egg is merely "pipped," while others fix the end when the "chick" is completely hatched.

In cases where several eggs make a set for a single hatching, all the eggs may hatch at the same (relatively) time, in which event I propose to name it a "simultaneous hatching," as is seen with the domestic hen, and when the eggs hatch one after another at intervals of a day or two, a "successive hatching." The effects of these two types of hatching on the estimation of incubation length will be considered later on.

\section{Conditions Necessary for Successful Incubation}

The growth of a new bird individual really begins directly after fertilization, which may occur a considerable time before the egg is completed and extrudert: consequently, the incubation period embraces only part of a bird's embryonic development, which part is, however, by far the largest portion of the process of revelopment.

Successful incubation depends on "keeping a fertile egg * * * for a sufficient period of time under certain conditions of heat, moisture and position" $(33) *$

This combination of heat, moisture and position is achieved through the brooding of the parent (real or foster), or by a mass of decaying regetable matter, or by hot springs, or through the care of the parents plus the sun's heat. It mav begin at once, after the first egg is laid, or after part

*Numbers in parentheses correspond to the number of the authority quoted, and as listed in the bibliography. See Table No. 2. 
of a full set of eggs is laid, or only after all of a full set is laid.

I believe that the evidence permits one to hold that the true length of incubation varies little, if at all, with the species, however widely separated geographically, a view substantiated by the Old and New World cuckoos, and the small finches of the Northern Hemisphere and Australia. However, the work of Cole and Kirkpatrick (92) seems to show that at least with pigeons there may be a distinct, though small. true variability in the length of incubation of these birds. Whether this be a true variability, or one due to retardation of development, is unknown to me; an answer to this point must probably be reserved until further light is shed by future studies on the true lengths of incubation in other species, and the possibility of such lengths being really variable. The length of the incubation period must be measured from the time the parent (or its substitute) begins the steady application of heat to the eggs until the young bird is fully released from its shell.

\section{The Data}

This study is based largely on the list of incubation period lengths incorporated in this book. See Table No. 1. which is made chiefly from lists published previously by Evans ( 1 and 2 ) and by Burns (3), together with records published singly by many others, plus those determined and given to the writer by obliging friends.

The incubation length data include records from 625 species and sub-species, scattered amongst $8 t$ families, and representing every order of existing bird. The writer has tried to give each record in the words of the original contributor or compiler*, and a list of all reference is given in the bibliography.

It is necessary here to note that some, perhaps many, of these records may be duplicates, an unfortunate state of affairs, but unavoidable, because some of the previons papers on the subject of this study have had no bibliographies. It were better, I believe, to include some duplicates than to exclude some original, unduplicated records, in an effort to sort out and eliminate reduplications. The present list presented now by the writer probably contains records of incubation periods of more different birds than have been gathered together in any single previous publication, a comparative wealth of material giving the writer an excuse for

*Inasmuch as a great deal of the literature used in this study was wholly inaccessible to the writer and had to be copied for him, he fears that some errors incidental to such transcribing will have crept in, for which he expresses his regret, however unavoidable on his part these errors may have been. 
trving to solve the riddle of the cause beneath the varying lengths of incubation amongst birds.

Any attempt to draw conclusions from lists of incubation periods heretofore published seems, on preliminary examination, to be hopeless; the evidence in places is highly conflicting and inconsistent, so much so that one is at once tempted to believe the length of the incubation period is a matter of more or less chance, and controlled by no particular condition or set of conditions. Fortunately, however, years of observations on domesticated birds and a vast experience in the use of artificial incubators show that this conception cannot be true, and also show that there is an actual, or a relative, fixity of the length of incubation with such species as have been so domesticated. Furthermore, the evidence seems to show that there is no inherent or known reason why a similar specific fixity should not apply to all avian species.

It is regretted that the writer did not have personal access to a larger mass of literature, for such would probably have yielded many more records of incubation, additions which would have greatly enhanced the value of these present data, and would also have saved future students of the same problem much drudgery in a search for such data. Of the nineteen thousand or more (138) species and subspecies of birds now known to ornithologists, the six hundred and twenty-five species and subspecies given in this study form but a small per cent., which may in fact be too small on which to safely base final conclusions. A future larger and more comprehensive study of the question will alone decide this.

The conclusions in this study are based on the assumption that artificial incubator records, and such other records as show a substantial concordance, are correct, and hence justifiably available as fundamental data.

\section{Conflicts in the Data}

It seems appropriate here to consider the fact that there are many conflicts in the published records of incubation lengths, and when I have been unable to examine the original record, it has been accepted as quoted. When a record has been secured by me from an original source, it has been copied revbatim, excepting in a fem instances where it was perfectly obvious from the context that the period had been incorrectly estimated because of errors induced by "successive hatching," and in such a case the writer has tried, carefully and impartially, to make corrections for such errors, and has listed the record as so corrected.

The conflicts in the records given for a single species are often numerous, and are accountable, many times, by errors brought about by the difficulty of measuring the in- 
cubation length because of "successive hatching." With sets of eggs with which the sucessive hatching type prevails, it is impossible to determine how long it takes to hatch each egg in such a set unless the eggs be marked. Let us see what can (and evidently does) happen in determining the length of inculation with the robin, a species which lays one egg each succeeding day until four or six are in the nest. Occasionally the parents do not incubate steadily until all their eggs are laid, in which case it is found that all the eggs take almost exactly fourteen days to hatch, counting from the laying of the last egg. If, however, the period be rated as beginning with the laying of the first ego, it would have to be estimated as being eighteen days, a palpable error of four days. It is more common for this species to have a set of eggs hatch irregularly; it may be one on the first day, two on the second day, and one on the third day (of the hatching period), in which case no accurate knowledge of the length of incubation could be gathered without having marked the egos for identification and individual study. Under these circumstances the first laid eggrs are partially incubated by the time the last ones are deposited, ausing the irregular hatching; and if the period were counted as extending from the laying of the last egg to the hour of the first hatching, the time elapsing would probably be ten or eleven days, an estimate three or four days too brief. I am convinced that many surprisingly short incubation periods (as recorded in literature) are much too brief, due to errors induced in the manner just outlined. I am confident that the length of incubation of the house finch is almost exactly fourteen days, but it could be variously estimated as ten or eighteen days with different sets of eggs if care were not taken to mark and carefully identify the eggs as they are laid and hatched. Under such conditions the larger the set of eggs, the longer or shorter in days of error may be the estimate of the length of incubation, errors (plus or minus) corresponding in days to the number of egos in the set, or to the number of days between the laying of the eggs. 'The effect of partial incubation when a set of eqgs is being deposited results in mixed types of hatching, an added source of conflict in the incubation length data.

On the other hand, it appears that some sets, embracing several eggs, as with the flicker (69-70), may have all the eggs hatch at once (relatively), even though the early eggs are apparently subjected to partial incubation. This may be due to the possibility that the fresher eggs (later ones laid) develop comparatively more swiftly (at the normal rate) than do the older eggs (those laid first), resulting in all breaking out at nearly the same time. The possibilities 
of observation error are much smaller with eggs hatching simultaneously. The eider (137) lays six to ten eggs before starting its incubating, and all hatch on the same day; yet, if it were not known that the steady application of heat to the eggs does not begin with this duck until all the eggs are laid, six to ten days could be erroneously added to the period of incubation.

Another fruitful source of error in computing the days of incubation is brought about by influences which retard or temporarily suspend the embryonic development, $i$. e., cooling or neglecting the eggs after they have been incubated for a while, a combination often adding several days to the true length of incubation, exemplified by the records of the ostrich and the albatross. It is also to be noted that many observers seem to date the end of incubation when the eggs are "pipped," while others report it as ended when the bird is fully hatcher. Many periods are given approximately only, indicating, perhaps, that the observer was unable to keep daily watch of the nest, or did not deem it necessary or important to determine the length of the period with exactitude, this latter possibility being the source of much discord in the records, and giving birth to such statements as "about serenteen days" or "twenty to twenty-eight days" or "after" a few weeks the young are hatched" (6it).

The evidence, it seems to me, points very strongly to the existence of a true (or specific) incubation period, which under optimum conditions varies little with each species or subspecies; hence, if there be marked discrepancies or differences in the records of such species and subspecies, it seems reasonable to believe that the records (at least in part) in such cases are inaccurate. The records of hummingbirds and wrens are good examples of conflicts, probably to be explained on the score of inaccuracy, or error in estimating the start of incubation, for it seems highly improbable that there is a difference of four days in the period of the Rubr-throated Hummingbird and the Black-throated Hummingbird, even though they are specifically distinct. while it is more improbable that there is a difference of two davs in the incubation of the Carolina and the Florida Wrens, which are but geographical races of the same species, and these remarks apply equally well to the case of the Loggerhead and Migrant Shrikes, and the Western and Eastern Meadowlarks. The Cedar Bird is a good example of how wide a difference can be found in the incubation records of a given species; the internal evidence in this instance convinces me that sixteen days is probably correct.

There are clear indications that other errors or conflicts have crept in because of typographical (or clerical) mis- 
takes, as, for example, when it is recorded by one writer that the Hummingbird's incubation period is "eighty days."

There is a singular disagreement in the recorded lengths of incubation of species which might be called semi-domesticated, as the white stork, a lack of agreement inexplicable to the writer, unless it be due to faulty observation.

It is necessary, when analyzing these data, to remember that an agreement in the records quoted by two or more different anthorities does not thereby mean that the records are conclusively correct because of such agreement, for one writer may have (and evidently has) copied from another without indicating or crediting such fact.

Conflicts and lack of consonance in the records of the length of incubation, and inconsistencies of testimony on the same, are not surprising; the writer's slight personal experience in trying to determine accurately the incubation period of a few species has shown him the many difficulties to be encountered and overcome in such a line of work. Many birds abandon a nest (and its eggs) if it be too closely watched, or if the nest be disturbed in the least; and to overcome this difficulty calls for limitless care and patience while observing the nest. It is a time-robbing task to visit a nest daily, it may be hourly, to ascertain when the eggs are laid, to mark them as laid, and to watch when they hatch, all of which must be done with some species if one is to succeed in making an accurate determination. Newton (25) long ago deplored the scantiness and inaccuracy of the then existing data on incubation. because (he said) correct data were greatly needed to check up and compare the embryology of different bird species at relatively the same stages, as an aid to put taxonomy on a sound basis. It is obrious that every ornithologist will concur in this. and the writer hopes to show later on that a more extensive and accurate knowledge of the true length of incubation of different species may help the taxonomer otherwise than through embryology. In justice to the multitude of bird students who have contributed indirectly and directly to the present list of incubation periods, one must recall that heretofore there has been no apparent indication of a need for exactitude in measuring the length of this period. Notwithstanding the unavoidable errors and discrepancies probably embodied in this list, it is a splendid commentary on the enthusiasm, care, patience and self-denial of ornithologists the world over that so many records have been made, many of which are patently of great accuracy.

From this brief survey of the conflicts in the data, it is evident that this list of incubation periods is made up of both true and apparent lengths of incubation, the latter probably being in the majority, and that it needs more 
time and extended observations, with the idea of learning the true period of incubation, to successfully sift apart these two kinds of records.

\section{Influence Altering the Incubation Length}

In this study it is assumed that the true length of incubation is a blastogenic characteristic, fixed for, and as such inherited by, each species; that it is comparatively inelastic, and yields exceedingly slowly to change: that with each species it embraces, under optimum conditions of "temperature, moisture and position," a fixed minimum number of days, just sufficient (and no more) to bring about the complete development and hatching of a normal bird. A striking proof of its inelasticity and prepotent inheritability is seen with domesticated birds, more particularly pigeons and chickens; for were this period plastic, under man's selection, as are the tissues, functions and habits of these birds, one would expect to find such plasticity showing itself in a patent variation of the incubation period of such domesticated birds. Man can, and has been able to cause, or fix, most extraordinary changes in his domesticated birds: with pigeons, not only an increase in the number of tail feathers, but even a lessening of the number of ribs (138), and with chickens, not only the almost unbelievable alteration in sizes from that of a bantam to a huge Cochin-China, but also an increase in the number of toes (the five-toed Dorkings). Man has domesticated many other birds, and if with them the period of incubation were not fixed, it seems reasonable to believe that it should have exhibited variations comparable to those variations of body, etc., mentioned above, in pigeons and chickens. Yet, if I read aright, there is not the slightest indication of any alteration in the incubation period of any of man's domesticated birds; on the contrary, all seem to adhere rightly to the ancestral characteristic as shown in congeners still wild, or in wild species most closely related. It has been definitely determined from the experience of hundreds of poultry raisers, in natural and artificial incubation, that the incubation period of the domestic hen is almost exactly and almost invariably twenty-one days: it matters not what breed, bantam or brahma, nor however remote from, or near to, the ancestral jungle fowl, the period of incubation remains the same as that of the jungle fowl, viz., twenty-one days. The same may be said, in effect, of the turkey, quail, pheasant, canary. pigeon, duck, goose and, so far as the writer can learn, all other domesticated birds.

Furthermore, birds belonging to families having a fairly similar incubation periocl, $i$. $e$.. finches, all exhibit this uniformity, even though separated by large geographic 
spaces, and even possibly by geologic time-spaces; thus, the swallow and the finches of Australia still cleave to the ancestral period of their cousins of the North, and the English and New Zaaland gamnets have identical incubation periods.

Certainly the incubation length seems far more changeless, persistent and deep-rooted in nature than are other characteristics of birds, as, for example, the proventriculus mucosa of a gull (25). Furthermore, as has been suggested. it is not subject to selection by man, as are other characteristics, for while he has, in effect, changed a jungle fowl into a five-toed dorking, and a rock-pigeon into a fan-tail, still both of these species have retained their original lengths of incubation.

If the structure of the egg shell persistently tend to be characteristic, and remain the same with groups of birds, or with the species (110), why should not the far more important process of embryonic development, and its length, do likewise? While the immediately foregoing would seem to show the length of the period of incubation as a fixed characteristic, yet a superficial examination of a list of such periods leads one to believe that there is, in fact, considerable variability in the length of incubation of a given species, and unless one can learn if this be true or false, it were absolutely useless to attempt to draw conclusions from the facts published on incubation lengths, because, viewing these facts as evidence, they are in many parts hopelessly conflicting. I am convinced that most of such conflicts are to be explained by a careful study of the influences apparently affecting the true length of incubation, $i$. $e$., influences causing apperent variability in the true length of incubation.

Variability in the length of incubation may be true, that is, permanently lengthening. or actually shortening, the minimum number of days for successful hatching under optimum conditions, and apparent, shortening or lengthening by slowing of the embryonic development by errors of faulty time measurements.

True variability-The writer questions very much whether there be any decided true variability, $i$. e., a variability occurring when all necessary conditions are optimum. There is a small amount of experimental evidence at hand which shows conclusively that with the domestic hen it is possible, by suitable regulation of temperature conditions in an artificial incubator (33), to shorten the length of incubation a few hours only. This is well known to poultry raisers, who know also that the dividing line between successfully shortening the period and killing the embryo is exceedingly difficult to maintain, even impossible at times. All secondary influences which tend to induce this subtle influence of temperature increase, especially towards the 
end of incubation, may be considered as coming under this caption. Such conditions as are quoted in nearly every poultry raiser's manual can be mentioned here; an attentive, faithful setting hen may bring out a hatching of chicks in twenty days (3:3), and favorable weather and a suitable nest site (104) also tend to maintain optimum temperature conditions, with possibly a true, but very shight, shortening of the incubation period.

This true variability towards the side of shortening the period of incubation is probably in progress now, the world over, with many different species, especially the higher birds, and it will be taken up in greater detail later on.

A pparent variability - By apparent variability I would have understood all lengthening of the specific incubation period which is merely an addition to it of days of prolonged and retarded embryonic development caused by the various factors mentioned in this discussion, or seeming shortening or lengthening due to error of determination.

Apparent or false variability is, in the greatest number of cases, merely the result of cooling the egg during incubation, which slows down the developmental pace, or it may actually suspend it for a while; in fact, the developmental process "can be suspended and held in check for several days without destruction of the germ" (33). There can be no question as to the effect of cooling the eggs while they are being incubated, because it has been proven many times (by accident or design) with the domestic hen (33) that its period of incubation can, by such cooling, be extended to twenty-three or even twenty-four days. It is probable that eggs of the lower birds can be chilled a much longer period than can those of the higher species, without killing the embryo, a fact which probably helps to explain the seemingly great variability shown in the incubation records of, for example, the emu.

There are many ways by which this cooling action occurs: a restless, inattentive hen, a cold site for a nest, conditions preventing the eggs from receiving the necessary heat properly, as ton thick shells, or which permit too rapid radiation, as too thin shells, or a poorly constructed nest; eggs which are too small radiate their heat too quickly, on exposure, since they are relatively of larger surface area than are larger eggs; parents in ill health or badly nourished will not produce optimum temperature conditions.

It appears to me that all of the conditions which are outlined in this study, which apparently modify the true or specific length of incubation, should be taken into account. in the future in all field, incubator and zoologic park work, in order that their effects may be eliminated in an endeavor to determine with the greatest possible accuracy the true 
incubation period of our living bird species, especially since the opportunities for such study will grow, as time passes, fewer and fewer before the devastating onrush of civilization.

Some of these conditions as outlined above may never occur in nature, yet it is wise to bear them in mind, and to eliminate their effects when engaged in studying the incubation of any bird.

It seems clear that a definite and correct explanation of the factor or condition which determine the true length of incubation would long since have been reacherl, hat the data heen more abundant and more amenable to study and analysis.

Because of the several distorting influences outlined above, there have axisen a number of explanations as to what determines or fixes the length of the incubation period, explanations which are now in order for detailed consideration.

\section{Size of Bird}

Before reviewing the information bearing on this explanation of the controlling factor of inculation dintion, it becomes necessary to define "size of bird." An examination of the different uses of this expression by various authors sheds no light on exactly what it means with them, and also gives no indication that all such writers mean by it the same thing. One finds the following expressions in current use: " (length of inculation) in a gencral way is proportionate to the bird's size" (15) ; "(length of incubation) varies with the size and vitalitr of the hirel" (1.2) : "duration of incubation in general depends on height" of bird" (38) ; "according to the size of the bird the incubation period raries, short. of long. with humminghirts ten days, with ostrich fifty days" (9). "Size of bird" may mean its dimensions, or its bulk, or, by implication, its weight. It does not seem possible that past writers on this subject could have meant size as indicated by the usual linear measurements given in describing a bird, for these would lead into a maze of characters, $i$.e., length of neck, total length, length of hill, tail, leges or borly, or the standing height, which are extremely plastic and subject to such wicle variation as to make it inconceivable that such shifting characters could directly influence so deep-rooted and inelastic a character as the duration of incubation; in other words, that these rariable characters could he paralleled hy rariations in the almost changeless tme length of incubation.

As for bulk in a bird, one must first recall that it and the usual measurements do not necessarily go hand in hand.

*Meaning its stature. 
A good example that measurements are not of necessity indices of bulk is given by a comparison between the black vulture and the turkey buzzard, for the latter's measurements are greater than the former's, yet its bulk is less (100).

This point is mentioned as illustrating again how confusing would be bulk or measurements if considered as intimately related to, or strongly influencing, the length of incubation.

It seems to the writer that bodily bulk must have heen meant when the expression "size of bird" was used; bodily bulk and weight are closely related, but both vary more or less according to the bird's age, the sex, the season of the year and the abundance of food, etc., etc.

The sequence of the steps of derelopment in bird embryos being practically the same in all birds. it would seem reasonable to believe that the larger the bulk to be grown, the longer it should take to complete its evolution. However, it is not alone the differing bulk to be produced which may help to bring about varying incubation periods, but also the fact that many of these steps of development in different species are greatly abbreviated or jumped almost completely; hence, one can say that it is the speed and duration of the different steps in embryonic development which produces differences in the lengths of incubation.

It is quite patent that, in a general way, there is a relation between the size (or bulk) of a bird and the duration of its incubation period, yet there are so many striking exceptions that one, at best, must hold it to be only a loose and rather inclefinite correlation, and probably not a relation of cause and effect, but rather an example of two effects influenced by a single underlying cause, a suggestion to be more fully elaborated later on.

Using the words "size of bird" in the rather indefinite way found in most writings, one finds some interesting conditions in its relation to the length of incubation, having in mind the prevailing notion that the larger is the bird, the longer is its period of incubation.

Notice the difference in the sizes (or bulks) of the following pairs of species, each pair being recorded as having similar incubation periods: great-tailed grackle and tree crecper, (hipping sparrow and evening grosheak, golden eagle and pultin, ostrich and liwi. If bulk or size alone counted with these species as the controlling factor determining the length of incubation, there should be noticeable differences in the incubation periods of these birds, rather than a definite similarity, as is the case. On the other hand, it is not uncommon to find a decidedly smaller bird having a longer incubation than is found with a decidedly larger 
bird, as, for example, is found with the lapwing and the domestic hen, or the killdeer and the hen.

If size or bulk controlled the length of incubation, the hen should have a much longer period of incubation than that of the lapwing or killdeer, which, however, is not the case. The domestic hen is much larger than any of the following species, lorikeet, pied-billed grebe and common tern, yet all have almost identical incubation periods.

Many birds are quite alike in size, yet exhibit marked differences in their respective incubation lengths, $i$. e., meadowlark and upland plover, kiwi and domestic hen. The swift and the raven are recorded as having practically the same incubation period. ret how great is the disparity of their sizes! This loose relation of size of bird and length of incubation is more noticeable within the confines of natural groups (families), the Buteonidae for example, a fact which was pointed out by $H$. Milne-Edwards (38) as long ago as 1863, and recently Cole and Kirkpatrick (92) intimated their belief in such a relation in the pigeon family.

While it is true that this connection between bulk and incubation length is strikingly evident in some families, the contrary obtains in many others. so that one can hardly consider it a law. The lapwing is smaller than the wood-cock, but has a longer incubation period, and with the Laridae it is found that the sooty tern and the herring gull have similar incubation periods, yet are markedly different in size.

The body of at least one species of the Megapodidae is about the size of a domestic hen, yet this species' incubation period is twice as long as that of the hen. What shall one say of the several races of song sparrows, with their marked variations in size, and the incubation period of this species (including the subspeciess)? It is highly improbable that the differences in these sizes are paralleled by differences in the incubation lengths.

It is impossible to explain or understand the situation which arises in considering the record of the lammergeier, the incubation period of which is given as twenty days: this species is larger than the golden eagle (150). and its short incubation period (as recorded) is inexplicable under any given theory (past or present), and the writer believes the record is incorrect.

It would seem from the above examples that there is too much lack of concordance between the bird's bulk and its incubation period to admit a controlling relation of the first over the second, even admitting that there is a loose relation between the two.

If now one assumes that by size of bird is meant weight, one has a more stable standard to go by, especially if one assume certain criteria as necessary in taking the weight. 
First, shall it be the male's or the female's reight? This is decidedly important, for there is a great difference in the weights of the two sexes with many birds-it may be $20 \%$ in the ostrich, and the male prairie falcon's weight is but $331-3 \%$ as much as its mate; and the female European sparrow hawk (Accipiter nisus) is said to weigh, at times, twice as much as its mate (181). Secondly, it is necessary to take a season which may possibly have the greatest influence, if any, over the length of incubation, $i . e$. , the breeding season. for it will probably be found that a bird's weight follows most closely a normal at this time of the bird's physiological rear, and hence be less fluctuating and more influential.

If now one tries to study a comparison between birds' weights and the duration of their incubation periods, there arises at once an awkward obstacle, namely, a ridiculous paucity of data on bird weights. The following list gives all the records of bird weights which have come to light in the prosecution of this study, plus those determined by the writer.

TABLE NO. 3

Weights of Birds in Ounces Avoirdupois

Weight Authority

Ostrich \&...................... avg. 4000.00 141

Kiwi .................... 64.00 42

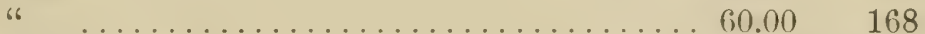

Emperor Penguin................. $1440.00 \quad 20$

Adelie Penguin ................... 42.50 20

Albatross ..................... 2.24-288.00 185

Yellow-billed Tropic Bird............. 14.00 26

Pelican (Pelicanus mitratus) .......... 512.00 181

White Pelican ô, Juv. October......... 240.00 78

Great Blue Heron................. 96-128 180

Heron (Ardea cinerea)..............6.64.00 181

Wood Ibis ..................... 144-192 180

Domestic Duck (Rouen) ㅇ............ $128.00 \quad 34$

Shoveller Duck — o - May 11............ 17.25 78

Grey Wild Geese …............. $160.00 \quad 34$

Greater Snow Goose.............. 80-104.00 180

Canada Goose ..................128-224.00 180

Brant ............................ 64.00 180

Whistling Swan .................. 192-304 180

California Vulture ................avg. $320.00 \quad 100$

Gyrfalcon (Falco rusticola gyrfalco) ...... 84.00 180

Prairie Falcon 9 .................... 72.00 145

" " "

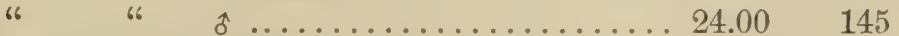

Western Sparrow Hawk of July.......... $4.76 \quad 78$ 
Weight Authority

European Sparrow Hawk. .......... 5.00-6.00 181

Eastern Sparrow Hawk................ 4.00 . 180

Honey Eater (Parnis apivorus) .......... 32.00 181

American Goshawk ................... 47.00 157

Hen Harrier (Circus cyaneus) . . . . . . 12.00-13.00 181

Western Red-tail Hawl o . . . . . . . . . . . . 64.00 145

Buzzard (Buteo asiaticus) .......... 32.00-40.00 181

Western Red-tail Hawk, June............ 39.50 78

Red-shouldered Hawk .................32-48.00 180

Swainson's Hawk o . . . . . . . . . . . . . . 56.00 145

" " $6 \quad \ldots \ldots \ldots \ldots \ldots \ldots .25 .90-56.00 \quad 180$

" " "

" " $\quad$ क April............. 39.00 78

American Rough-leg Hawk, Jan........ $30.37 \quad 175$

" " "Dec........... 33.65 78

Golden Eagle.................... $184.00 \quad 60$

" " $\ldots \ldots \ldots \ldots \ldots \ldots \ldots \ldots \ldots$. $160-192.00 \quad 180$

Bald Eagle....................... $184.00 \quad 60$

" " $\quad \ldots \ldots \ldots \ldots \ldots \ldots \ldots \ldots . \ldots 128-192.00 \quad 180$

Globose Currasow o Feb............. 114.00 169

Bobwhite ................. 5.50-6.50 46

Scaled Quail o Jan.................. $7.00 \quad 78$

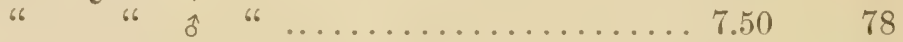

Grey Partridge................ 12.00-13.00 46

Capercaille ${ }^{3}$..................... $184.00 \quad 135$

Dusky Grouse . . . . . . . . . . . . . . 4 40.00-56.00 48

Ruffed Grouse................. 30.00-40.00 46

" " (Bonasa umbellus

umbellus) ...... 18.00-24.00 180

Sage Grouse 8 ...................... $128.00 \quad 48$

Wild Turkey o. ........................ $160.00 \quad 78$

" " $\quad$ "............ 160.00-288.00 49

Guinea Fowl \&....................... $56.00 \quad 78$

Ring-neck Pheasant $+\ldots . . . \ldots \ldots$. avg. 3. 36.00 108

Golden Pheasant o. . . . . . . . . . 20.00-24.00 108

Domestic Hen (mixed breed)....... 64.00-80.00 78

American Coot (Fulica americana) ... 16.00-20.00 180

Great Bustard ....................4 480.00 10

Wilson Phalarope o May 11.........avg. 3, $2.34 \quad 78$

European Woodcock

(Scolopax rusticola) \& ...........8.00-27.00 181

American Woodcock ..............6.6. 95

" " $\quad$ "

"6 " 6 6.............6. $6.00-9.00 \quad 180$

Wilson's Snipe ................ 4.00-5.00 180

Common Snipe (Gallinago crelestis) ... . 3.00-8.00 181

Solitary Snipe (Gallinago solitaria) ... $7.50-10.00 \quad 181$ 
Swinhoe's Snipe (Gallinago megala) ... . 6.00-8.00 181

Jack Snipe (Gallinago gallinula) . . . . . . . 2.00 181

Greater Yellow-legs ............. 6.00-10.00 180

Lesser " " ............. 3.50-5.00 180

Spotted Sandpiper (Actitis macularia) ㅇ May..1.53 is

Curlew (Numenius lineatus) ..........12.00-14.00 181

Killdeer o Julv.................... 3.10 Ts

Kumlien Gull (Larus kumlieni) .......... 21.00 180

Lesser Tern (Sterna minuta) ............ 2.00 181

Band-tail Pigeon .....................avg. $12.00 \quad 12 \tau$

Domestic Pigeon .................. $10.00 \quad 78$

Passenger " " (Estopistis migratorius)... $12.00 \quad 150$

Mourning Dove ........................ 4.50 isg.

" " $\quad \ldots \ldots \ldots \ldots \ldots \ldots \ldots \ldots .5 .0 .60 .6 .00 \quad 180$

Roadrunner $\hat{o}$ in October............. 11.00 is

Cockatoo Parakeet .................2.88 152

White Cockaton ................. 21.25 15.2

Great Sulphur Crested Cockatoo..... 26.62-43.62 152

Lesser Sulphur Crested Cockatoo......... 12.25 152

Bare-eyed Cockatoo (Cocatua gymnopis) ... 19.25 152

Moluccil Cockaton .................... 34.12 152

Leadbeater's Cockatoo ................ $14.50 \quad 152$

Rose-breasted Cockatoo ............... 18.75 152

Blue and Yellow Macaw............. $37.00 \quad 152$

Great Blue and Yellow Macaw......... 51.75 1.52

Midget Macaw (Ara severa) . . . . . . . . . . 10.12 152

Elegant Grass Parrakeet............... $3.62 \quad 152$

Alexandrine Parrakeet (Paliornis torquata) . 8.50 15.2

Belted Kingfisher.................. 5.00-6.00 180

Long-eared Owl, April.................... 11.28 is

Barred Owl.................. 20.00-32.00 180

Screech Owl (Otus asio asio) ........ 4.00-6.00 180

Eagle Owl (Bubo maximus) ............ $112.00 \quad 181$

Great Horned Owl.................. $56.00 \quad 145$

" 6 " (Bubo virginianus virginianus) ... 48.00-72.00 180

Burrowing Owl, May................. 5.84 78

Western Nighthawli ô June........... 2.75 78

Sennett's Nighthawk $9 \ldots \ldots \ldots \ldots \ldots .2 .25-3.35 \quad 177$

Pacific Nighthawk o............... 4.00 177

Broad-tailed Hummingbird ô July........... 10 78

Rocky Mountain Hairy Woodpecker o ..... 2.25 78

Hairy Woodpecker (Dryobates villosus villosus) ........................ $3.00 \quad 180$

Downey Woodpecker (Dryobates pubescens medianus) .......................... $1.50 \quad 180$

Williamson's Sapsucker o April 8th....... $1.62 \quad 78$

Red-headed Woodpecker of July.......... 2.80 78 
Ant-eating Woodpecker $\hat{\alpha}$ in October....... $2.75 \quad 78$

Lewis Woodpecker of Aug............. 3.81 78

Western Flicker of Aug............... $4.30 \quad 78$

Kingbird $\delta$ July.................. $1.60 \quad 78$

Arkansas Kingbird 우 July............. $1.60 \quad 78$

Say's Phoebe ơ June................. .91 78

Hammond's Flycatcher ô.July........... .40 $40 \quad 78$

Horned Lark (Desert), Nov.............. $1.18 \quad 78$

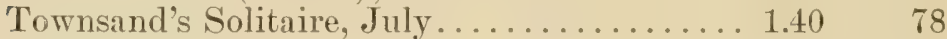

Western Robin $q . J$ une................ $3.35 \quad 78$

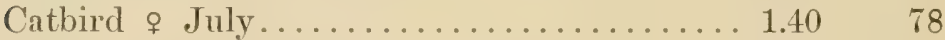

Water Ousle, July................. 2.30 78

Bohemian Waxwing $q$ avg. 11, Feb........ 2.21 175

Rock IVren ô avg. 11, Feb........ 2.22, 175

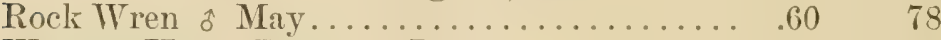

Western House Wren $q$.June............ .50 .58

White-rumped Shrike of June........... 2.03 78

Cassin's Vireo, July.................. .60 . . . . . . . . . . . 78

Warbling Vireo, Jily ................ .46 46

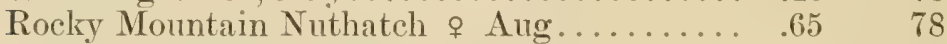

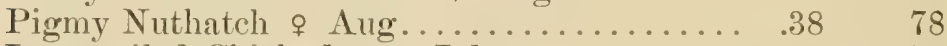

Long-tailed Chickadee of July........... .40 48

Magpie, May . . . . . . . . . . . . . . . . 5.34 78

Long-crested Jay, July................ $4.00 \quad 78$

Rocky Mountain Creeper o July......... .20 2078

Orange-crowned Warbler o May....................... 182

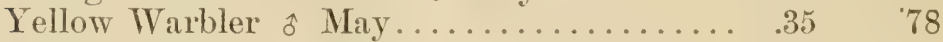

Myrtle Warbler ô May............... .50 182

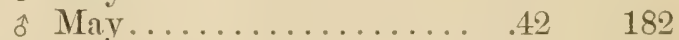

Audubon's Warbler ô May............. .40 182

Macgillivary's Warbler of July......... .40 78

Western Tanager ô July................10 1.10 78

Red-ringed Blackbird o (Thick-bill). June. . 1.60 78

Red-wing Blackbird (Agelaius phœniceus phoniceus) ..................2. 2.50-3.00 180

Meadow Lark (Sturnella magna magna) $4.00-5.00 \quad 180$ " 6 (Western) (Sturnella neglecta),

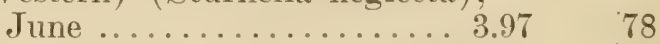

Rusty Blackbird ............... 2.00-2.50 180

Brewer's Blackbird o June............ 2.60 78

Bronzed Grackle, May 10............. $3.87 \quad 182$

House Finch o May.................. . . 66 78

Arkansas Goldfinch $q$ July ............ $.47 \quad 78$

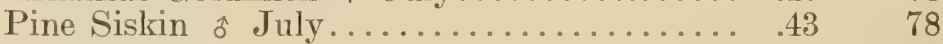

English Sparrow o............................... 1.05 78

Western Vesper Sparrow of Oct.................... 78

"6 "6 o Apr. $24 \ldots \ldots \ldots 1.00 \quad 78$

Lark Sparrow ㅇ.................... $95 \quad 78$ 
Red-backed Junco of July.............. .70 78

Cassin's Sparrow ô July................70 78

Western Song Sparrow ô Feb. 28.......... .88 175

" Tree "

" " " 6 o avg. 3, Feb. 28... $.71 \quad 175$

Spurred Towhee of June.............. 1.50 78

Black-headed Grosbeak of June........... $1.30 \quad 78$

Lark Bunting of June............... $1.50 \quad 78$

It will be necessary here to consider but a few comparisons of different species and their weights and lengths of incubation; the ostrich, kiwi and emperor penguin have identical incubation periods, yet their weights are two hundred fifty, four, and ninety pounds, respectively; the domestic goose and the sparrow hawk have nearly similar incubation lengths, ret the first weighs ten pounds, while the second but five (more or less) ounces; the ruby-throated hummingbird and Cassin's vireo incubate their eggs almost exactly the same length of time, yet one weighs one-tenth of an ounce and the other six-tenths of an ounce. These examples form comparisons between species of different families, where one can expect such lack of parallelism between weights and incubation periods. With species within the confines of a single family. howerer, equally sharp lack of correlation of weights and incubation lengtlis occur: the bobwhite and the grey partridge have similar incubation periods, yet their weights are as five and one-half is to twelve. and there are several species in Fringilline birds which have identical incubation lengths, but differ markedly in weight.

While the available data on bird weights is deplorably insignificant, when the species involved are compared to the total number of known birds, yet it would seem reasonable to expect more indications of a relation of weight to incubation length, if the weight fixed this length, than one finds in the data at hand. I feel that whatever relationship appears in these curves of weight is not one of cause and effect, but, as has been said before. a correlation of two effects to a third factor as an underlying single cause. The singular and suggestive fact in this phase of our question is that with man's domesticated birds with which one can see a variation of, at times, several hundred per cent. in weight, there should be no corresponding change in incubation.

It is highly desirable to have more recorded weights of birds, especially of the breeding female, since biologic characters of birds will be more and more called upon to aid in the future in solving many riddles in avian physiology. Until a much larger mass of data along these particular 
lines has been accumulated, one must suspend final judgment on the question of how much does a bird's weight or size influence its incubation length.

\section{Age of Female}

It is well known that pullets of our barnyard fowl lay eggs averaging smaller in size than does the mature hen, and this condition also holds good with pheasant pullets: poultry men know that eggs of mean size and weight from each race of our domestic hen hatch more successfully than do too large or too small engs. whence it might he held that the age of the female may affect the length of incubation, since it has been shown that the mature hen is apt to lay eggs near the normal for her race, which are more uniformly successful in hatching. Whether or not the larger or the smaller than normal eges really hatch later or earlier than the average I do not know; in the absence of definite data in answer to this, the question must be left open and undecided. Possibly the age of the female really affects the fertility or viability of the egg, and not the incubation length. It is also possible that very old females may exhibit a tendency to a slowing of metabolic intensity, which would unfarorably affect the incubating temperature.

\section{Condition of Parents}

It is not possible to say, owing to the lack of exact information, if the physical condition of the male has any influence on the length of incubation with the species with which the female does all of the incubating; nevertheless, it is conceivable that old. or immature. or weak males may give the new individual in the egg a poor start, entailing perhalps a slower rate of development. resulting in a longer period of incubation.

There is no doubt in my mind but that poor health in either parent (when both incubate) would result in what amounts to a cooling of the eggs during incubation, and a resulting apparent lengthening of this period. through sluggish embryonic derelopment. all becalse of the setting bird's temperature being lower than normal. While several writers mention the physical condition of the parents as being a factor in affecting the length of incubation, none has given any data. experimental or otherwise, in support of the suggestion. It must be left open and undecided.

\section{Conduct of Parents}

The assiduity (or neglect) of the incubating parents in covering their egres unquestionably results in the eggs being hatched "on time," or "late," or "not at all." In other words, the length of incubation is unquestionably affected by the incubating bird being frightened from its nest too 
frequently, or kept from its nest too long, or through the parent birds being inattentive.

This effect on incubation has long been known to poultry raisers; it is, however, an effect not altering the true length of incubation, but merely one of cooling and retardation of embryonic development. Such conduct of parents does not affect the true or specific incubation length.

\section{Longevity}

In a valuable paper on longevity in birds, Gurney (132) suggested that there might be some relation between bird longevity and the length of incubation.

It is nearly impossible to reach any definite conclusion on this suggestion since very little is known on that variety of longerity which is most likely the only one which alfects the fluctuations of bird population and their correlated biologic results. There are nearly a hundred records relating to the ages to which various species of birds live in captivity or when domesticated, but this is potential longevity. What is lacking, however, is information on the mean or average longevity, the length of life which birds attain in nature, under normal conditions of life's pressure for and against them. Brehm (132) thought that longerity was more or less correlated with size, and there are some indications that within the Class this is true, but it fails to hold good when comparing species of differing Classes.

A curve was plotted from the longevity data given by Gurney and gathered by the writer from other sources and placed in juxtaposition with the curve of incubation lengthe of the same species; it showed no correlation between the two. It is safe, from the present data, to hold that length of incubation and longevity have no relation in fact, a conclusion which $H$. Milne-Edwards (13:3) reached many yeare ago.

\section{State of Young at Hatching}

\section{Precocious,}

Altricial,

Completeness of development.

In these three conditions, given as determining factors affecting the length of incubation, there are more or less confused, it seems to me, tro distinct ideas; the first is that of precocity in its usual sense, i.e., the state of self-helpful activity and semi-independence of young birds at hatching; and the second is that of the condition of the young being well on towards completeness of development at hatching. The first conception may or may not include the second, while the second always includes the first - a newly hatched duckling is typical of the first, while a newly hatched megapod bird is typical of the second. In considering precocity 
it is easiest to handle the idea at the same time with altricial conditions of the young.

Precocity and altricial characters are antipodal, and if precocity confers (or engenders) a long incubation period, it seems reasonable to expect that an altricial species should have a short period. This expectation is realized in a number of instances, the ostrich and the English sparrow being good examples. There are, however, many striking exceptions; the domestic hen and many parrots have identical incubation periods; one is typically precocious and the other is highly altricial; and yet under this explanation the first should have a long period and the second a shorter one. Most, if not all, of the Charadriidae are precocious, which ought to bring about with these species uniformly long incubation periods, yet the records clearly show a great variety of lengths of incubation with this family, just about as one would find it in any other fairly large and diversified natural group, i.e., from sixteen to thirty days. Burns (3) justly calls attention to the lack of definite relation between precocity and long incubations, and altricial character's and short inculbations, comparing with this in mind, ducks and large hawks, chats and sandpipers, tropic birds and gulls, all examples which in his belief disprove the correctness of the suggestion of a causal relation between precocious and altricial characters and the duration of incubation. If precociousness engendered long incubation periods, a majority of the so-called precoces should have this type of incubation length. Now, if one examine the records of the lengths of incubation amongst the precocious Ratitae, Crypturidae, Phasianidae, Anatidae and others, one finds the incubation length varying from fourteen to fifty-eight days. In other words, with the socalled precoces one finds a wide range of variation in the length of incubation, just as one would find with almost any other group of orders and families indiscriminately mixed together. The supposed correlation of precocity and long incubation may have arisen through a belief that the precocious birds laid large eggs, and that large eggs presuppose long incubations. but large eggs are by no means the rule with the prococes, as is witnessed with the quail, hen, grouse, etc. Furthermore, this does not help this assumed explanation since, it will be shown later, the length of incubation is not closely correlated to the size of the egg.

More or less relevant to this phase of our problem is Gadow's (150) belief that there is a direct relation between the length of incubation and the nesting period. He assumes that the developmental period is made of two portions, embryonic and post-embryonic, and that the nest period covers the post-embryonic developmental stage, which is by 
no means a safe assumption, since many altricial birds, and practically all the prococes, continue post-embryonic development for a good while after leaving the nest.

Gadow's conclusion is that a long nest period is preceded by a short incubation period and (inferentially) vice versa.

While the incubation and nesting periods of some birds support this view, there is also much evidence against it. The screamer and the noddy tern do not bear support to the idea. The secretary bird is reported to incubate fortytwo days, yet its young do not leave the nest for six months after hatching (138), and the condor incubates fifty-six days, while its young are reported to live seven months in the nest after being hatched (154). This question can be examined in another way by making a ratio of incubation length and nest life, counting the latter with precocious birds as zero. The following list gives this ratio with a few species: Domestic hen, $21 ; 0$; house-finch, $14 ; 14$; sparrow hawk. $29: 29$ : golden eagle, 30 :35; yellow-headed tropic bird, $28 ; 62$. It seems to me that while there is much color of truth in this suggestion made by Gadow, whose eminence in zoologic work compels attention to his ideas, there is so much against the theory that judgment must still be withheld on its finality.

Under the second way of putting the explanation comes Arrigoni's (12) statement, which voices also that of Newton (25), Evans (1-2), and Claus (10). Arrigoni writes: "The period of incubation varies, and is in relation with the state of perfection in which the young are born." It is true that the young of the precoces are physiologically more perfect than are the young of altricial birds, but both are far from being morphologically perfect, and all have a long way to go before becoming so. An English sparrow's nestling is typically the opposite of precocious, yet it hatches out in fourteen days, and spends but fourteen days in the nest. I doubt if a young killdeer reaches an equal level of development in fourteen days after hatching. As a matter of fact, it takes three weeks (after hatching) for young killdeers to reach a stage of growth permitting them to follow the parents on the wing; it is ten days (after hatching) before they are able to lift their bodies off the ground with their wings alone (183).

The only birds known to the writer whose young are hatched in a condition approaching "perfection" are the megapodes, and, the writer hopes to show later on. the length of incubation with these birds is not correlated with the state of perfection at hatching alone, but rather with quite another characteristic. 
Precocity seems to me to be an acquired character of expediency, found in a heterogeneous mixture of species. To many, precocity is synonymous with "lowness," and is said to be a retained reptilian characteristic, the nearer a bird to its proto-reptilian ancestor, the greater its precocity. By this token the low birds should have both long incubation periods and noticeable precocity. However, there are quite a few "low" birds which are the reverse of precocious; they are definitely altricial, $e . g \cdot$, pelicans, water turkeys and cormorants (65). Preraft (115) puts the facts much more clearly, and with greater truth, when he says, "When the nestling is active from the moment of hatching, the eggs have a relatively longer incubation period than in cases where the nestlings are for a long time helpless."

The writer feels justified in holding with Burns (3) that the possession of precocious or altricial characters does not confer thereby long or short incubation periods, and that they are not correlated to the length of inculation as causes to effects.

$$
\text { Size of } E g g
$$

Claus (10), Fürbinger (102), and Chapman (65) all state that the incubation period varies with the size of the egg. Burns (3) says it "seems to depend almost altogether on mere size or bulk" of egg, while Evans (2) in his second conclusion feels willing to hold "that within each group, the larger the egg, the longer the period."

What is meant by "size of egg."? It does not seem possible that these (and other) writers mean mere size as expressed by length and breadth, for these two dimensions cannot possibly account for, and produce, the endless variations in the shape of eggs, variations of shape which produce corresponding differences in bulk, nor does it seem possible that they believe the infinity of bulks produced by these differences in shape would be paralleled by corresponding alterations in the incubation period. If there be any relation between the size of the exge and the duration of its incubation, the writer feels that the term "size" should be taken to mean weight, for after all is said, these differences in measurements and shape result in corresponding variations in egg weight. If all birds' eggs were of the same specific gravity, and if there were a fixed relation between the length-breadth index and the weight, one condel easily ascertain the weights of a large number of different birds' eggs, since there is an enormous accumulation of lengthbreadth measurements at hand, collected with infinite care, toil and patience for rears by ornithologists all orer the world. Unfortunately 'I was able to find no data available from which one can learn if all birds' eggs have similar specific gravities, though Spohn and Riddle (173) make 
statements which seem to indicate that the specific gravities of eggs from differing species are dissimilar; and unfortunately, also, the length-breadth index bears no relation to the egg weight (140). The writer studied this question for some time, seeking to evolve a formula whence one could get the egg weight from its length-breadth index, but found it impossible of achierement, in which fincling he is supported by Curtis (140), who says, "The shape of the egg (hen's), as measured by the length-breadth index, is negatively correlated with the weight of the egg and with the weight of each of the egg parts."

It therefore seems to me that the only datum to be used in considering this phase of the problem in hand is, perforce, the weight of the fresh egg, and the relation of the egg weight to the length of incubation will be taken up a little later on in this section, while it will be expectient now to consider, more or less carefully, the relation of mere bigness to the incubation length.

It is quite apparent, after a careful review of the facts, that there is a loose relation between the size of the bird and its egg; the smaller the bird, the smaller the ege, glaring exceptions noted. This parallelism is more noticeable within the confines of natural groups (families), and within these groups there is also a loose relation between the size of the egg and the duration of incubation, $i . e$. , the larger the egg (and the bird), the longer the incubation, a relation well illustrated by the Buteoniclae. There are, howerer, families wherein this relation does not hold good, or wherein the exceptions are too noticeable to be disregardecl. Thus the egg of the guinea hen is decidedly smaller than that of the domestic hen (51), yet the guinea hen has the longer incubation period: on the other hand an exmmple is fomnd, in the same family, where the larger egg is accompanied by the longer incubation period, $i . e$, with the Mikado pheasant as compared with other pheasants. There is, relatively, an enormous variation in the sizes of the eggs of fringilline birds, but the great majority of this family conform more or less closely to the fourteen-day period. There are so many contradicting facts in relation to this theory that one seems impelled to believe that egg size is not a factor in determining the true length of incubation; the size of eggs varies often to a great degree in a single set. and erges in different sets from individuals of one species difler much in size; the average measurements of eggs from the same species in different regions vary. $i . e$. those of the Mikarlo pheasant (68). Nevertheless, all these variations are unaccompanied by corresponding differences in the lengths of incubation. A fact of great weight in this discussion of egg size and incubation is that, not withstanding the remarkable 
variations in the size of the eggs of the domestic hen and its dilferent races, there is no corresponding variation in the incubation period, be the egg from a bantam or a shanghai; in other words, the jungle fowl and its bizarre descendants all retain the ancestral length of incubation, viz., twenty-one days. It seems to the writer that if this length were plastic, and altered hand in hand with changes in the size of the egg, it should be strikingly apparent with the domesticated bird, especially the common barnyard fowl, yet, as a matter of fact, there is, to reiterate, not only no change to be noticed, but a tenacious retention of the prinitive ancestral cluration of incubation.

Poultry raisers (103) have long recognized several different factors which produce large variations in the size of hens' eggs, and these factors have been given by Curtis (140). as follows: Age of hen, season of laying. state of health of hen, position of egg in the egg laying period (i.e., the first or the last egg laid), the rate of egg production, and lastly the food consumption of the hen. It is possible that some of these factors can have no existence with birds in the wild state, yet, on the other hand, some appear to exist with birds in natural conditions, and still seem unaccompanied by parallel changes in the length of incubation.

If egg size (indicated by measurements) be examined as to its relation to the length of incubation, one finds a complicated condition of affairs. Newton (25) says that the eggs of the guillemot (A. troile) are ten times the size of those of the raven, yet the incubation periods of these birds are but three to one, while the eggs of the eagle (sp?) and those of the guillemot are recorded (25) as being almost the same in size, but there is a difference of four or six days in the lengths of incubation of these two species. 'The incibation periods of the elf owl and of several hummingbirds are similar, yet there is a large difference in the sizes of their respective eggs. The eggs of the flamingo and some megapods are nearly alike in length and breadth. nerertheless the first incubates twenty-eight days and the second forty-two days, rather than being identical, as would happen were this egg-size control theory correct.

The above are all examples from species belonging to different families, and as Evans has stated, there is not much relation between $\mathrm{egg}$ size and the length of incubation outside of the boundaries of natural groups (families). 'There are, however, numerous exceptions also to be found within families.

The eggs of the white and the brown pelican are recorded as differing noticeably in size, but both species have the same duration of incubation. Furthermore, eggs laid by 
white herons (138) in Europe are much larger than eggs laid by the same species in India, withont, so far as the writer can learn, any difference in the incubation periods of the European and the Indian birds.

It is self-evident that size, when determined by linear measurements, is an exceedingly shifting datum on which to base comparisons of different incubation periods. If there be any relation between these periods and the egg size or bulk, it seems important to secure a better datum than the above, and in a fresh egg's weight, the writer believes, one has a datum beyond criticism, as to its meaning, and one which is unaccompanied by any questionable secondary considerations, and hence furnishes much more secure ground on which to build comparisons, and from which to draw conclusions.

Unfortunately, the number of recorded egr weights from different species, gathered by the writer for this study, is very small, though there are, doubtless, many others tucked away in inaccessible publications; the following list (Talble No, t) gives all those fouml in literature. by the writer, plus a few which were determined by him personally. An additional list (Table No. 5), is given of the weights of individual eggs occurring in sets. All weights are in onnees and pounds (avoirdupois). and. so far as known, are of fresh eggs, unless otherwise specified:

\section{TABLE NO. 4}

\section{Weights of Bird Eggs in Ounces Avoirdupois}

Ostrich ... 48,00-6000 Auth 10

Ostrich ......................... avg. $60.00 \quad 141$

Emu ........................... 20.00 10

Kiwi ..................... 14.00-20.00 10

Kiwi .................... 14.00-15.00 42

Kiwi ............................. 14.00 168

Emperor Penguin.................... $16.00 \quad 20$

Adelie Penguin.....................4.80 136

Adelie Penguin...................... $4.56 \quad 20$

Yellow-headed Tropic Bird............. $1.42 \quad 26$

Loon (Sp?) .......................... 4, 5.67 178

Black-crown Night Heron......... avg. 4 sets, 1.25 178

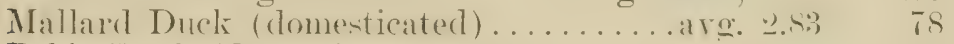

Pekin Duck (domesticated) . . . . . . . . 2.38-3.00 78

Goose (toulouse)........................ $6.00 \quad 78$

California Vulture (estimated by IV.H. B.) 10.9010

Sparrow Hawk....................50 56

Western Red-tail Hawk. ................ 2.10 78

Mallee Fowl (Lipoa ocellata) . ............ $6.50 \quad 186$

Globose Curassow. . . . . . . . . . . . . . . . . . $8.00 \quad 169$

Domestic Turkey.................... avg. $3.23 \quad 78$ 
Weight Authority

Guinea Hen.................... $1.40 \quad 78$

Guinea Hen..................... $1.40 \quad 51$

Silver Pheasant.................... . $1.50 \quad 109$

Ring-neck Pheasant. . . . . . . . . . . . avg. 1.20 10 9

Golden Pheasant...................... $1.00 \quad 109$

Reeves Pheasant.................... .98 109

Domestic Hen..................... $1.90 \quad 78$

Domestic Hen..................... $2.00 \quad 51$

Killdeer ......................... $40 \quad 78$

Mountain Plover ....................... 3, .52 182

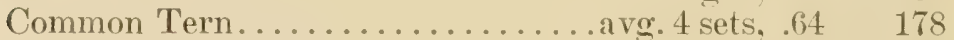

Domestic Pigeon.................... .50 . 78

Mourning Dove..................... .40 48

Kingfisher (Ceryle alcyon) ............ avg. 3, .45 178

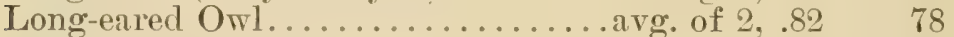

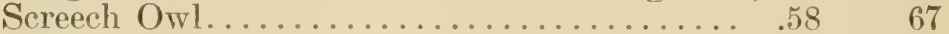

Western Nighthawk................. .35 78

Broad-tailed Hummingbird..............vvg. $.02 \quad 78$

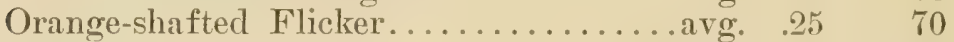

Kingbird ............................ 4, 178

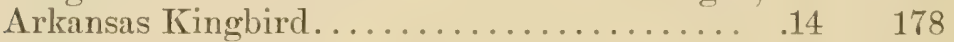

Veery ............................... 4, 10178

Eastern Robin.................... avg.4,.06 178

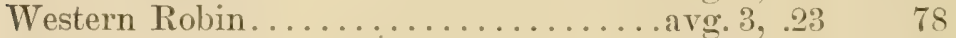

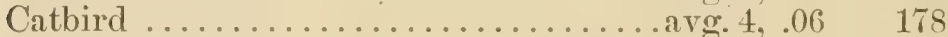

Barn Swallow............................ of 2 sets, .05 178

Bank Swallow............... avg. of 4 sets, .05 178

Tree Swallow.....................avo. 4,.06 178

Cliff Swallow............... avg. of 3 sets, .07 178

Red-eye Vireo................ avg. of 2 sets, .07 178

Magpie ............................... $34 \quad 78$

Crow (Corvus brachyrhynchos brachyrhynchos

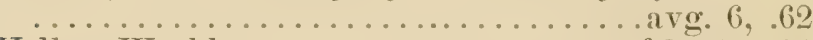

Yellow Warbler............... avg. of 2 sets, .0t

Ovenbird ............................... 4, .09

Redstart ................................ 8, .05

Bobolink .......................avg. 5, .10

Western Meadow Lark..............avg. 3, .20

Brewer's Blackbird.................. avg. 6, .18

House Finch..................... avg. 8, .08

English Sparrow.................. avg. 10, .09

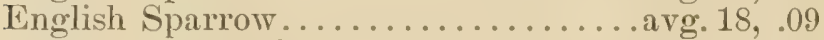

IVestern Vesper Sparrow..............avg.4, .09

Chipping Sparrow............. avg. of 2 sets, .05

Song Sparrow (subsp?) ..............avg. 14, .07

Black-head Grosbeak................avg. 3, .10

Lazuli Bunting. . . . . . . . . . . . . . . . . . . . . . . . .

Lark Bunting.................... avg. 4, .10 
TABLE NO. 5 (78)

Weights of Eggs in Sets, in Grains

\begin{tabular}{|c|c|c|c|c|c|c|c|c|}
\hline & \multirow[t]{2}{*}{ Set } & \multicolumn{7}{|c|}{ Egg Number } \\
\hline & & 1 & 2 & 3 & 4 & 5 & 6 & 7 \\
\hline Killdeer $\ldots \ldots \ldots \ldots \ldots \ldots \ldots \ldots$ & $\begin{array}{l}1 \\
2\end{array}$ & $\begin{array}{l}175 \\
221\end{array}$ & $\begin{array}{l}190 \\
214\end{array}$ & $\begin{array}{l}186 \\
215\end{array}$ & $\begin{array}{l}198 \\
229\end{array}$ & $\cdots$ & $\ldots$ & $\ldots$ \\
\hline Nighthawk (Western) (Sup sp?).. & & 140 & 128 & $\cdots$ & $\ldots$ & $\ldots$ & .. & . . \\
\hline Broad-tail Hummingbird.......... & $\begin{array}{l}1 \\
2 \\
\end{array}$ & $\begin{array}{l}8 \\
8\end{array}$ & $\begin{array}{r}9 \\
\ldots \\
\end{array}$ & $\cdots$ & $\ldots$ & $\ldots$ & $\begin{array}{l}\ldots \\
\cdots \\
\cdots\end{array}$ & $\ldots$ \\
\hline Arlsansas Fingbird . . . . . . . . . . & $\cdots$ & 59 & 70 & 60 & 66 & $\cdots$ & $\cdots$ & $\cdots$ \\
\hline Western Robin................ & $\cdots$ & 109 & 105 & 109 & $\cdots$ & $\cdots$ & $\cdots$ & $\cdots$ \\
\hline Magnie .................. & $\begin{array}{l}1 \\
2 \\
\end{array}$ & \begin{tabular}{|l|}
140 \\
132 \\
\end{tabular} & $\begin{array}{l}140 \\
140 \\
\end{array}$ & $\begin{array}{l}14 \frac{1}{2} \\
144 \\
\end{array}$ & $\begin{array}{l}140 \\
152 \\
\end{array}$ & $\begin{array}{l}144 \\
155 \\
\end{array}$ & $\begin{array}{l}144 \\
152 \\
\end{array}$ & $\dot{1} \dot{5} \dot{z}$ \\
\hline Western Meadow Lark.......... & $\cdots$ & 83 & 87 & 87 & $\cdots$ & $\cdots$ & $\cdots$ & $\cdots$ \\
\hline Brewer's Blackbird.............. & $\cdots$ & 79 & 79 & 83 & 75 & 83 & $\cdots$ & $\cdots$ \\
\hline English Sparrow . . . . . . . . . . & \begin{tabular}{l|}
1 \\
2 \\
\end{tabular} & $\begin{array}{l}46 \\
36 \\
\end{array}$ & $\begin{array}{l}41 \\
40 \\
\end{array}$ & $\begin{array}{l}42 \\
40 \\
\end{array}$ & $\begin{array}{l}43 \\
38 \\
\end{array}$ & $\begin{array}{l}34 \\
14 \\
\end{array}$ & $\begin{array}{l}\cdots \\
\cdots \\
\cdots\end{array}$ & $\ldots$ \\
\hline Western Vesper Sparrow........ & $\cdots$ & 38 & 38 & 34 & 42 & $\cdots$ & $\cdots$ & $\cdots$ \\
\hline Black-headed Grosbeak.......... & $\cdots$ & 62 & 60 & 58 & $\cdots$ & $\cdots$ & $\cdots$ & $\cdots$ \\
\hline Latrk Bunting. . . . . . . . . . . . . & $\cdots$ & 56 & 56 & 56 & 521 & $\cdots$ & $\ldots$ & $\cdots$ \\
\hline
\end{tabular}

If, now, one examined these various egg weights some interesting conditions appear: First as to isolated cases of comparisons, one notices that the ostrich and kiwri have equal lengths of incubation, yet the ostrich egg weighs three and three-quarters pounds, while that of the kiwi is less than a pound; a pigeon's egg weighs five times more than an English sparrow's (in fact the pigeon's egg is heavier than the sparrow itself) but there is only three or four days' difference in the incubation periods of these two species; the eggs of the yellow-billed tropic bird and those of the guinea hen are almost identical in weight, nevertheless these two species have ineubation periods differing in length at least four days. If one make a curve of the incubation periods, arranging them according to the weights of the eggs, the heariest first. it can be noticed that a gain there is a general tendency for the incubation length to shorten as the egg is lighter, but there are so many sharp deviations from the expected regularity that one suspects that there is another factor, not influenced by the egg weight. which is at work in fixing the length of incubation or at least such a second factor is working in conjunction with the effect of egg weight. This possible second factor will be discussed in the later portions of this study. Suffice it here to say, that, while this list of $\mathrm{egg}$ weights is one altogether too short on which to base a final judgment, which must be held for the time in abeyance, these curves and such other considerations as just outlined compel me to believe that egg weights are 
only loosely related to the lengths of incubation, and both are eflects of another single underlying character.

The mole consideration. I have given to this phase of our problem, the more incredible it seems to me that conditions as variable and elastic as the size and weight of eggs have been proven to be, can have much, if any, influence on the true duration of incubation, an epoch in the individual's life of the utmost importance to it and its race.

\section{Age of the Egg}

Any effect that the age of an egg may have on its incubation duration is probably correlated with the length of viability of such ego. by which term the writer would have understood the possibility of the embryo's remaining alive without the $\mathrm{eg} g$ being incubated. Viability undoubtedly varies with the species, and too, it must be related to the number of egos in a set, and to the time interval between the laying of the eggs in such a set. It is self-evident that, often, with the ruffed grouse, the first egos must remain viable at least fourteen days. It appear's from Crandall's observations (9t) on an emu in captivity that this particular bird laid six eges at intervals of five days each; if this were to occur in nature and all the egos were to hatch it would show an amazingly tenacious viability for this species. Picknell (160) states that in captivity the ostrich lays twelve to sixteen eggs during a period of thirty days, and at the end of that time begins to incubate, which is another example of long viability.

I believe that egos of the lower birds will be found to remain viable a much longer period than those of the higher birds: I douht very much that a robin's or a humminglomes ego would remain viable, even with extraordinary care, three or four weeks after being laid. The grounds for this belief are that long viability is probably a reptilian character, and is related to a particular phase of a birl's physiologre to be discussed later on. It is highly desirable to have this question of the duration of viability of birds' eggs thoroughly investigated. All that I could find in literatme on this question was that hens' eggs remained viable up to the end of the eighth or ninth day, and those of pheasants, up to the fifteenth or twenty-first clay. Inside of the limits of viability, the age of an $\mathrm{egg}$ (at least a hen's $\mathrm{egg}$ ) unquestionably seems to influence the apparent length of incubation, for if fresh and old egos be placed together in an incubator (or under a hen. it is sairi) (16i2). the fresher eges hatch first. It also appears that the nearer the $\mathrm{egg}$ is to its limit of viability when placed under incubation conditions, the longer it takes to hatch.

Heinroth (162) says that some ducks sit upon their eggs at night during severe cold, to protect them until the 
full set is laid, and yet that all of the set hatch on or about the same time. This statement uncovers a possibility which is of interest, and it is also one needing further investigation; it is quite possible that the first egos laid in such a set undergo a slow but appreciable development, a speed of embryonic growth which is perhaps never quite equal to that of the later fresher eggs of the set, yet the amount of development in the first eggs make up for the lack of developmental speed and all the eggs in such a set mature at the same time. One must not forcet that there is an appreciable degree of derelopment of the embryo before an egg is laid, and that it is probable that the speed of this "uterine" development is continued at the same, or at an accelerated speed if the egg be incubated at once after being laid, and, contrariwise, if this initial derelopment be suspended for a considerable time after the egg is laid, the developmental process is slow in speeding up and in getting under way again, all of which apparently elongates the true incubation length. It is said (49) that perfectly fresh turkey eggs, if incubated at once, hatch a "few hours earlier" than older eggs. This whole question of the behavior of fresh and older eggs, especially of wild birds, under incubation conditions needs attentive and thorough investigation, especially through the channels of experimental methorls.

\section{Influence of the Shell}

How much difference, if any, variations in the egg shell make in the duration of incubation of birds' eggs under natural conditions is unknown to me, and it seems, a priori, that this question would be exceedingly difficult to settle. It is a well-recognized factor producing variations in the success of artificial incubation of hens' eggs, since all poultry raisers advise against mixing the eggs of different poultry breeds in the same incubator, alleging deciding want of success with such practice, and ascribing this to different degress of thickness, hardness, coarseness, porosity, etc., of the shell of diflerent breeds; this assumption probably has some truth, for these diflering conditions of the shell might affect the readiness with which such eggs respond to the heat of the incubator. It is probable that shells thinner than normal would permit of too rapid radiation when uncovered, which, if prolonged, would result in the embryonic growth being slowed down, only adding hours or days to the true length of incubation, and not causing a permanent modification of this specific length. The proof that the shell of eggs of wild birds varies is too clear to be overlooked, and its possible modifying effect on the length of incubation cannot be disregarded. However, Meyer (178) has shown that the egg shell of the song sparrow can vary $46 \%$ in the weights of 
the extremes of different eggs: there is no evidence of any similar variation in the incubation period of this species.

Further study on this point is to be made before one can render a verdict for or against it.

\section{Size of Yolle}

It has been suggested by Pycraft (138) that an abbreviation of the incubation period with many birds has been brought about by a gradual lessening of the "food yolk," presumably meaning that part of the egg commonly termed the yolk.

Enunciated by so keen a student and investigator, and such an original thinker, this suggestion must be considered with care and attention.

It is extremely difficult to discuss this idea in any way, both becanse P'ycraft produces no statistical or experimental evidence in support of his theory, and because there seems to be no information available concerning the size of the yolk in various birds' eggs.

The only publication coming to the writer's hands, which throws any light on this theory is a paper by Curtis (140), dealing with the factors which influence the size, shape, and physical constituents of the egg of the common hen. In this study (a model of its kind) the yolk is shown to be the second most variable component of the egg, and that of two eggs, the yolk is relatively larger in the smaller egr; also that the weight of the yolk is not determined, for example, by the hen's weight alone but that it is markedly modified by her hereditary constitution, physical condition (state of health), stage of development (age), the season of the year. and the position of the ego in the series of egoss laid at the time. If these decluctions by Curtis apply equally well to other birds' eggs, and, until shown otherwise, it is fair to hold that they do, it is difficult to see how Pycraft's suggestion can be tenable. since, in general, the shorter incubation periods are characteristic of birds laying small eggs, which, as has just been shown, have relatively larger yolks, in place of smaller yolks. as his hypothesis requires.

Pycraft mentions specifically, as having reduced yolksize (or weight?) "razorbills, guillemots, (and) many gulls," but it is not possible to resolve this problem as it may apply to these and other species, until the relative sizes of their egg yolks be determined and the periods of incubation of these species be compared and viewed as to their relation to such yolk sizes. While judgment must be suspended also on this point, at least until a considerable mass of information relating to the size of the yolk in the eggs of different species of birds be secured, still it seems to me that this hypothesis is rather dubious. 


\section{Telluric Influences}

Under this caption are to be included the supposed effects of :
A. Geographical zone
B. Climate
C. Weather
D. Geographical residence of species
E. Site of nest.

All of these have been mentioned by various writers as being conditions controlling or determining the incubation length; I am convinced that such influence any of these may have on the length of incubation is merely that of cooling the eges and retarding the embryonic development, merely adding hours or dars to the trie length of incubation, which apparent length returns to the original if the retarding influence be removed.

It has been abundantly demonstrated with eggs in artificial incubation. that the duration of incubation can be extended by subjecting the eggs to temperature lower than the optimum, and that the degree and duration of the lowering of the temperature have limits, beyond which the embryo dies. Tet it is astonishing how much cooling or chilling a set of eggs will successfully withstand in incubation.

The writer has known of a set of house finches' eggs being left uncovered all night during a spell of cold weather, and ret producing a full number of normal and vigorous nestlings. The structure of the ego lends itself to resistance to too rapid cooling, for the shell, with its small "pores" full of air, and the shell membrane, together, make a goorl insulating medium. Brehm (quoted by Ingersoll, 110), says it refuires one hour and forty-five minites at fifteen regrees, Fahrenheit, to freeze a living egg; this means that it takes seventeen degrees, Fahrenheit, of frost for nearly two hours' exposure, to kill the developing embryo, and it is apparent that this time may vary proportionately with the size of the egg. It is well known that eggs in the later stages of incubation cannot resist successfully such low, or prolonged low, temperature as just mentioned, but that they do successfully withstand milder degrees of frost for much longer periods, especially during the early days of incubation, is equally well known.

It is also known that the incubation period of the domestic hen can be prolonged to the twenty-third or twentyfourth day by judicious cooling during incubation. That this effect of cooling obtains during the incubation of various other birds at large is undisputed.

\section{Zone}

The writer has been unable to find any published information bearing on the possible effect of geographical zone on 
the length of the incubation period, though one or two general statements have been encountered, given, however, without any detailed facts in support of the same. Newton (2.5) says that there have been "no observations made on the question if there be a difference in the length of incubation between polar and tropical individuals of the same species." Arrigoni (12) is the only writer whose statement on this point is definite, though it is unacompanied by substantiating facts: he says "it seems, however, that birds of the same species which nest near the pole, and near the tropics, have equal periods of incubation" (sembra pero che gli nidificono e presso al polo e presso i tropici abbiano ecpuale periodo de incubazione). It is highly probable that the bodily temperatures of birds (as is the case with Homo) vary little, if at all, with changes of zone, being, most likely, the same at the polar region as at the tropics; there is, however, some evidence which points to the posibility that atmospherie conditions may influence a bird's temperature, but the question has not yet been thoroughly studied and worked out. Nevertheless. I helieve that hinds. while incobating. womld be able to maintain the necessary optimum incubating temperature equally well in the cold zones as in the hot zones. In this connection, one must not forget that a large number of birds' nests are constructed of such material and in such a manner. as to retain to the best adrantage the heat applied by the parents to the eggs, facts which bear especially on the question of incubation at the polar regions, the eiders being marked examples of birds with nests built to retain heat. The huge, bulky magpie nest has a central bowl of nonconducting clay or mud, and in many nests are incorporated most excellent non-conductors of regetable or animal matter. The chipping sparrow uses horse-hair, the writer has found a nest of the Arkansas kingbird lined with rabbit's hair and a house finch's nest lined with sheep-wool; and what better non-conductor can be found than the cotton-like mass of the hummingbird's nest?

Far be it from the writer wishing to be understood as holding that these materials are consciously selected for the purpose by the nest-builders; attention is merely called to the fact that provision to retain the applied heat is to be found in many differing nests, and the nests of the polar regions are no exceptions.

Many birds successfully go through the duties of incubation during the winter, when the forests are deep with snow, and akin to the aretic regions, yet. so far as I know, this does not seem to change their incubation period in comparison with their relatives nesting under less rigorous conditions. If the foregoing be true, it seems to me that geographical zone has no effect on the true length of incuba- 
tion. It is stated by Chapman (65) that individuals of the same species living in the Tropics lay fewer eggs than do those in Northern regions, and it would be of value and help if one knew if this difference in the number of eggs is accompanied by a change in the incubation length, all of which still remains to be investigated. At the same time, it is necessary to call attention to the fact that the snow bunting's length of incubation is much out of relation to the periods of other fringilline birds, a fact possibly due to zone, or to errors of observation, and that Clarl's crow has an incubation period which is rather long in comparison with others of its family, or its taxonomic position. One of its congeners (the Canada jay) nests during the snows of winter, and at high altitudes, too, without having an unusual length of incubation.

Some records of incubation lengths state that the eider ducks (137) have a shorter period than does the domesticated duck in warmer climate. Such statements remain to be substantiated, but still add force to the belief that, in the future, incubation lengths must be studied with an eye to eliminating such influences as slow down and prolong embryonic derelopment. and thereby distort the true incubation period.

Heinroth (162) believes that the short periods of Mereca penelope, Chen rossi and Dafila acuta (which he gives as twenty-two to twienty-three days) is due to the short northern summer; granting that these periods are correct, why is the period of the teal in more southern latitudes no longer? Is the period of the Emperor penguin nearly fifty day's, because it occur's in the dark, winter months? I think not.

\section{Climate}

Information on the possible effect of climate on the incubation length is absolutely lacking, so far as the writer has been able to determine. It is conceivable that a species living in a moist climate might be unsuccessful in incubation, if suddenly made to live in an arid region (or vice versa), because of its egg's structure having been adjusted for generations to a given arerage humidity, which adjustment fails in the new locality. While such a possibility is extremely remote under natural conditions, a similar result does occur with hens' eggs in artificial incubators in Colorado (a semi-arid region), the writer having been given to understand that failures to hatch in incubators. in Colorado, are frequently due to egg dessication. It would shed some light on this question if one knew if there were any difference in the lengths of incubation of white heron in India and in Europe, because of the two-fold effect of differing egg size, and climate. 
Climate alters the size, color, shape and many other characteristics of birds, but does it change the incubation length? This remains to be demonstrated. If it does, it is probably exceedingly slow in effect, and only through minute increments slowly accumulated, and probably always. producing alterations on the side of a shorter true length of the incubation period.

\section{Weather}

It is said that varying weather conditions change the incubation period, and while the writer has found in his study of the house finch (77) that, short of actual freezing or prolonged chilling. the weather has no inthence whatsoever on this species' incubation period, and Macdonald's (146) report on the incubation of the horned lark seems to point the same way, yet Job (95) states definitely that the inculation perion of the qualil is one day longer if the weather be very cool or wet. and Kinight (10.) states that he has recognized a prolongation of two to four days in the incubation periods of eertain species of Lanius and of Geothlypis because of varying weather conditions. It is possible that prolonged dronghts might also prolong, or, in fact, renrler monsucesesful natural incubation beeause of a tendeney to $\mathrm{eg} g$ dessication or to over-heating if the parent were compelled to leave a nest uncovered too long. I believe that if there be any difference in the length of incubation seemingly referable to weather, that future careful study of such effects will show that the true length is not altered, but that the change is merely one of prolongation due to cooling.

\section{Locality}

Geographical locality has been mentioned as a cause of differing lengths of incubation in similar, and in unrelated, species. I know of no indubitable support for this theory. There is no evidence that a robin's period is longer or shorter in New York than in Georgia, or Colorado, or Canada; on the contrary, all the facts seem to support the opposite idea that there is no change in the period, whatever the locality.

\section{Site of Nest}

Casey Wood (104) says that the English sparrory's incubation period "varies slightly between twelve and thirteen days, depending on the weather. the 7ocatity of the nest*, and the anment of time the lired is on the nest." a variation, so far as the nest site is concerned, patently due to the varying temperatures produced by a well-sheltered or an exposed nest. the sheltered nest pronoting optimmm conditions and a resulting true length of incubation.

Howerer, one writer (16i2) states definitely that site of

${ }^{*}$ Italics by W. H. B. 
nest produces, not variability of the incubation period, but differing lengths in different species. Thus, by this explanation. the tree-nesting ducks and the European vulture (Vulture monachus) have long incubation periods because of their nesting places being so located as to have security from ordinary foes.

This, however, does not explain the long incubation periods of ground-nesting Anatidae, such as a goose or a swan. nor can it be reconciled with the short incubation period of a flicker, with which species the nesting place is reasonably free from intrusion by foes, or the short periods of cliff-nesting swallows.

The writer believes that all of these supposed influences on the true length of incubation discussed above really bring about only a retardation or a suspension of embryonic development, a suspended animation in ovo, as it were, and that in no way do ther affect the true length of the incubation period, which, when distorted, is resumed with the next incubation or the following generation, granting the environmental conditions be normal. From the point of view of this study, one must carefully differentiate between a change of incubation length which is temporary and affecting only one set of eggs, and one which is peimanent, and passed on to succeeding generations.

Assuming, as one must, that chilling the eggs during incubation does produce such effects. the question must he interjecterl. "Do the eges of all hirds withstand equally mell similar degrees of chilling?" It must be considered because. if they do not, those birds whose eggs endure successfully the longer periods and greater degrees of cooling will exhibit a sreater variability in their incubation periods, the same being a sonere of perplexity in sturlying the problem in hand.

As has been intimated before. I believe that it will be found by future investigations (if it has not already been so determined) that egos of the mole primitive birds will remain viable under adverse conditions much longer than will those of the higher hirds under like conditions; in other words, under like conditions of cooling, rough usage and neglect. a duck:s ego will be viable long a fiter a lobin "s egor will he spoiled. I doubt if thrushes', wathlew'. finches' and swallows egers would hatch if suljjected to a conres of treatment as was given to some egos of "shore birds" by Beebe (114). This observer gathered a number of egos of terns, skimmers, gulls, green herons (all the eggs being well on in the incubation stage) for purposes of embryologic study, which were carried about for sereral days without any suspicion of their remaining viable; yet several hatched on being placed in an incubator, and produced normal "chicks," 
which grew to maturity. This experience discloses but one more of the many interesting points embraced in this problem, which are yet to be thoroughly studied and settled.

\section{New Explanations}

Body-weight: egg-white index, and incubation length.

Newton (25) says that "the size of the egg is generally, but not at all constantly, in proportion to that of the parent," attributing this relation to the necessity of the parent being able to completely cover and incubate all the eggs it lays in a set. This relation between the size of the body and of the egg is only general. It is also true, in a loose way, that the smaller is the bird, the smaller is its egg. There are many notable exceptions to be found on either side of the equation; the kiwi (168), megapods (16), some gallinaceous birds, and the barbary duck (161) lay eggs very large in proportion to their bodies, while with storks, cuckoos and several other species the reverse holds true.

These facts, and my own study of the weights of birds and their eggs, suggested to me that there might be some relation between the ratio of these two weights and the length of incubation of the egg. This possibility was investigated far enough to demonstrate that there is not the least relation discernible between the two, hence it is mentioned here, only to be dismissed.

\section{A New Explanation Based on Physiologic Grounds}

Most of the explanations previously propounded seem inadequate, and more or less illogical, because they have been based on passive conditions, such as an anatomical character ( of eger). or have been built on efiects which merely retard or suspend embryonic development, effects which do not alter the true or specific length of incubation. None has been directly correlated with an active biologic or a physiologic process or condition, which alone, it seems to me, can directly modify so vital a span as is the true duration of incubation.

Only two of these past theories have been founded on physiologic grounds-longevity and the health of the parents. The first cannot at present be said to have any bearing at all on the duration of incubation, and the second is inseparably related to another which seems to have an allimportant influence on the true length of incubation, a condition now to be taken up and discussed.

It is hard to realize that a fertilized $e g g$ is, during incubation. not an organ or a detached part of a precerling bird, but that it is in reality a growing new individual, and as such must respond, or be subject, to control by special 
biologic and envirommental conditions, which probably are peculiar for each family, or perhaps for each species.

This is not an idle fancy, for it has been shown by experimental investigations (156) on the temperature of developing bird embryos that "the embryo of a chick must be looked upon as a cold-blooded animal" during the early days of incubation, and that later it shows more and more characters of a warm-blooded animal. If this contention be correct, then the fertilized egg, as such a new individual, must be, in its growth, fitted, and respond, to conditions peculiar to it and its immediate ancestors. In other words, it must be in consonance with its environment, and react to, and be affected by, it as in any other individual. The physiology of the embryo is determined both by its heredity and its environment. Wrould it not be logical to look for the factor or factors. condition or conditions, which fix the true length of incubation amongst the environmental conditions which make for or against the health of the developing new bird? Would it not be wiser to seek for an answer to our problem in the domain of the bird's physiology?

It has already been stated that, for an egg to be successfully incubated, it must be subject, during incubation (a) to a correct position. (b) to an atmo-iphere of proprer moisture content, and (c) to a certain degree of temperature.

The attainment of a correct position for the egg during incubation is apparently automatically brought about by the movements of the incubating parent with all birds except the megapods. It seems undecided whether these singular birds do or do not visit or disturb an egg after it is laid.

The proper amount of moisture necessary for the preservation of the embryo is probably attained by selection, through a long process of adaptation to the surrounding prevailing humidity: it would be valuable to lnow if egos of individuals of the same species. incubating in humid and in arid regions, exhibit different egg shell structure in order to compensate for humiclity differences in such antipodal regions. It is possible that in natural incubation the moisture emanating from the incubating parent's body, or from the soil under a ground-nesting species, also may be a factor, and help combat undue dessication during incubation. It is said that the Egyptian plover (Pluvianus regptius), whose eggs are partly incubated by the direct heat of the sum, dampens its eger by contact with its previously watersoaked feathers.

The first of these two requisites seems to be one of pure physics only, and the second one largely of physics, with perhaps an added element of physiology.

How important is the first in natural incubation I am 
mable to state; nevertheless, it seems important in artificial conditions, since most poultry raisers insist that with hens' eggs in artificial incubation it is very essential. The second is obviously a sine qua non, yet being largely one of physics, it does not seem in reality to affect the length of incubation, but rather the life or death of the embryo. Hence, since neither of the first two essentials for successful incubation is one of a bird's physiology, it remains to take up the last, and since the heat applied to eggs in natural incubation emanates from the setting bird, it would appear that the factor of the degree of temperature applied to the eggs is one of pure physiology, a question of the production and application of animal heat. Moreover, it can be said, without fear of contradiction, that temperature is the most important of all the three factors (or conditions) just enumerated. Now, inasmuch as the incubation heat comes from the brooding parent (true or foster), excepting with the megapods and (possibly for a part of daylight hours) with ostriches and the Egyptian plover, it woild appear that the bodily temperature of the incubation parent should be a highly important factor in relation to the incubation period. In brief, it seems to me that birds' temperatures should be investigated, not only as such, but also as to any relation they may bear to the incubation period, and also any other facts cognate with birds' temperatures.

If a bird's temperature be highly necessary to successful incubation, it would seem reasonable to predict that birds have acquired habits, and conditions of body exhibited only during incubation, which are calculated to facilitate the application of, and conserve, the heat applied to the eggs during this period.

A superficial consideration of birds' nests throws some light on this question. While a goodly number of nests are too flimsy, or in too close contact, apparently, with the earth to aid in concentrating the heat applied to the eggs, nevertheless a majority of nests are so constructed as to retain this heat most advantageously. It is obvious, however, that nests may have been dereloped. and probably did arise, as a protection to, and receptacle for, the eggs, yet the almost innumerable instances where the nest materials are ideal as insulating media show that out of this primary use of a nest has grown the concomitant result of the conservation of the all-important heat applied during incubation.

Reciprocally there are conditions normal to the bird, or found only during the incubation time, which lend themselves to the application of a maximum amount of the parent's heat to its $\mathrm{egg}$, and to holding this heat at the most advantageons level. Tucas (10) has maintained that the majority of hirls have no feathers on the abolominal area 
in order to more successfully incubate their eggs, saying "the bare spaces of the body of a bird are adaptive * ** $*$ (the) belly (is) bare in most birds because of incubation, and in ducks, penguins and auks becomes bare during incubation." Pycraft draws attention to a further step in this process, and says that the bare abdominal area becomes secmingly inflamed, with its blood ressels more distinct than normal, a condition not likely to be a true inflammation, but a functional hyperemia only, resulting in a more plentiful and more frequently renewed blood supply to the parts, in the end maintaining more easily the optimum incubation temperature.

Before entering upon a larger consideration of bird temperatures and their relation to the length of incubation. it seems desirable to consider briefly a few facts concerning the effects of heat applied to viable eggs.

There is a small amount of development in a fertile egg before it leares the body of the parent. but it is very slight, and never reaches any advanced stage as is the case with many near relatives of birds, the reptiles, with which animals incubation of the ego frequently goes on to completion within the body of the female. and the roung are born alive. resulting in the fact that while many reptiles are ovoviparous, birds are never anything but oviparous. The slight development in an egg which starts and goes on while it is still within the female's body continues for a while at a very slow rate after the egg is extruded, even under comparatively low temperatures, viz., $86^{\circ}$ F. (38). Prolonged or excessive chilling or over-heating promptly kills the embryo. And both of these effects are persistently avoided by incubating parents; thus ducks, ete., cover their eggs with down or feathers when leaving the nest in cold weather, and the ostrich shades its egos with its borly and wings from the sun's excessive heat (160).

It is demonstrated that there is an optimum incubation temperature, and it is almost demonstrated that each species of domesticated bird has an optimum of its own, an optimum which hatches the eggs in the shortest time possible, and which probably varies little, if at all, with each species.

Nevertheless, it is extraordinary how, for example, a hen's egg will hatch under what seem anything but optimum conditions; thus, such eggs have been known to hatch in a barn-yard manure pile (33).

H. Milne-Edwards gives the optimum (without designating for what species) as $10 t^{\circ} \mathrm{F}$. Various other figures have been given for this incubation optimum, a conflict arising, most likely, becanse the optinnm difters with differing species. 
There is support to the further idea that the optimum may vary according to the stage of the incubation. Job (95) saly that for ducks (sp!) the best temperature during most of the incolustion is $10: 3^{\circ}$ F.. and slightly before or at hatching it is $101^{\circ}$ ir. (One might predict this. It is a faret that with many birds, as the incubation period nears its close, the bird's belly becomes more and more bare, permitting a closer and closer contact of parent to eges, a condition facilitating heating of the eggs; and, too, that towards the close of inculation the eages themselres. especially in a large set of exger. produce and disseminate heat $(16(\theta))$ : these two facts forming a combination calculated to sulject the egas to a gradually rising temperature as the incubation nears completion.

Furthermore, on the basis of what is known about avian (embryonic and post-embryonic) temperatures, this gradual rise of the incubation temperature would square with what goes on within the egg as it is incubating. I am not doing vichence to the farcts. nor ret making an orerelraft on the imagination, in believing that a new bird, in its embryonic development, climbs up a series of evolutionary levels, from low to high, and that under these circumstances one would expect to find lower temperatures more fitting to the early parts of the incubation period, and higher temperatures in the later portions of the period, differences which may be slight, yet none the less significant. The optimum incubating temperature (in artificial incubation) for the domestic hen is given as $102^{\circ} \mathrm{F}$. (early) and $103^{\circ} \mathrm{F}$. (late) (33); for ducks (-p)!) for the first three weeks as $102^{\circ}$ F.. and the last week $103^{\circ} \mathrm{F} .(34)$; for the ostrich $101^{\circ} \mathrm{F}(160)$, and for the rhea (Rhea Americana) as $103^{\circ}$ F. (13).

There is a large field for research in this question of temperatures of artificial incubation; there is also an engaging and unexploited field for investigation in the temperature conditions of the nest in natural incubation; special thermometers have been constructed to register this temperature, but the data are too few to require special notice here. This method of study might be undertaken with the aid of the ordinary clinical thermometer, and it remains to, and should, be vigorously prosecuted.

While it is known that there is a slight upward swing of the optimm temperature towards the cond of artificial incubation. it has not yet been clemonstrated in natural conditions. Still so much points to the high probability of its existence also in natural incubation that one can safely accept it as tentatively demonstrated.

If there be an optimum incubation temperature, which varies with the species and, also, according to the degree of embryonic development in the egg, it would seem safe 
to predict that differing bird species should exhibit. under normal conditions of health, differing body temperatures, and perhaps, in a given individual, this normal temperature should be found to vary according to the stage of incubation. since the parent's body heat is that which derelops its embryo in practically all of the myriads hatched each year.

It then becomes self-evident that the optimum incubation temperature for any species is the temperature of the incubating parent (true or foster).

The physiology of a bird's temperature is not nearly so well known as that of man and other warm-blooded animals, but there is, nevertheless, enough information on the subject to enable one to get a fairly comprehensive riew of its physiologic characteristics.

Birds are homoiothermic; they have in health a body temperature which is relatively characteristic and of a constant curve, one peculiar to the family, the genus, or possibly even to the species. This temperature, with all species so far studied. has a daily swing, being highest. with diurnal birds. between noon and six in the evening. and lowest between midnight and six in the morning, these extremes being reversed with nocturnal birds (167). The amplitude of this daily temperature swing varies with different species, and seems to be correlated more or less closely with the bird's size. since Fimposon (16it) found it to be widest with small birds and narrowest in large birds, there being 7.68 $\mathrm{F}$. between the extremes with a thrush, and 1.6.5 F. for a duck. and with birds of intermediate size this swing was intermediate in amplitude. This daily swing of body temperature corresponds fairly closely with the bird's activity, being lowest when it is at rest, $i . e$, the hen's temperature is lower mhile inculating than when active: it remains nearly constant during most of the period of incubation, and rises only when the hen becomes more active and "excited" at the hatching of the eggs. It is said (164), however, that the temperature of the nest is lowest in the first week of incubation and highest at the end, a change possibly not due to the hen's temperature alone, but also to the egos themselves producing heat as the embryos derelop. This twenty-four hour rise and fall of temperature also obtains with man, and is also slightly correlated with his condition of activity or rest; the curve can be reversed if his daily mode of life be reversed, a fact throwing light on the reversed curve in nocturnal birds. There is some evidence at hand showing that the female carries a higher temperature than the male (165-167), since with cormorants, guillemots, razorbills and ducks the females have the higher temperature, the excess varying between $.07^{\circ} \mathrm{F}$. and $.5^{\circ} \mathrm{F}$. This difference may seem negligible, but it must be noted and borne in mind 
when investigating this subject. It has been determined that a hen's temperature varies stightly with the season, highest in the summer, and nearly, or exactly, identical in May and October. I am inclined to believe that there is a tendency to an increase of temperature during the mating season, since I have found the cock ring-neck pheasant's temperature much higher than the female's at this time of the birl's physiological rear, and Pickrill (1!1) sars that there is an increase of about $2^{\circ} \mathrm{F}$. at such times with both sexes of the ostrich. Ingestion of food and muscular activity elevates (slightly) the temperature in man (156) and seems to do so also in birds. The support to this latter statement is indirect only. A setting hen's temperature (166) is lower than that of an active "oont pol " hem, and the "control's" temperature is lower at night, as shown if taken when the bird is gently lifted at night from the perch. An under-fed or a starved hen (165) has a lower temperature than the normal control bird; this diflerence borders closely, however, on the domain of pathology, into which it is inexpedient here to enter.

Birds have bodily temperatures which are only slightly affected (156) by climate. Individuals of the same species in the Aretic region have the same temperature as those in temperate zones, showing the wonderful control of body temperature by the heat centre of the central nervous system, and nothing shows more vividly the power of this control than the experimental demonstration that a sparrow, with its feathers all clipped off, maintains its body heat. under ordinary temperatures, quite easily at normal.

The age of a bird has no relation to its body temper'ature, except that altrical birds do not acquire a stable and normal temperature curve until ready to leare the nest, or at least until muscular co-ordination is nearly or quite perfected. Precocious birds seem to have a perfectly functionating temperature controlling centre at hatching, while concerning the age and temperature, it may also be said that ducks varying in age from four to twenty-four months exhibited temperatures identical with those of older birds (165). The rectal temperature of a hen, taken immediately after it has laid an egg, is said to be $2^{\circ} \mathrm{F}$. higher than normal (164). I am unable to say that all these peculiarities of a hen's temperature apply also to all other birds, but until shown otherwise, it is necessary to hold that they do. The normal temperature of man is assumed to be the average of the highest reading of the twenty-four homr, ntilizing as large a series of observations as possible, and all of normal adults. Comparative physiology demands the same standard in other homoiothermic animals, having, of course, due regard for individual peculiarities (i. e., nocturnal animals 
and birds). Therefore, in this discussion, a bird's normal temperature will be taken to mean, not the mean of the records of twenty-four hours, but the highest in that period, or the average of such highest records; hence, the most desirable bird temperature records are those taken betwreen noon and six in the evening, accompanied by notes as to the bird's sex, age, method of securing the bird, and of other modifying factors, some of which have just been outlined.

The way of securing a bird to take its temperature varies, and it may have considerable influence on the result. Sea birds were caught with a baited hook and line for such purposese nearly a century ago (16.5). I have found, using trapped English sparrows. that the rectal temperature of these birds is the same before and directly after being shot, and Simpson (165), in studying other species, antedated me in this conclusion more than thirteen years. This conclusion is also true of flickers, since a male's temperature, directly after being shot, was $106.6^{\circ} \mathrm{F}$., while that of a female, taken alive (and afterwards liberated), was $106.4^{\circ} \mathrm{F}$.

This method of securing animal temperatures is approximately accurate, and is substantiated by similar methods with mammals (156); in all cases, care must be taken to note if the specimen bleed profusely (becomes exsanguinated), in which case there would be a swift descent of the temperature, or if the brain be extensively damaged, in which event it is possible that the temperature might be, for a short time, abnormally high. Whatever the method of securing a bird, a standiad self-registering clinical thermometer should be used, inserting it into the bowel a half-inch or more, according to the bird's size, and held in place untit the mercury ceases to rise.

It seems self-evident that the ideal time to secure bird temperature records would be while a bird is incubating, but this, at present, would be difficult to do to any extent large enough to be useful, and the next best time to take birds' temperatures would be while they they were breeding or in the brooding period. For the purposes of this study, any and all recorded bird temperatures must be utilized, even if all have been taken with little or no regard to their bearing on the length of incubation or to their relation to the peculiarities of the daily temperature curve. The number of published temperature records of birds is not large; aside from some records scattered through the literature of human and comparative physiology, and a few determined by myself, there are tro principal sources of information on this subject, the first being fomed in a list given loy II. MilneErlwards (:35). in 186i3, and the second, a brief hut highly suggestive study published by Sutherland in 1899 (112). 
Table No. 6 gives all the above mentioned records, plus a few scattered in other publications, some given to me by obliging friends, and a few determined by myself.

TABLE NO. 6

\section{Bird Temperatures in Deqrees Fahrenheit}

Weight Authority

Ostrich, laying season $9 \ldots \ldots \ldots \ldots \ldots \ldots 10.0 \ldots$

Ostrich, non-laying ................ 100.0141

Ostrich, breeding o ................ 104.0 141

Ostrich, average of five individuals....... $99.2 \quad 156$

Ostrich, highest of five individuals........ $100.0 \quad 156$

Emu ... . . . . . . . . . . . . . . . . . . . . 102.2112

Emu ...........................avg. $103.1 \quad 165$

Cassowary ...................... 102.56 112

Tinamou (Spotted) ...................avg. 104.06 112

Tinamou (Rufous) .................. 105.44 112

Apteryx (Mantell's) ................ 99.32 112

Apteryx (Haast's) o ................ $100.22 \quad 112$

Penguin (Eudyptula minor undina), Alive

...................................... 6, 101.3153

Penguin (Species?) .................... $102.2 \quad 10$

Penguin (Adelie) .................. 102.5 10

Horned Grebe (Colymbus auritus) ....... $105.26 \quad 165$

Albatross (Sp?) (Taken in 1836 and 1837)

................................. 103.82165

Albatross (Sp?) .................... 104.09 38

Diomedia (exulans or chlorhynchos?)

....................mean of nine $105.27 \quad 165$

Grand Albatross (taken in 1836 and 1837)

.........................mean $102.92 \quad 165$

Petit Albatross (taken in 1836 and 1837)

............................mean $106.16 \quad 165$

Pétrel $(\mathrm{Sp}$ ?) ......................... 103.1

Grand Pétrel Noir (taken in 1836 and 1837)

.........................mean $103.46 \quad 165$

Procellaria gracilis ................ $101.66 \quad 165$

Procellaria capensis ............... 103.5 165

Mutton Bird (Neonectris tenuirostris brevicaudis), alive................avg. 7 juv.-100.2 153

Procellaria pelagica (Storm Petrel)....... 103.64 165

Pétrel gris (taken in 1836 and 1837) .... mean $103.28 \quad 165$

Pétrel damier (taken in 1836 and 1837) mean $105.26 \quad 165$

Cormoran $(\mathrm{Sp}$ ? ) ................ $106.16 \quad 38$

Phalacrocorax carbo (Cormorant).....mean 103.5 165

Phalacrocorax graculus (Shag) ....... mean 106.4165

Sula bassana (Gannet) .............. mean $106.6 \quad 165$

Black-Crown Night Heron ô May 2, directly

after being shot................. $102.3 \quad 182$ 
Weight Authority

Heron $(\mathrm{Sp}$ ?) .................... $105.8 \quad 156$

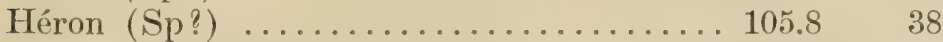

Merganser $(\mathrm{Sp}$ ?) ...............mean $106.75 \quad 165$

Duck (Sp?) (24 individuals) ...........avg. $107.8 \quad 156$

Mallard Duck (tame, three removes from wild) 0 . . . . . . . . . . . . . . . mean $106.7 \quad 165$

Mallard Duck (tame, three removes from wild ) $9 \ldots \ldots \ldots \ldots \ldots \ldots \ldots \ldots$. . . . . . . . . $106.88 \quad 165$

Domestic Duck ô...........avg. maximum 107.24 167

Domestic Duck o. . . . . . . . avg. maximum 109.4 167

Domestic Duck o ............avg. of fifty 107.5 165

Domestic Duck q ............. avg. of sixty 108.0 165

Canard commune ................... 109.58 38

Duck (Sp?) ...................... 105.08 10

Anas rubripes (Black Duck) .......... mean 106.34165

Aix sponsa (Wood Duck) .................. 107.6 165

Canard Millouin (Pochard?) . . . . . . . . . 108.68 38

Marila aftinis .................mean $106.2 \quad 165$

Eider Duck ....................... $108.32 \quad 38$

Oedemia nigra .................mean $106.34 \quad 165$

Clangula clangula americana........... $104.72 \quad 165$

Goose (Sp?) ..........five individuals avg. 107.0 156

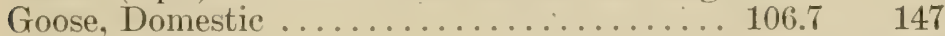

Oie commune .................... 106.7 38

Oie rieuse (Cackling Goose?) . . . . . . . . $109.4 \quad 38$

Cygne à bec rouge................. 105.78 38

Prairie Falcon of in December, immediately after being shot. . . . . . . . . . . . . 106.6 78

Fancon ........................ 104.9 38

Hawk (Kestrel?) .............avg. max. 108.32 167

Hawk (European Sparrow ?) . . . . . avg. max. 107.3 167

Tiercelet ..................... 106.52 38

Autour ......................... 109.58 38

Western Red-tail Hawk, in August, alive. .. 106.278

Swainson's Hawk o alive, April 24...... 106.6 78

American Rough-leg Hawk ô in December, after being shot.................. $105.8 \quad 78$

Osfraie ....................... 104.36 38

Gypaete .................... $105.8 \quad 38$

Globose Curassow 우 alive, in captivity .avg. 4-106.4 169

Globose Curassow ô alive, in captivity .avg. 3-106.4 169

Gellinotte $(\mathrm{Sp} ?)$........................... 38

Lagopede (Sp?) ..................... $106.88 \quad 38$

Natal Francolin (Francolin natalensis), in captivity, $3: 30$ p. m................ $107.9 \quad 97$

Willow Grouse of (taken in Aretic regions). $109.04 \quad 156$

Prairie Fowl o ................... 109.4 156

Prairie Fowl ${ }^{4}$................. 109.76 156 
Weight Authority

Turkey . . . . . . . . . . . . . . . . . 109.0 156

Dindon ....................... 108.86 38

Guinen Fowl .................... 110.0 156

Pintade .......................... 111.02 38

Pheasant $(\mathrm{Sp}$ ?) .................... $108.7 \quad 156$

Ring-neck Pheasant ô........avg. of two 107.5 109

Ring-neck Pheasant o . . . . . . . . . . . . . 106.0 108

Domestic Fowl \&..............avg. max. 107.3 167

Domestic Fowl. . . . . avg. of 111 individuals $106.9 \quad 156$

Domestic Fowl o. . . . . . . . . . . . . . . . . 107.6 147

Domestic Fowl o. ................... 106g. 1065 38

Domestic Fowl of at large..... avg. of three 10t.6 109

Domestic Fowl, laying, and at large....... 106.3 164

Domestic Fowl (Leghorn), laying hens.avg. 3107.7153

Domestic Fowl (Leghorn), laying hens, after exercise ................... 108.4 153

Domestic Fowl, lifted from perch at night... 105.08112

Domestic Fowl of setting. . . . . . avg. of two $103.6 \quad 109$

Domestic Fowl, "setting, average of many". . 105.6108

Domestic Fowl, brooding by day.......... 107.06 112

Domestic Fowl, setting.............. 106.7 164

Domestic Fowl ô............... avg. max. 107.5 167

Coq .............................. $103.46 \quad 38$

Bantam o................... max. 107.8 167

Bantam, Leghorn, setting............. 104.0 109

Bantam ô..................avg. max. 107.39 167

Paon ........................... 107.15 38

Fonlque ...................... 104.9 38

Sun Bittern (Europygia helias) in captiv-

ity, $3: 30$ P. M....................... $102.4 \quad 97$

Pluvier ..................... 104.9 38

Hooded Dotterel_-"One minute dead"...... 107.0153

Killdeer o June, taken immediately after being shot ...................... 106.6 78

Barge ...................... 107.98 38

Chiornis minor (Sheathbill), taken in 1836

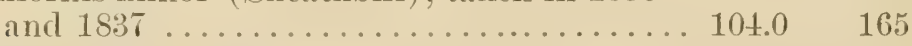

Stercoraire Pomer....... . . ........ 104.54 38

Le Cordonnier (Megalestris skua?) . . . mean $104.2 \quad 165$

Rissa tridactyla ................mean $106.6 \quad 165$

Monette tridactyla . . . . . . . . . . . . . . . 105.26 38

Monette blanche ..................... 104.18 38

Larus argentatus. . . . . . . . . . . . . $108.32 \quad 165$

Goëland argenté.................... 108.14 38

Larus canus.................mean $107.1 \quad 165$

Common Sea-gull, juv............avg. max. 106.7 167

Larus fuscus.................mean $106.9 \quad 165$

. Goëland à manteau gris............... 105.26 38 
Weight Authority

Moutte gris..................... 106.52 38

Gull (Sp?) ...................... 100.4 139

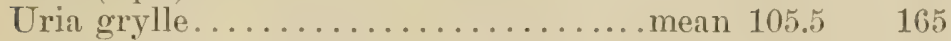

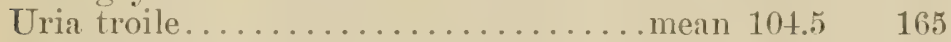

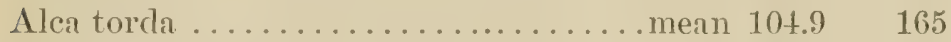

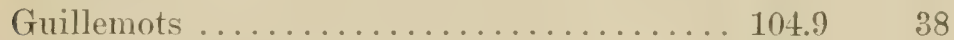

Pigeon, Domestic.................... avg. $107.87 \quad 38$

Pigeon, Domestic.................... 107.6 147

Pigeon. Inmestic . . . . . . . . . . . . . . . 108.0 156

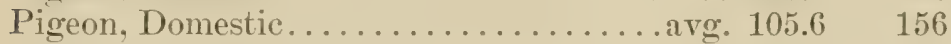

Pigeon, Domestic.................. 107.24 156

Pigeon, Domestic o................ 107.45167

Pigeon, Domestic 아 brooding, noon....... 104.0 78

Pigeon, Domestic ô.............avg. max. 106.75 167

Speckled Pigeon (Columbia phæonota), in

captivitr. $3: 30$ P.M.............. 110.+ 97

Mourning Dove, in captivity, with crippled

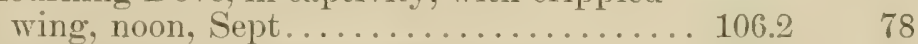

Rudely Quail (Geotrygon Montana) ....... 110.+ 97

Road-runner ô taken 11 A. M. in October, immediately after being shot.......... $107.4 \quad 78$

White-crested Turaco (Turacus corythaix), in captivity, $3: 30$ P. M. . . . . . . . . . $104.2 \quad 97$

Ara oratrix, in captivity, noon, Sept...... $102.6 \quad 78$

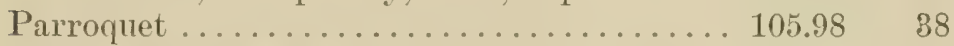

Para Motmot (Motmotus paræensis) in captivity, $3: 30$ P. M................ $104.1 \quad 97$

Barn Owl. . . . . . . . . . . . . . . . avg. max. 103.46167

Long-eared Owl $\hat{o}$ directly after being shot, 1 P. M. May 2................... 104.2 182

Long-eared Owl, taken alive, June, 2 P. M. . $103.3 \quad 78$

Long-eared Owl o directly after being shot, 1 P. M., May 2.................. 103.4182

Owl (Tawney?) ................avg. max. 105.08 167

Owl (Tawney?) ................. mav. max. 106.0167

Saw-whet Owl, in captivity, $3: 30$ P. M.... 104.3 97

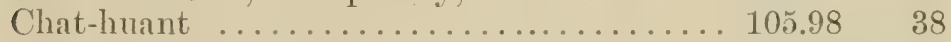

Owl (Horned?) .................avg. max. 105.98 167

Owl (Horned?) ................. avg. max. 106.0167

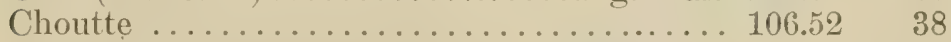

Western Nighthawk, taken in daytime, July, after being shot............... $104.2 \quad 78$

Swift (European?) ................. $111.2 \quad 156$

Western Hairy Woodpecker ô $3 \mathrm{P}$. M., August, after being shot........... 105.5 78

Downey Woodpecker, in captivity, $3: 30$ P. M. ..................... 108.3 
Williamson's Sapsucker $\circ$ alive, 4 P. M.,

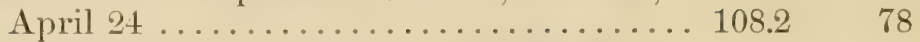

Red-headed Woodpecker o 5 P. M., July, after being shot.................. 107.2 78

Ant-eating Woodpecker ô 3 P. M., October, after being shot.............. 106.6 78

Lewis Woodpecker o 4 P. M., August, after being shot. . . . . . . . . . . . . $107.0 \quad 78$

Western Flicker ô 5 P. M., August, after being shot...................... 106.6 78

Western Flicker $q$ taken alive Sept., 3 P. M. .......................... 106.4

Passerine birds.............107.6 to 111.2

Hammond's Flycatcher ô noon, August, after being shot.................. $106.2 \quad 78$

Grieve commune.................... 109.4 38

Thrush (Sp?)................avg. max. 108.86167

Thrush (Sp?) .................... 109.0 156

Fieldfare ........................ $110.6 \quad 156$

Redwing ........................ $109.9 \quad 156$

Song Thrush..................avg. max. 108.2167

Catbird, 2 P. M., in June, immediately after being shot.................. 106.4 78

Curved-billed Thrasher of 3 P. M., in October, directly after shot............ 107.4 78

Water Ousle \& 3 P. M., in July, directly after shot ....................... 106.4

Swallows $(\mathrm{Sp}$ ?) ...................... 111.2

Bohemian Waxwing o alive, after struggling, 5 P. M., March 5.............. 107.2

Bohemian Waxwing o directly after being shot. $5: 30$ P. M................... 106.2

Bohemian Waxwing o directly after being shot, $5: 00$ P. M.................. 107.8

Bohemian Waxwing ô directly after being shot, $5: 00$ P. M. . . . . . . . . . . . . . . . 108.0

Warblers $(\mathrm{Sp}$ ?) ...................... 109.4

Audubon's Warbler, 6 P. M., May 7....... 108.6

White-rumped Shrike o 4 P. M., August, directly after shot.................. 108.4

Rocky Mountain Nuthatch \& 1 P. M., August, directly after shot. . . . . . . . . 107.0

Great Titmouse.................. 111.2

Greater Bird of Paradise (Paradisea apoda) in captivity, 3 P. M. ......... 106.7 Magpie, juv., alive, 4 P. M., July . avg. of five 106.5 Long-crested Jay, noon, July, directly after shot ......................... 108.4 
Arizona Jay \& 4 P. M., October, directly after being shot................ $109.0 \quad 78$

Sooty Jay (Psilorhinus morio fuliginosa). in captivity, $3: 30$ P. M............ 110.t 97

Jackdaw …................. avg. max. 108.86167

Jackdaw ô. . . . . . . . . . . . . . avg. max. 108.4 167

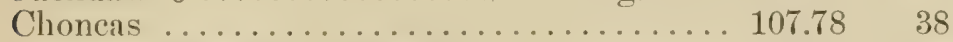

Corbean (Raven or Crow?) ............ $109.22 \quad 38$

Starlings ................... avg. max. 109.25167

Rocky Mountain Creeper o 3 P. M., July, directly after shot.............. $108.2 \quad 78$

Thick-bill Red-winged Blackbird 오 5 P. M., directly after shot............... 109.0 . 78

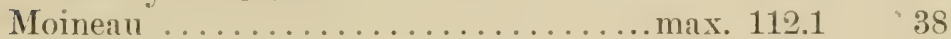

Moineau .......................min. $105.8 \quad 38$

Western Meadow Lark ô directly after being shot, March 4, noon............. $107.2 \quad 175$

Sparrows. (Sp?) ..................... avg. $109.0 \quad 10$

Bouvieuil .................... 107.96 38

House Finch 옹 P. M., alive........... $108.3 \quad 78$

House Finch $\hat{\delta}$ directly after being shot, March $4,10: 30$ A. M............... 106.0 175

Pine Siskin ô 2 P. M., July, directly after

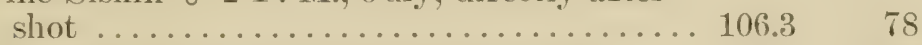

Sparrow (Sp?, probably P. domesticus) ..... $107.8 \quad 156$

English Sparrow, avg. 11, alive, 4 P. M., July $108.3 \quad 78$

English Sparrow ㅇ avg. 6, alive, August... $108.0 \quad 78$

English Sparrow $q$ avg. 2, alive.......... $108.1 \quad 78$

English Sparrow o June 11th, directly after being shot................ $109.4 \quad 78$

English Sparrow of alive, January 26th.... $109.0 \quad 78$

English Sparrow of alive, August......... $107.8 \quad 78$

Chestnut-collared Longspur ô October, directly after shot............... 109.6 78

Western Vesper Sparrow, 4 P. M., October, directly after shot............... 109.0

Western Vesper Sparrow ô directly after shot, April 24, 5 P. M............ 108.6

Bruant de niege................. 109.67

Shufeldt's Junco $\hat{\sigma}$ directly after being shot, noon, January............. 107.50

Cassin's Sparrow ô 2 P. M., July, directly after shot .................. 108.0

Spurred Towhee $q 1$ P. M., July, directly after shot .................... 108.0

Lark Bunting, in captivity, 3 P. M........ 110.†

Bruant ......................... 109.04

Yellowhammer ................ 109.8 
There are several conflicts in the published records on bird temperatures which are probably due to differences brought about by season, sex, struggling, and, too, in the early records, by imperfect instruments, for the modern accurate self-registering clinical thermometer was unknown to Milne-Edwards and his predecessors, its substitute being a crude affair, and such as it was, only just beginning to be issed in physiological and clinical investigations.

Sutherland (112) concluded fiom his study of bird temperatures that "the result seems to show that the higher the bird in the zoological scale, the higher in general is the temperature of the blood"; in other words, as birds have risen in the zoological scale, their temperatures have become elevated pari passu. In general, this conclusion is substantiated by Table No. 6. If the writer is not in error; what occurs in the whole class Aves is also found more or less within the orders and families of the class-i. e. differences of "highness," both in taxonomy and of temperatures, in orders and in families; if this be true, a steadily rising curve of the temperatures found in the class Aves would not only be unexpected but it would be suspicious.

What one would anticipate under these conditions is a more or less steadily rising curve, subject to undulations which are brought about by differences of temperature in the families of the orders involved; this anticipation is realized to a reasonable degree by the temperatures in Table No. 6, which show a distinct tendency to rise with the species, and be subject to undulation when the linear classification jumps from family to family. It seems to me that there is more than chance in the parallelism between the rising body temperature and the bird's elevation, despite the scanty data, and despite the probable errors in both the data and the classification.

Let us see if any other writers have been convinced of this relation; Pembrey (156) says, "those animals which are higher in the scale of evolution, such as birds and mammals, have a high temperature, which is fairly constant and independent of the temperature of the surrounding air."

Simpson (165) seemed surprised to find that different families of the same order exhibited different temperatures, saying, "even families of the same order appear to differ considerably in body temperature," which, rather than a surprising thing, is what ought to occur if Sutherland's law be correct and apply to orders and families as it seems to apply to the class. "Simpson appears to have been familiar with Sutherland's conclusion, and after denying that there is a relation between the highness of a mammal and the elevation of its temperature, he salys that "the same appears to be the case amongst Class Aves, above the Ratitr." I take 
it that he based this adverse conclusion on his own work, which included the "Turbinares. Staganopodes. Prgopodes, and Longipennes," a group of families forming bit a small per cent. of the Class, and also taking in birds largely of the lower levels. Furthermore, he based his conclusions (seemingly) on the mean of the temperatures of the species in the family, which seems untenable, if it be true (as he points out) that there are differences of temperature amongst the families of the orders, and the more untenable if the species within the family also show different temperatures. Simpson also based his conclusions on the average temperatures of the twenty-four-hour period, which I feel is not correct; unless I am much mistaken, man's normal temperature is regarded as the average of the highest in twenty-four hours, $i$. $e$., that taken between noon and six in the afternoon, and such is the methor I have utilized, when possible, in my consideration of this phase of this study. I am strongly of the opinion that grarluations of temperature occur primarily in the class, secondarily in the order, and again in the family; what occurs in the whole avian tree is repeated in the secondary, tertiary, and even smaller branches.

Seeking to confirm these ideas on grounds other than those of these meagre records, one may justifiably ask, are there any other facts (or reasons) which can point to, or explain, the assumed co-existence of "high temperatures" in "high birds," and "low temperatures" in "low birds?"

It is not possible here to go extensively into the question of the physiology of animal heat, but it can be examined briefly at one or two points where it applies to the ideas now in hand. It has been shown (148) that, with all mammals investigated up to date, each animal can go through only a definite and fixed number of metabolic changes during its period of post-embryonic development, a contention based on the fact that all such mammals consume equal total numbers of calories per kilo of weight, from birth to maturity; there are further indications that this ratio may also obtain through the whole period of life. These facts mean that the large mammal, which in general lives longer than the smaller one, goes through its chain of metabolic changes slowly, taking a long time to do so, while a small mammal does the reverse, using up its metabolic-change quota (which is identical in both mammals) swiftly. The large mammal lives long and slowly, the small one briefly and swiftly, a difference in "swiftness of life." What is known as to a correlation between size and longevity in mammals tends to confirm this theory of the "swiftness of life," for in the scale of size represented by the elephant, camel, dog, and mouse, variations in size and longevity are found to go hand 
in hand. Another way to put this view of the swiftness of life is that the rapidity of growth from birth to maturity is proportionate to the metabolic intensity, which last is, as said before, directly related to size; the elephant takes years to mature, the mouse can breed at the age of a few weeks. This difference in the speed of life process in large and smaller animals is not based on theory, but is demonstrable by experimental methods $(156)$, all of which show that the metabolic intensity is proportionate to the animal surface area, which is relatively larger in the smaller mammals (148). Hand in hand with this slowness or swiftness of metabolic processes are found corresponding differences in the animal's physiology, particularly in the respiration, heart rate, temperature, and possibly in the cmbryomir metal, olism. There are some indications at hand suggesting that this relation of swiftness of life and body size prevails in the embryonic, as well as in the post-embryonic stages of existence. There is suggestive evidence that the larger the mammal the longer is its gestation period: with the monse it is three weeks and with the elephant at least eighteen months, and animals intermediate in size show a fairly welldefined intergrading in the gestation period length. Pembrey's remark that "the temperature of the smaller mammals and birds is often higher than that of the biggest" (156) gives a logical introduction to the question, Does this relation of size and swiftness of life in mammals obtain also with birds? Simpson (166) has definitely answered it in the affirmative, so far as the hen is concerned, for he stated that the large and most lethargic birds ( $i . e$., of hens) had a much lower temperature than the smaller and more active ones. I am convinced that a thorough study of avian physiology will show the same variation in the swiftness of life in this class as is demonstrated in mammals. It seems quite likely that increasingly intense metabolism and steady dimimution in size of birds are related, and that the intense metal,olism finds expression in many other ways in the function of birds. For example, I have found a house wren's respiration to be 160 per minute, and that of a house finch to be 100 . Rapid respiration and fast heart rate are always (in health) co-existent; if one take the respiration: pulse rate index of man, $i . e$, one to four, and apply it to these two species, it would show the wren to have a pulse of 640 , and the finch, one of 400 beats per minute. Since there seems little known about a bird's minute physiology, it might be hazardous to assume that the human index can be correctly applied to birds. However, there can be no question as to the amazing rate of the heart beat in birds; if one hold an English sparrow or any small bird loosely but securely and gently in the hand, and apply it closely to one's ear, the bird's heart, as it 
beats, sounds like the rapid tick of a small watch*. All these observations merely point to the exceedingly intense metabolism and swiftness of physiologic processes in such small birds, a combination of enditions that should produce high body temperatures in small birds, and a brief study of Table No. 6, shows clearly that the birds with highest temperatures are, as a rule, the smallest of birds; moreover, it is held by physiologists (151) that the power to produce heat is proportionate to the activity or sluggishness of the animal (not specifying class). These facts again lead to a belief in the general correctness of Sutherland's law as to 'low' and high temperatures in "low and high" birds. There are some relatively small birds which have low temperatures, as, for example, the apteryx. It seems to me that this is a good example where it is not size but the primitive character of the bird which determines the elevation of its temperature, but this is not proven; it may be a true exception, or the low record may be due to errors of observation. It is to be noticed that one record of a pigeon, the speckled pigeon, shows a very high temperature for a bird classed as relatively low; the whole of the facts in this, and similar cases, are not known, and compel again one's suspending final judgment pending further light.

In further support of the relation between elevation of temperature and taxonomic standing, it may be recalled that as birds have grown up, and away, from their proto-avian, or proto-reptilian ancestors, they have become better and better feathered, and feathers are said to have made birds what they are, the warmest-blooded creatures in existence, whence it follows that the farther they have traveled (without later recession) from their primitive ancestry, the more elevated have become their body temperatures. It seems to me that weight of evidence supports Sutherland's hypothesis, and for the purposes of this discussion it is held to be true.

Now, if one holds that birds' temperatures are more and more elevated as the species is higher and higher in its phylogeny, one may ask, does this condition have any influence on the length of incubation? It must here be remembered that it is possible that "swiftness of life" may embrace the embryonic period of birds as it seems to with mammals, and that the specific temperature and the incrbation length are co-ordinate, assuming this to be true for the moment

* Since the above was written I have learned that Buchanan (174) has determined the heart rate in several bird species, using the electrocardiagram method for its detection. His results are almost incredible, and show most strikingly the wonderful metabolic activity of birds, especially the small species; Buchanan gives the heart rates as follows: fold-finch 900 to 925 per minute, green-finch 700 to 848 , sparrow 745 to 850 , pigeon 141 to 225 , hen 304 to 345 . 
on hypothetical grounds alone. Thus, this relation of metabolic intensity, size, and length of incubation may account for the loose relation known to exist between a bird's size and its incubation length, a relation admitted in the discussion on that theory. It seems to me that there is direct experimental evidence of the effect of differing temperatures on the incubation length; it has been shown that an optimum temperature is the most important of the three factors necessary to successful incubation, and that this optimum emanates from the incubating parent, and that with hens' eggs, their usual minimum duration of incubation can be shortened a few hours by carefully raising the temperature of the incubator a little above the usual optimum, which is identical under the hen and in incubator practice.

Until evidence is fortheoming to show that these two conditions do not apply to all other birds' eggs, it seems tenable to believe that as birds have slowly risen in evolutionary height, their temperatures have also been correspondingly elevated. and that these increasingly higher temperatures have gradually shortened the periods of incubation. What occurs with a hen's egg during one incubation period through a slight elevation of the incubator temperature. has talien place in lesser degrees, in mature, for countless bird generations; each increment of temperature elevation. howerer slight, added by ach succeeding ascending generation. has correspondingly influeneed the length of incubation, alwars resulting in some shortening. This process has been, probably, exceedingly slow, consuming ages in acemmulating a patent change, both in the borly temperature and in the inculation perionl yet, in the encl, as we see it today, it has strept on with striking results, the Passeres having forged ahead, through their very high temperatures, to a fourteen-day period, while the ostrich and other birds with low temperatures are marooned at forty-two (or more) days. From the foregoing it seems, to me, impossible to

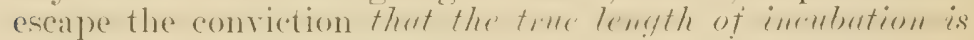
fixed or determined by the temperature of the incubating parent, long with low temperatures, and brief with high temperatures. Inasmuch as there is a goodly amomit of support to Sutherland's Iaw of low temperatures with "low" birds and higher temperatures with "high" birds, I would tentatively enunciate the idea that the true length of incubation is determined by the bird's position in the avian scale of life, basing this hypothetical law on the assumed relation of temperature elevation to incubation length, and of temperature elevation to the species' position in avian taxonomy.

If the various data collected together in this study are now to be examined and interpreted from the viewpoints 
just enunciated, it becomes necessary to arrange the species aflected, according to some reasonably acceptable classification. It was with hesitation that I approached this question of classification, and when the data finally had to be classified, I wrote to several of my professional ornithological friends, requesting their opinion as to the best present avian classification. All, as a unit, expressed themselves virtually in the words of one who said, "There is no best classification," saying further that the arrangement of avian taxonomy as given by Gadow, and slightly modified by Kinowlton (10), was as good as any, which is the one followed in listing the incubation periods, and in the secondary tables and lists given in this study.

In speaking of a species "lowness" or "highness," I do not overlook the many difficulties attendant upon a determination of these levels. What I really would like to know, viewing the question from the standpoint of this discussion, is how far has a given species traveled from its proto-avian ancestors, and not how much has it specialized. No linear classification can show this, however perfect our knowledge may be, nor can it exhibit the true positions of species in one family in any given order as levelled with species in a family in another order, nor yet can it give an adequate idea of the relation of species of different families in the same order. Many inconsistencies and contradictions appearing under the present explanation of what controls the tmie length of incubation are possibly due, not only to lacune in our knowledge, and to errors in the records of incubation lengths, but also to the shortcomings of a linear classification. In other words, incorrect taxonomy, and the inability to properly depict the relation of species in one order to those in another, result in what appear to be serere dislocations of ineubation lengths from positions one would assign to them under the present explanation.

Within natural groups (or families), the incubation lengths should be more or less characteristic because the members of such groups have diverged but little, inter se, and being less plastic than many other character's, the incubation length, under these circumstances, would diverge still less, resulting in a condition substantiating Evans' (2) first conclusion, to-wit, that natural groups (or families) have incubation periods more or less characteristic to such groups, a conclusion borne out by the incubation length data given in Table No. 1; the gradations in some families between the accepted taxonomic positions assigned to the species correspond surprisingly closely with the variations of incubation length of the same species, especially if in such families the largest species are ranked as lorrest. If all families be so arranged, the undulating curve of incubation 
lengths becomes still more striking in its trend upward as the species also trend upward.

Despite the difficulties inherent in a linear classification, and the errors and conflicts in the incubation records, these records show clearly that the incubation period becomes shorter as the species mount the avian tree; it is possible that a rearrangement of the species according to some other classification might alter the curves radically and make other interpretations necessary; it is equally possible that a rearrangement might strongly fortify the present conchusions. Time and space forbid trying other classifications or eombinations. It is obvious that the list of incubation periods shows also that birds, in general, grow smaller as one follows their life scale upwards, a fact which accords with the suggestions as to "swiftness of life," size, and temperature. One must not overlook the possibility that the character of "swiftness of life" embraces the embryonic period (incubation) of life with birds, as it seems to do with the embryonic period (gestation) of mammals.

There is much to sustain the belief that the intensity of metabolism and the speed of embryonic development are correlated (155), but the details of this evidence cannot, however, be given here. That size and temperature are more or less correlated both with mammals and birds is unmistakable; that size, temperature, and taxonomic standing are all parallel is not so evident, yet it looks as though the lower birds are the larger ones, and that the tendency to become smaller and to have shorter incubation periods, as the avian tree expands upward, is fairly obvious. There is some geologic evidence pointing to the probability that ancient birds were generally larger, a fact well brought out by the large size of birds recently found in the California asphalt deposits; however, some living birds are small yet "low" in degree, $i . e$, the kiwi, and some ancient birds were small yet close to the reptile in some ways, the ichthyonis. for example. This question of "lowness" or "highness" in birds, in the present discussion, is a question of how far has a given species journeyed away from its proto-avian stem, since it seems probable that the farther a bird is from its primitive ancestry, provided it does not later degenerate, the higher will be its temperature. I doubt very much that the present mainstays of taxonomy can alone measure this space between pro-bird and super-bird. I believe that future students of avian taxonomy will have to give more consideration, not only to embryology, but also to bird physiology, in order to correctly locate and plot the mile posts in a bird's taxonomic journey.

On the other hand, experimental evidence demonstrates that the usual length of incubation may be elongated by dif- 
ferent bird temperature conditions, for it has been shown (162) that the eggs of the Egyptian goose hatch under a common hen in twenty-eight dars. and under a muscory duck in thirty days. One more suggestive contribution to the experimental evidence going to support the connection between temperature, size, and incubation length can be given here; Milne-Edwards (38) proved "that abnormal elevation of incubation temperature during the first period of incubation tends to diminish* the size of the chick. and to produce dwarfs, though shortening the period."

If it be assumed that birds have in general grown smaller as they evolved upward, the question can be interpolated here (in fact, it can be considered the "acid test" of the truth of the assmotion). have they benefited by their smaller size? It would seem so, since the efflorescence of the avian tree is made of the Passeres, practically all of which are very small. Perhaps the diminishing size of birds steadily accelerated their metabolic speed, which elevated the body temperature (or vice versa), and initiated a physiologic cycle, which is still revolving in ever diminishing circles.

If a rise of temperature in an artificial incubator can diminish the size of the chick. and shorten the incubation period, is it impossible to have the same thing happen in nature? Because one cannot see or measure the slight decrease in size, following an equally slight elevation of temperature in a given species, is it not, however, possible that thousands of such slight elevations of temperature, and of such minute reductions in size, can be cumulative, and end in results which are seen as existing conditions of today. It seems to me not only possible, but highly probable.

For the sake of convenience, I will term the explanation, (just elaborated), of factors fixing or controlling the true length of incubation "the temperature and ascent theory." A careful search through literature has disclosed but two hints that avian "lowness" or "highness" might have some effect on the incubation length. Both are more or less indirect, and the first is given in a few words by Fürbringer (102), who apparently considered this explanation, only to reject it by saying, "Thus the number of incubation days, which arranges itself more according to the size of the egg and bird, than to the relationship boundaries, can be of no great taxonomic" significance," with which conclusion I cannot concur; the second is a suggestion made by Gadow (150), who held that the developmental period (embryonic plus nest life) stands in direct relation to the degree of "lowness" or "highness" of the bird, and that the "highest" birds

*Italics by W. H. B. 
have the shortest incubation periods; so far as I am able to grasp Gadow's words, he correlated this shortness of inculation with no definite physiologic process, and spoke of it only incidentally in a discussion which related to the question of a bird's being precocious or altricial. Arrigoni (12) comes nearer to the final conclusion enunciated in this discussion, when he speaks of the length of the period of incubation as being related to the vitality (sic) of the bird. I am sure many others have grasped this idea, but I have been wholly unable to locate any written statements to such efiect. These, then, are all the hints, direct or indirect, which suggest a possible relation of a bird's taxomomir stancling to the length of its incubation period, that I have been able to discover in the ornithological literature at my command.

The evidence and data which I have been able to collect, point to the irlea that the true length of incubation yields to change exceedingly slowly and with difliculty, much more so than characters of more recent acquirement, as color, size, etc. It is almost self-evident that the incubation periods of birds have been gradually shortened and that they are still slowly yielding, as in the past, to the influences outlined in the foregoing, and will continue to do so until this process of abbreviation becomes detrimental to the species. I am firmly convinced that, once a given period becomes shortened, it remains so, becoming longer again only apparently, and through such infuences only, as slow or temporarily suspend the embryonic development. and returns, either in the next set of eggs, or with the first set of the next generation, to the previous normal, after the warping influence ceases. Once a specie rises in "taxonomy," and has its temperature coincidentally elevated, which shortens its incubation period, this latter will remain constant under optimum conditions, even though the species later retrogrades morphologically. I believe that in this case, the bird remains physiologically stable, at the previous level, though its co-existing norphologic level will have been lowered, and that the bird will then have an incubation length which, under the present theory, would appear shorter than its morphology would predicate. On the contrary, a species may "specialize" morphologically, appear as "high." yet remain at the pristine lower physiologic level, and have, as a result, an incubation period longer than one would presuppose for it, judging from its morphology.

I am inclined to believe, as a result of this investigation alone, that there are physiologic as well as morphologic levels to be considered in taxonomy, and that these levels may differ in the same indiviclual. I am convinced that there is a large and profitable field to be explored, in this question of the possible differences in physiologic and morphologic 
levels of taxonomy. The length of incubation with the ostrich, and its temperature, would indicate for this species a higher physiologic level, taxonomically, than does its anatomy indicate for its morphologic level. It is higher physiologically than morphologically.

Whaterer may be the final decision as to the relation of a bird's "lowness" or "highness" to its length of incubation, I am convinced that there will be but one conclusion as to the correlation of incubation temperature and the length of incubation, and that it is highly probably that. ultimately, the last word on this question will have to be said through determination of temperatures taken between the eggs and under the incubating parent (real or foster).

\section{Collateral Evidence}

Perhaps some additional light can be thrown on the theory in hand, through a review of the incubation conditions which prevail amongst birds' nearest relatives, the reptiles, and by a scrutiny of the effects of temperature on eggs other than those of birds and reptiles. H. Milne-Edwards (38) states that the period of incubation of silk-worm eggs can be prolonged to fifty days if subjected to low temperatures, that they hatch in thirty-four or thirty-six days if kept at a temperature of from $77^{\circ}$ to $86^{\circ} \mathrm{F}$., and in sixteen to eighteen days if they are maintained in a temperature of $86^{\circ}$ to $95^{\circ} \mathrm{F}$. Though it is true that these eggs belong to a creature in a class widely separated, and rery divergent from the Class Ares, it is still quite suggestive that with them is found a high grade of elasticity in the length of incubation, which is governed by variations in the temperature conditions; this is mentioned to illustrate how potent an influence variations in temperature can have on embryonic development. The close relationship between reptiles and birds warrants a careful examination of the facts touching on incubation of reptile eggs; it is highly possible that the incubation of such eggs is subject to the same variety of control as those of birds, and that the same "temperature and ascent" theory applies as well to reptiles', as to birds' eggs. In line with this thought one may recall that the evolution of "parental care" shows a series of steps from low to high, broken it must be said, however, by striking exceptions; the evolution of parental care is well seen in reptiles and birds, taken as a whole, and has been said (155) to be associated "with the need of higher temperatures for development."

Reptile eggs, in all probability, have a normal minimum duration of incubation, which may be peculiar to each genus, i. e., a specific incubation length; such eggs withstand successfully a much longer and some a far more severe chilling 
spell than do those of birds, and they may bear, velatively higher temperatures, $i$. e., the tuatara lizard's eggs $77^{\circ} \mathrm{F}$. (12(i): they probably remain viable for far longer periods, their embryonic development persistently proglesses at much lower temperatures than does that of birds, and one would predict, on these grounds, an exceedingly variable and elastic apparent length of incubation, which is borne out by the facts in the case. No reptile incubates its eggs, unless the devoted care given by the female python to its eggs can be so classed; this may, however, be a true but primitive kind of incubation, a real beginning in the scale of incubation habits, since it has been shown that a python's body temperature rises $10^{\circ} \mathrm{F}$., above the surrounding air while covering its egos, and Heilmann (118) says the temperature of a "quiet inculating snake" is about $50^{\circ}$ to $5.3 .6^{\circ} \mathrm{F}$. If reptile eggs respond to the same controlling influences as do those of birds, it is possible that data on reptile incubation will disclose such correlation; I have discovered a few facts, which. while not nearly as numerous as might be desired, are nevertheless quite suggestive. If I read aright, it appears that the most primitive of all living reptiles is Sphenodon punctatus, and on grounds outlined in this discussion, its incubation period should be the longest of all living reptiles, and it is, lasting from twelve to thirteen months. reckoning from laying to hatching. It is necessary to recall, that about five months of this period, extend over the New Zealand winter, and that during this time the embryo ceases to develop, and hibernates in ovo, as it were, until the environmental conditions again become such that it can survive when hatched.*

The next longest period of incubation amongst reptiles is that of the European tortoise (Emys orbicularis) which is probably a higher reptile than Sphenodon, though it is placed in an order ranked below that of the Sphenodon; in southern Europe the eggs of this tortoise hatch in five to six months, while in northern Russia (120), they require eleven months; a large part of this eleven months is the season of Russian winter, and during its intense cold, the developing tortoise embryo is in a condition of suspended animation yet, deducting this time from the whole period of incubation, the actual developmental period is still next to the longest amongst reptiles. Then comes the alligator, and in this instance one is on secure ground in having a

*It is possible that this reptile, which has persisted almost un. changed since the Lower Permian, survived because it was able to adjust, so to speak, its incubation to comparatively low temperatures, which may have supervened in the course of geologic changes, and which exterminated the then existing host of its huge contemporaries (dinosaurs, etc.), whose probable long incubation periods required an equally long period of relatively high temperatures. 
record which has been checked frequently by eggs placed in an artificial incubator, where they require sixty days to hatch. The measuring of the true length of incubation amongst other reptiles becomes more and more perplexing as one takes up the succeeding ascending orders. It is exceedingly difficult to decide what is the true length of incubation with many snakes and lizards because of the ease with which the embryonic development of these animals can be slowed down, or temporarily suspended, and because of the high probability that the same reptile species may exhibit all gradations between complete oriparity and oroviparity, gradations which can cause a difference of days or even weeks in the apparent length of incubation in the same species. This possibility also is mentioned.here because it is probable that oviparity and ovoviparity are interchangable according to environment, in certain other species.

This causes a wide variation in the records of incubation lengths of repriles, and adds to the difficulty of reaching conclusions on the point now in mind, ret in spite of this and the paucity of records, it seems to me that reptiles also exhibit a tendency to shorter incubation periods as the species is higher in its scale of life, which tendency seems to show in the data given in Table No. 7 .

TABLE NO. 7

\section{Incubation Periods of Reptiles}

Period Authority

Green Turtles.................. 81/2 weeks 119

Loggerhead Turtles................ 81/2 weeks 119

European Tortoise...........20 to 44 weeks 120

Tuatara Lizard................. 52 weeks 121

Crocodile .................... 12 weeks 120

Alligator (in incubator) ...........8 81/2 weeks 122

Common Swift.............6 to 8 weeks 123

Python reticulatus..........6.6 to 8 weeks 125

Python molurus................ 10 weeks 120

Black Snake................. 81/2 weeks 123

Fox Snake............. $3 / 7$ to $86 / 7$ weeks 123

Corn Snake................6 to 8 weeks 123

Yellow Rat-snake................ 11 weeks '123

Ring Snake................. $56 / 7$ weeks 123

Milk Snake................. $81 / 7$ weeks 123

King Snake................6 to 8 weeks 123

Coral Snake........... $82 / 7$ to $84 / 7$ weeks 123

If reptile eggs vary in incubation lengths according to the applied temperatures, it is proper to ask if there be any evidence in the temperature of reptiles, showing trends similar to those in birds; reptiles are said to be "cold-blooded," but it can be shown that this term is only relative. The average 
temperature of reptiles with weak respiration is $1.8^{\circ}$ to $5.4^{\circ}$ F. above the circumambient medium, and for others the following degrees have been given:

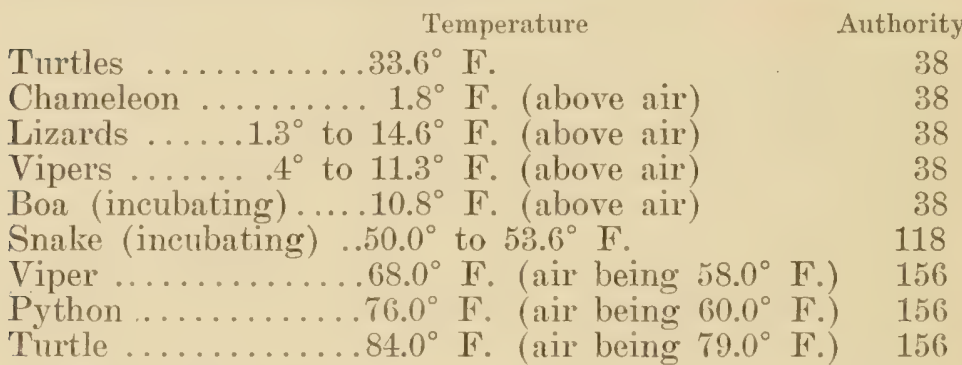

The fact that the male boa, which does not incubate, has a lower temperature than the female (156) is worth noting.

There is shown in the figures just given (see Table No. 7) enough tendency for the temperatures to rise as the species gets "higher" in its life scale to give color to the possibility that with reptiles, as with birds, the temperatures and the species becone elevated concomitantly. From the "swiftness of life" point of view, it is interesting, and perhaps important, to note that the quict. shogrish reptiles have lower temperatures than do the active ones.

A relationship between reptiles and birds, should, and does, leave in both, traces of a common ancestry; can one find indications of this in the incubation periods of birds? If the length of incubation in birds be, as I am convinced it it, a deep-rooted, inelastic and inherited characteristic, it should exhibit some proto-reptile or some proto-reptile-hird peculiarity or peculiarities; the data show, both with birds and reptiles a decided tendency to arrange themselves in groups of periods having a septenate multiple, $i$. e., 14, 21, 28,42 and 56 days. This septenate tendency has been explained on the hypothesis that it is an inheritance from ancestors which were aquatic, and subject to, and probably modified by, maximal tides every twenty-eight days. If this be true, it would bespeak an amazing tenacity in the persistence in birds, of this very ancient character. It may not, however, be a correct explanation, because the same septenate or monthly spacings are to be found attached to the functions of mammals, $i$. $e$, gestation and rut. It does not seem possible that such an old influence should have left an impress which is visible in a stem so far removed from the main trunk as is that of the mammal branch.

\section{Taxonomy, the "Ascent Theory" and the Data}

I know full well that real and apparent inconsistencies and conflicts will be found in the correlation of these three, 
when the present data are viewed from several different points. Some come promptly to mind : according to modern taxonomists, the megapodes are near relatives of the domestic hen, and they should have, by this tolien. a length of incubation somewhat similar to that of the hen, yet it is in reality much longer, and far longer than one would predict. from iny point of view. with birds of the comparatively high standing of the megaporles. Hence their incubation length does not seem to fit in with this "ascent theory ;" how it fits in with the temperature sicle of the present explanation I do not know, as I have no temperature records of these queer birds. What are the possibilities in the premise? These birds may upset the whole argument, or they may be one of a few exceptions, or there are two other possibilities. It has been maintained in this discussion that the true length of incubation is fixed by the parent's temperature as applied to the eggs; thus this method of fixing cannot apply to the megapodes because their egos are hatched, not by heat supplied by the parent bird. but by that arising in the decaying mound, its temperature being given as 95.0 to 96.0 F. (131), which are the lowest successful incubation temperatures, for birds' eggs, known to me. It might be assumed, in the first place. that the mound incubation habit is very ancient, dating from the time when the megapodial ancestors were much less removed from the pro-bird than at present, and that the ancestral species had at that time, a comparatively low temperature, approximating that of the present incubation mound. If the mound building habit arose at that time, and continued to the present, it would explain the inappropriately long incubation because, on this last assumption, it has not varied during all the past ages. notwithstanding that in the interim there have been great change and variation in the morphology of the group. The eggs have, during all this time, been hatched by a temperature which has varied little. if at all, resulting in an unchanging incubation length. On the contrary, it is possible that this mound incubation habit is of recent origin, and that the present recorded megapod length of inenbation is an apparent one only, being the true length plus $\mathrm{X}$ davs of slowing down of embryonic development caused by the low temperature of the mound; it is difficult to picture just how, under this suggestion, the eggs successfully became adapted to such abnormal prolongation of incubation. This might be tested experimentally by subjecting megapode eggs to varying temperatures in artificial incubators; it also would give an added light if one knew what is the true length of incubation of the genus Maleo, since eggs of this genus are said to be incubated. not in mounds, but by the sun's heat or by hot springs. The case $0_{1}^{z}$ the megapodes falls without the confines of my 
present theory, as regards taxonomic standing, but within the control of the temperature explanation. The incubation length of the flicker, not a very high, or a small bird, is given as eleven to twelve days, which seems unduly brief in the light of this study. This short period (if it is correctly estimated) may be due to temperature conditions, since this species nests in tree holes, where there is little heat loss, and lays a large complement of eggs, which, as they develop, would tend to higher and higher temperatures as the embryos grow. With other hole-nesting species laying few egrs. this latter effect is not present, an absence which may help to account for longer incubations with these species.

What has happened in the case of parasitic cowbirds and cuckoos since their eggs are incubated by foster parents? In answer to this problem will only be had when the temperatures of the parasitic birds and of their dupes are known, as well as the temperatures of such cuckoos and cowbirds given to autogenous incubating. It is not too late to learn the last, as there are still some of the species of these genera which incubate their own eggs. In the development of this parasitic habit, it undoubtedly was at first a "hit or miss" arrangement; if the parasitic eggs were given too high heating by the foster parents, their embryos died, and the reverse could also be true, though an incubating temperature slightly helow the optimum might result in a successful, but prolonged, incubation. Such a "hit or miss" method, after repeated trials through a long stretch of time, together with a possible tendency of the female cowbird to return, when mature, to a nest similar to that in which it was raised. would eventuate in a variety of selection, which would secure a large percentage of successful incubations. The cuckoo is said (110) to lay egos which are. proportionately to itself, the smallest of all birds' eggs; has this arisen because of the possibly higher temperatures of the foster parents?

What happens when a quail's egg is hatched by a bantam hen, or what would happen if a magpie's eggs were placed under a bantam?

It seems difficult to reconcile a mourning dove's incubation period. which is said to be fourteen days, with that of the robin's of equal length, because taxonomists are agreed that the latter is a much higher bird; perhaps both of these species have trareled, physiologically, equally far from the pro-avis ancestor, but along quite divergent roads. The ostrich is regarded, by most classifiers, as lower than the emu, yet its incubation period is not as long as that of the latter. This example may not be a real conflict with the present "ascent theory," but the lack of concord may be due to an error in taxonomy, because at least one ornithologist 
(120) believes that the emu is a lower and a more primitive bird than the ostrich, and his classification is supported by the position taken in this paper, $i$. e., that the longer is the incubation period, the lower is the bird. The secretary bird is believed to be a primitive survival, not greatly changed, from its pro-hawk-heron ancestor: if this be correct, a long incubation period would be predicted. viewed from the "ascent theor'y," a period as long, or longer, than all of its near relatives. and such is the case (barring one or two questionable exceptions). 'These and similar questions must be decided by experimental work; they are but a few of the many fascinating ones uncorered by a study of the length of incubation.

It is possible that many conflicts, and inconsistencies in this new theory, will be cleared up when the present incubation records are checked and corrected by new observations, undertalien to eliminate, or allow for, the conditions which (1) parently increase or decrease the true length of incubation, and when a method of recording avian classification will have been devised which does not project the vision of the mind's eye along a single line, and which will graphically portray the relation of genera to genera, irrespective of family, or order. Perhaps such a three-dimension demonstration scheme is impossible of attainment.

The chances of any given explanation being correct are larger if the results it foreshadows can be shown to be beneficial: if the bird's taxonomic position, temperature, size, and length of incubation be correlated, it is pertinent to ask, has the combination been beneficial to the race? It would seem so, judging from actual experience in nature, since so large a number of existing species are of the highest levels, have diminished in size, have acquired short incubation periods, have developed high temperatures and have conconitantly flomished and multiplied. Do short incubation periods prove helpful to the species? Is there any adrantage to the robin that it gets its young out of the nest and able. more or less, to shift for themselves in four weeks from the laying of the eggs, while a goose, a turkey, or a red-tail hawk. in the sime time is able to complete only the embryonic development of its young, and has still ahead of it, the long post-embryonic period of derelopment, and all the care incidental to it, plus such post-nidicular time, during which it must give more or less care to its young? Is there any benefit to a species to be able to put two broods of young into the field, while another species can, in the same time, put but one? It seems to me that these questions can be answered only in the affirmative. If it be true that the number of eggs laid in a set is in direct ratio to the dangers encountered by the species $(110)$, it also would seem reasonabla 
to believe that a species would be better able to successfully maintain its status in the face of its daily dangers, throngh the increased prolificity made possible by the short incubation period permitting more, and perhaps equally large broods to mature during the breeding season; this is but another way of making the eges proportionate to the dangers meeting the species in its daily life, and may be looker upon as a result of the higher birds having high temperatures.

More broods each season inflict greater responsibility and labor on the parents; this affects but two, while the greater multiplication of individuals certainly more than counterbalances this. As said above, Gadow holds that the shortened incubation period, and its correlated long nest period (?) reflects benefits on both parents and young; I believe it does help the young, but as to the parents, I am inclined to feel that for them, the beneficial effects are negated by the disadvantage of more labor, wear and tear, etc. In all other creatures, the parent is so universally disregarded, so to speak, for the good of the young, that I am skeptical as to there being an exception with birds. The question also arises of two species, which young are better able to fend for themselves at the end of a given time, viewing the question from the standpoint of the possible beneficial or injurious effects of a short or a long incubation period, those hatched after a short or those after a long incubation! 'Two months after hatching are young robins, or young quail, better able to shift for themselves, and to meet and overcome the perils of their daily life? It seems to me that the advantage lies with the higher bird, because of its shorter incubation period, which supports the belief that the diminishing lengths of incubation delivers benefit to the species. It is self-evident that such a continual shortening of the incubation period as $I$ have assumed to have been in progress in the past, and which is probably still going on, may have for a given species adventages and disadrantages which cannot now be clearly apprehended since some may be disappearing and others only just coming into effect.

If my contention be correct, that the true length of incubation is a fixed and persistently inherited characteristic, and determined by the bird's temperature, and its position in its scale of life, it then becomes possible that this characteristic will be useful as an aid in allocating the correct taxonomic position of a species, taking a place (perhaps a very minor one) with anatomy, embryology, splanchnology, ptilosis, etc.; it seems to me that there are larger possibilities for usefulness in these directions for this character, than there are for such an unmeasurable and indeterminate char- 
acter as the nervous system. which last has been used to place the Corvidre at the apex of the avian tree. If this "temperature and ascent theory" of the control of the length of incubation, with birds, be correct, it will, at least, bring about a semblance of order where before more or less confusion prevailed: if it be fallacious, and untenable, then $I$ can at least hope that this discussion may point out the lines of investigation along which, in the future, ornithologists will hare to work in order to solve what in the past has been an unanswered riddle.

Correct or incorrect this discussion may, I hope, draw attention to the importance of gathering accurate clata on the true length of incubation with birds, and its relation to their physiology and taxonomy.

It appears to me that some of the previous explanations as to what fixes, determines, or controls the length of arian incubation have held more or less of the truth, because they concern conditions which are effects of a single underlying cause, but I believe that there is no experimental evidence whatsoever, that differences in the size of bird, age of female, longevity of the parents, condition of the young at hatching, the size of the egg, or its shell, or the yoll size, or various telluric conditions ever permanently alter the tru.e length of incubation; there is abundant experimental evidence (both accidental and intentional) that variations in temperature can prolong the time of incubation, and can shorten it to a slight extent, and presmmptive evidence that this effect of variation in temperature in shortening the length of incubation. loes in the end bring about the large variety of incubation lengths found with birds today.

\section{Data Needed for Further Study of This Problem}

The prosecution of this study has uncovered a lamentable clearth of information in many phases of the questions at irsue, and in now calling attention to a few of these replorably incomplete chapter's of ornithology. I would remind orvitholngists that in them they will find openings which mill lead to splendid opmortunities for original research in almost unexplored and unexploited fields. fields which may soon be swept out of existence hefore the devastating malch of civilization. Data needed:

Exact length of incubation period of birds and reptiles,

Exact lencth of incubation of bircls in polar and tropical regions,

The period of viability of birds' eggs,

The weights of birds, preferably of the breeding female, The weights of birds' eggs,

The effects of superheating on bircls and reptiles' eggs, 
The optimum incubation temperatures of birds' and reptiles' eggs,

Bird temperatures,

Temperatures under the incubating bird,

Reptile temperatures,

Minutia of bird physiology.

\section{Conclusions}

While final judgment and decision must be suspended on many, if not all, of the points at issue in this discussion, suspended at least until a much larger, and perhaps an entirely rewritten accumulation of data on all of the above questions has been made, I feel justified, at this time, in drawing the following tentative conclusions:

Minor: That

Our present incubation records include the true and the apparent lengths, the latter in the majority, probably,

The srue length of incubation can be shortened (artificially) with extreme difficulty, but prolonged with ease,

The true length of incubation is loosely related to the size of the species, and still more loosely to the size of the egg,

There is little or no relation between the true length of incubation and precocity,

There is no relation between the true length of incubation and the longevity of the species, nor between it and the body-weight: egg-weight index,

There is no relation between the true length of incubation and the age of the female, or the size of the egg yolk,

Condition of the parents, faithfulness of the parents while incubating, viability of the egg. thickness of the egg shell, and influences listed under the head of "Telluric Conditions." have no lasting effect on the true length of incubation: when any of these conditions seem to modify the incubation length, it is merely an action of slowing the embryonic development, and causes no permanent change in the length of the incubation period.

Major: That

There is a true or specific length of incubation,

The true or specific length of incubation is a deep-seated, inelastic, and persistently unchanging (in human time measures) character,

Bird temperatures are closely related to the taxonomic "lowness" or "highness" of the species;

A bird's temperature determines, or fixes, the true length of its incubation period, and that only an abiding change in 
the bird's temperature can permanently alter the true length of its incubation period,

Whence I would suggest the following

\section{Hypothetical Law,}

That the true or specific length of incubation is fixed by the "lowness" or "highness" of the species, particularly by the physiologic "lowness" or "highness," both of which are fixed by the distance the species has traveled (without retreating) from its proto-avian ancestor.

TABLE NO. 1

Incubation Periods*

Family-Species

Period Authority

Struthionidae

Struthio Camelus-Ostrich.........36 to 40 days

Struthio Camelus-Ostrich........45 to 48 days

Struzzo ................50 to 60 days

Ostrich ..................50 to 60 days

Ostrich ...................... to 49 days

Ostrich ......................... days

Ostrich ...................... days

Rheidae

Ostrich (In incubator) ...........42 days 6

Rhea Americana-Common Rhea........35 days 1

Rhea Americana-Nandu............39 days 9

Rhea Americana-Great-billed Rhea.......6 weeks 94

Rhea darwinii-Darwin's Rhea......30 to 31 days 13

Dromaeidae

Dromaeus novae-hollandiae-Emu.......56 days 1

Dromaeus novae-hollandiae-Emu. . about 8 weeks 10

Dromaeus novae-hollandiae-Emu......58 days 9

Dromaeus novae-hollandiae-Emu... about 8 weeks 14

Dromaeus novae-hollandiae-Emu (under hen) ........................ weeks 17

Dromaeus novae-hollandiae-Emu (Under normal parents of $\&$ ô $) . . . \ldots \ldots \ldots . .57$ days 17

Dromaeus novae-hollandiae--Emu (Under normal parents of only.............. (93) days 17

Emu ........................... days 15

Emu ......................58 days 94

Dromaeidae.........."the period being 80 days" 16

Dromaeidae .............. 70 to 80 days 25

Casuariidae

Casuarius bennetti-New Britain Cassowary-(Mooruk) ................42 days

*The author is confident that some of the incubation-length records included in this list are grossly incorrect, yet they are incorporated in the data, with a feeling that they will, in the future, be more accurately determined, and in that form recorded, and thus be corrected. 
Casuarius australis-Cassowary.........

.............. "probably 7 weeks or over" 14

Casuarius galeatus (?) - Cassowary......9 weeks 1

Cassowarie ..................... days 117

Crypturidae

Rhynchotus rufescens-Tinamou.......21 days 1

Aptervgidae

Apteryx australis-Kiwi.............6 weeks 1 Spheniscidae

Aptenodytes Fosteri-Emperor Penguin "some 7 or 8 weeks" 20

Emperor Penguin.................. weeks 138

Aptenodytes Pennanti-King Penguin...

.................... "said to be 7 weeks" 93

Pygoscelis Adaliae-Adele Penguin......37 days 20

Pygoscelis Adaliae- $\Lambda$ dele Penguin....

(more accurate) ................... days 20

Pygoscelis Adaliae-Adele Penguin.....31 days 20

Adelie Penguin.................33 to 36 days 133

Johnny Penguin...............33 to 37 days 134

Eudyptes Chrysocome-Tufted Penguin .................................. 6 weeks 14

Catarrhactes chrysocome-Crested Penguin ............................. 6 weeks 1

Sphenicus demersus-Black-footed Penguin $\ldots \ldots \ldots \ldots \ldots \ldots \ldots \ldots$ days 94

Gavidae

Gavia immer-Loon............. "about a month" 19

Gavia immer-Loon...............29 days 3

Colymbus arcticus-Black-throated Diver.28 days 1

Podicipedidae

Western Grebe.................21 days 18

Podicipes nigricollis-Eared Grebe.about 24 days 1

Podicipes Minor-Little Grebe.....20 or 21 days 1

Podicipes Cristatus-Great-crested Grebe

Podicipes novae-hollandiae--Black-

throated Grebe.................23 days 17

Podilymbus podiceps-Pied-bill Grebe...

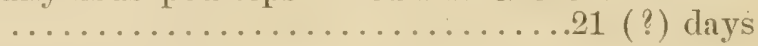

Diomedeidae

Diomedea exulans-Wandering Albatross "about 3 months" 14

Diomedea melanophrys-Black-eyebrowed

Albatross ...................60 days 1

Diomedea melanophrys-Black-eyebrowed

Albatross .................. "about 60 days" 14

Turbinares (?) ................... days 
Procellariidae

Fulmarus glacialis-Fulmar...... "about a month" 1

Fulmarus glacialis-Fulmar.......50 to 60 days 12

Puffinus tenuirostris-Short-tailed Petrel

(Mutton Bird) ...............56 days

Procellaria pelagica-Storm Petrel. .24 to 25 days

Procellaria pelagica-Uccello del tempeste 36 days

Storm Petrel (in incubator) ...........35 days

Ocennodroma lencorhoa-Leache's Petrel

Phaëthontidae

.30 (?) davs

Phaëthon americanus-Yellow-billed 'Tropic Bird ...................28 days

Yellow-billed Tropic Bird..... (at least) 28 days

Yellow-billed Tropic Bird (in incubator).28 days

Pelecanidae

Pelecanus ervthrorhynchos-White Pelican ....................29 to 30 davs

White Pelican ................29 days

Pelecanus onocrotalus-Pelikan.....36 to 38 davs 9

Pelecanus occidentalis-Brown Pelican...28 days :3

Pelican ............... "said to be 49 days" 28

Pelican (Sp?) ..................... k0 days 1

Phalacrocoracidae

Phalacrocorax carbo-Cormorant...28 to 29 days 1

Phalacrocorax carbo-Kormoran.......28 days 9

Phalacrocorax pelagicus pelagicus-Pelagic Cormorant (Est. by W.H.B.) ....26 days 21

Phalacrocorax urile-Red-faced Cormo-

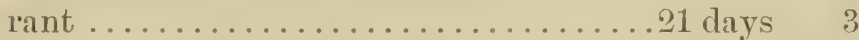

Phalacrocorax Sp.?-Cormorant.......28 days 28 Sulidae

Sula piscator-Red-legred Gannet.......45 days 14

Sula bassana-Gannet.............................. days 3

Sula bassana-Gannet..............39 days 1

Gannet (38 to 44 days) .......... . . . . . . . 42 days 28

Gannets ........................ (lays 25

Sula serrator-Australian Sula

........... "supposed to last only 33 days" 29

Gannet ................. "about 33 days" $1 t$

Ardeidae

Botaurus lentiginosus-Bittern........28 days :3

American Bittern............ (at least) 4 weeks 39

Ixobrychus exilis-Least Bittern........

...................... (estimated) 17 days

Botaurus stellaris-Bittern..........23 days

Ardetta Minuta-Little Bittern......16 or 17 days 
Ardea occidentalis-Great White Heron

Ardea herodias herodias-Great Blue

Heron .....................28 days 3

Great Blue Heron............. "about 28 days" 41

Ardea Cinerea-Fishreiher. .........25-28 days 9

Ardea Cinerea-Heron............25 to 26 days 1

Herodias garzetta-Seidenreiher.......23 days 9

Herodias timoriensis-Egret........about 4 weeks 14

Herodias timoriensis-TVhite Heron.....4 weeks 42

Ardea ludoviciana-Louisiana Heron...21 days 1

Butorides virescens virescens - Green

Heron ........................... days 3

Green Heron..................about 16 days 43

Nycticorax nycticorax naevius-Black-

crowned Night Heron..........24 (?) days 3

Nycticorax nycticorax-Nachtreiher....21 days 9

Circoniidae

Circonia Alba-Thite Stork.........23 days

Circonia circonia-Weisser Storch. .. 32 to 38 days

Ibididae

Ibis Aethiopica-Sacred Ibis..... about 21 days

Ibis molucca-Australische Ibis........24 days

Guara alba-Thite Ibis.............21 days

Guara alba-Thite Tbis..........20-23 days

Carphibis spinicollis-Stachelibis.......22 days

Plegadis falcinellus-Sichler. (Bay Ibis)

......................21-22 days

Plegadis autumnalis-Glossy Ibis.......21 days

Phoenicopteridae

Phoenicopterus ruber-Flamingo.......28 days

Phoenicopterus Sp.?-Flamingo.....30 to 32 days

Palamerleidae

Chauna chavaria - Tschajia (Derbian

Sereamer $)$....................42 days

Anatidae

Mergus americanus-American Merganser

........................ (at least) 28 days

Mergus americanus-Merganser........28 days

Mergus merganser-Goosander.........28 days

Mergus serrator-Red-breasted Merganser

Red-breasted Merganser (under hen)....

................................... 4 weeks" 32

Mergus serrator-Red-breasted Merganser

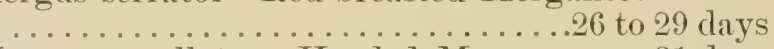

Mergus cucullatus-Hooded Merganser...31 days 
Fulvous Tree Duck................26-28 days 95

Tree Duck.....................26-28 days 95

Dendrocygna Fulva-Gelbe Baumente....32 days 162

Chenonette jubata-Hahnen Gans.....28-29 days 162

Casarca casarea-Rote Kasarka.........29 days 162

Anas platyrhynchos-Mallard......26 to 28 days 3

Mallard (varies from 23 to 29) ....27 to 28 days 95

Anas boseas-Wild Duck.............26 days 1

Ducks ......................28 days 25

Anas domesticus-Domestic Duck. .27 and 28 days 1

Duck .........................28 days 8

Duck-Common ..................28 days 33

Ducks ........................26 days 34

Duck-Common ...............24-29 days 9

Anas Rubripes-Black Duck. . . . . . . 26-28 days 3

Black Duck..................26-27 days 95

Anas angusterostris-Marbled Duck. 25 to 27 days 1

Barbary Duck.....................30 days 33

Gartwell ......................28 dlays 9.

Polionetta poecilorhyncha - Fleckenschnablente .................about 29 days 162

Chaulelasmus streperus-Schnatterente...

Anas superciliosa-Australische Wildente

.26 days 162

$.27-28$ days 162

Mareca Penelope-Widgeon........24 to 25 days

Mareca penelope-Pfeifente.........22-23 days

European Widgeon................... dayss

Querquedula crecca-Common Teal......22 days

Green-winged Teal.............21 to 23 days

Blue-winged Teal..............21 to 23 days

Cinnamon Teal...............21 to 23 days

Querquedula cyanoptera-Blauflügelente. .

.........................26 days 162

Querquedula circia-Gargoney .....21 or 22 days 1

Querquedula querquedula-Knakente.....

......................................... 24 days 162

Spatula clypeata - Shoveller.........28 days 1

Shoveller ....................22 to 24 days 95

Dafila acuta-Pintail...........22 or 23 days 1

Aix Sponsa-Wood Duck...........25 days 1

Wood Duck...................28-30 days 95

Lampronessa sponsa-Brantente........31 days 162

Aix galericulata-Mandarin Duck........30 days 95

Mandarin Duck...............28-30 days 1

Redhead .............................. 95

Nyroca ferruginea-White-eyed Duck... 
Nyroca nyroca-Moorente............28 days 162

Fuligula cristata-Tufted Duck....22 to 23 days 1

Fuligula fuligula-Rheierente......25 to 26 days 162

Metopiana peposaca-Peposacaente. 27 to 28 days 162

Netta rufina-Kolbenente...........28 days 162

Somateria mollissima-Eider Duck......28 days 1

Somateria mollissima borealis-Northern

Eider ..................... (?6) days

Somateria mollissima borealis-Northern

Eider ..................... 26 days

Somateria dresseri dresseri-American

Eider ....................25-26 days

Somateria spectabilis-King Eider. . ...25-26 days

Cereopsis novae-hollandiae - Cereopsis

Goose .............................. days

Cereopsis novae-hollandiae - Cereopsis

Goose ....................... about 30 days

Cereopsis novae-hollandiae-Hühnergans...30 days

Anser cinereus-Grey-lag Goose........28 days

Anser domesticus-Domestic Goose... . . . .30 days

Goose ............................30 days

Geese .............................. days

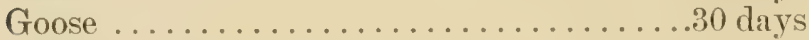

Geese .....................28-29 days

Anser brachyrhynchus-Pink-footed Goose 28 days

Anser arvensis-Acker Gans. . . . . . . . 28-29 days

Chen hyperboreus-Schneegans.......28-29 days

Branta canadensis canadensis-Canada

Goose ...................28 to 30 days

Bernicla canadensis-Canada Goose . 28 to 29 days

Canada Goose. . . . . . . . . . . . . . . . 17 days

Canada Goose..................28-30 days

Bernicla poliocephala - Ashey-headed

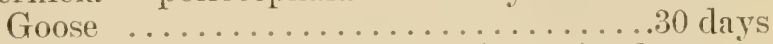

Bernicla sandvichensis-Sandwich Island

Goose ............................ days

Chloephaga magellanica-Magellangans..

........................28-29 days

Philacte canagica-Emperor Goose.....24 days

Chenalopex aegyptiaca-Egyptian Goose

Alopochen aegypticus-Nilgans, under

hen (domestic) .................28 days

Alopochen aegypticus-Nilgans, under

Muscovy Duck ................... 30 days

Tadorna cornuta-Shelldrake (common).30 days

Tadorna casarea-Ruddy Shelldrake....30 days

Pairina moschata-Turkenente.........35 days 
Olor cygnus-Whooping Swan.....35 to 40 days 3

Cygnus musicus-Whooper........................ days 1

Cygnus olor-Mute Swan.................... days 1

Cygnus olor-Swan.............35 to 42 days 36

Cygnus Melanocoryphus - Schwartzhals schwann ............................................ davs 162

Schwäne (Cygnus) ................................. 9

Swan ................................. 40 tays 25

Swan ..............between 5 and 6 weeks" 25

Swan .............................. days 8

Cygnus nigricollis-Black-necked Swan..35 days 1

Cygnus atratus-Black Swan..........35 days 1

Chenopis atrata-Schwartzer Schwann...35 days 162

Cathartidae

Sarcorhamphus gryphus-Kondor......55 days 9

Condor (in captivity) ................ days 2.5

Sarcorhamphus gryphus Condor.......54 days 2

Cathartes Californicus-California Vulture .................29 to 31 davs 1

Cathartes aura septentrionalis-Turkey Vulture ...............("close to") 30 days 192

Turkey Buzzard (Est. by W.H.B.) ..37 (?) days 55

Cathartes atrata-Black Vulture...28 to 30 days 35

Cathartes atrata-Black Vulture.......32 days 1

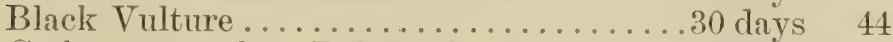

Cathartes urubu-Rabengeier.........40 days 9

Cathartes uruba-Black Vulture........30 days 3

Cathartes uruba-Black Vulture... about a month 100

Gypogeranidx

Serpentarius reptilivorus-Secretary Vulture ............................. 6 weeks

Falconidae

Prairie Falcon .............21 to 28 days

Falco peregrinus-Peregrine Falcon.18 to 19 days

Falco peregrinus anatum-Duck Hawk. 28 days

Duck Hawk .................... . 2s? days

Falco subbuteo-Hobby...........21 days

Falco columbarius columbarius-Pigeon

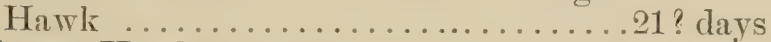

Pigeon Hawk ................... 1? days

Tinnunculus alaudarius-Kestrel .... .27-28 davs

Falco sparverius sparverius-sparrow

Hawk ................29 to 30 days

Sparrow Hawk ................21? days

Sparrow Hawk ..............29-30 days

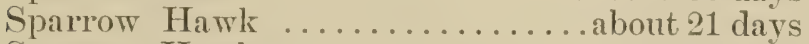

Sparrow Hawk ................29-30 days

Audubon's Caracara .............28? days 
Buteonidae

Pernis apivorus-Honey Buzzard......21 days 1

Cireus hudsonius-Marsh Hawk...26 to 28 days 3

Marsh Hawk.............. "is nearly 4 weeks" 57

Marsh Hawk ...................... days 43

Marsh Hawk .................21 days 44

Circus aeruginosus-Marsh Harrier.....

"21 to 24 days group" 1

Circus cyaneus............ "21 to 24 days group" 1

Accipiter velox-Sharp-shinned Hawk...21 days 3

Sharp-shinned Hawk ..............21 days 44

Accipiter cooperi-Cooper's Hawk.....24 days 3

Cooper's Hawk .................24 days 44

Accipiter nisus-Sparrow Hawk......21 days 1

American Goshawk ..............28? days 44

Harris Hawk ................28? days 44

Buteo borealis borealis-Red-tailed Hawk.28 days 3

Red-tailed Hawk ......................28 days . 44

Red-tailed Hawk .................32 days 194

Buteo borealis calurus-Western Red-

tailed Hawk...................28 days

Western Red-tailed Hawk...........28? days

Buteo lineatus-Red-shouldered Hawk...

........................ to 28 days

Red-shouldered Hawk ............28? days

Red-shouldered Hawk. ........ "less than 28 days"

Zone-tailed Hawk ................28? days

Buteo swainsoni-Swainson's Hawk. ..25-28 days

Swainson's Hawk ...............28? days

Swainson's Hawk .............about 25 days

Buteo platypterus-Broad-winged Hawk

..........................23-25 days

Broad-winged Hawk ............21-2t dars

Buteo vulgaris-Buzzard............21 days

Buteo vulgaris-Common Buzzard.......31 days

Urubitinga anthracina-Mexican Gos-

hawk (Black Hawk) ............24-28 days

Mexican Goshawk ..............21-28 days

Archibuteo lagopus sancti-johannis-

Rough-legged Hawk ..............28 days

American Rough-legged Hawk.......28? days

Archibuteo ferrugineus - Ferruginous

Rough-legged Hawk .............28 days

Ferruginous Rough-legged Hawk......28? days

Ferruginous Rough-legged Hawk. ..about 25 days

Milvus ictinus-Kite........"21 to 24 days group" 1

Pandion haliaëtus carolinensis-Osprey.27-28 days 3

Osprey ...................21-28 days 
Fish Hawk ....................28 days 65

Osprey ..................24-28? days 66

Aquila chrysaëtus-Golden Eagle.......30 days 1

Aquila chrysaëtos-Golden Eagle.......35 days 3

Golden Eagle ...................28 days 44

Golden Eagle 25-35 days (prob. avg.) ....30 days 60

Golden Eagle ..............."at least 32 days" 61

Golden Eagle ....................... days 63

Golden Eagle ...................... days 63

Aquila naevia-Spotted Eagle........21 days 1

Aquila imperialis-Imperial Eagle......35 days 1

Haliretus albicilla-Grey Sea Eagle.....30 days 3

Halixetus albicillis-Gray Sea Eagle..... "lasts about a month" 60

Haliæetus lencocephalus-Bald Eagle....30 days 3

Bald Eagle ...................28 days 44

Bald Eagle ......................... days 57

Bald Eagle ....................30-36 days 60

Bald Eagle (in captivity) . . . . . . . . . . 31 days 99

Nesaetus fasciatus-Bornelli's Eagle.....40 days 1

Vultur monachus--Mönchsgeier........51 days 9

Vulture monachus - Kuttengeier .........51 days 162

Gyps fulvus-Griffon Vulture........42 days 176

Gypaetus barbatus-Avvoltorio degli agnelli (Lämmergeier) .............20 days 12

Cercaëtus gallicus-Short-toed Eagle.... .

$$
\text { ............................... } 28 \text { days }
$$

Megapodidae

Lipoa ocellata-Malles Fowl. "from 38 to 41 days" 191

Lipoa ocellata-Mound Bird...........

...............takes a little over 5 weeks" 131

Lipoa ocellata rosinae-Malles Fowl.58 to 77 days 142

Megapodius duperreyi-Scrub Forvl....

.....................from 5 to 6 weeks 14

Megapodius duperreyi-Scrub Fowl.about 6 weeks 131

Catheturus lathami-Bush Turkey ... about 6 weeks 14

Catheturus lathami-Bush Turkey ... about 6 weeks 131

Cracidae

Crax globicera-Globose Currassow

(Probably 28) ...............28-31 days 169

Crax carunculata-Yarrell's Hokko... 28-29 days 162

Phasianidae

Colinus virginianus-Virginian Colin....

..................... "toward 4 weeks" 1

Colinus virginianus-Bobwhite .......24 days 3

Bobwhite Quail ..................24 days 44

Bobwhite ......................... days 45 
Bobwhite ...................24 days 35

Bobwhite (Quail) .............23 to 24 days 95

Plumed Quail ..................21 days 44

Scaled Quail ....................21 days 44

Callipepla californica-California Partridge .....................21 days 1

Lophortyx californica californica-California Quail .................24? days 3

California Quail ...............21-28 days 44

Lophortyx californica vallicola-Valley Quail .....................24? days

Valley Quail ...................28 days

Lophortyx californica gambeli-Gambel's

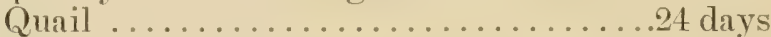
Gambel's Quail .................21-24 days

Caccabis rufa-Partridge (Red-Legged) .

......................23 \& 24 days Caceabis petrosa-Barbary Partridge 19 or 20 days Partridge $(S p$ ? ) ................24 days Perdix perdix-Hungarian Partridge....

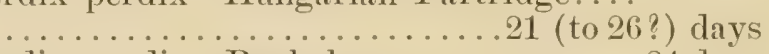

Perdix perdix-Rephahn...........24 days

Perdix Cinerea-Partridge..........25 days

Coturnix communis-Quail..........21 days

Synoecus ąustralis-Brown Quail, under hen ............................ days

Coturnix novae-zealandiae-New Zealand Quail .......................21 days

Coturnix novae-zealandiae-New Zealand Quail ......................21 days

Tetrao tetrix-Black Grouse..........26 days

Tetrao urogallus-Capercaillie........26 days

Dusky Grouse ................18-24 days

Dendragapus obscurus obscurus-Dusky Grouse ...................24 days Sooty Grouse .................18-24 days

Dendragapus obscurus fuliginosus-Sooty Grouse ...................24 days Canchites canadensis canace - Spruce Grouse .......................17 days 180 Bonasa umbellus-Ruffed Grouse.......21 days 1 Bonasa umbellus umbellus-Ruffed Grouse 21 days 3 Canada Ruffed Grouse................17 days 35 Ruffed Grouse ..................24-28 days 44 Ruffed Grouse ...................24 days 95 Bonasa umbellus togata-Canadian Ruffed Grouse .......................21 days Canada Grouse .................... days 
Canada Grouse ................24-28? days 44

Bonasa betulina-Hazel Grouse........21 days 1

Lagopus lagopus lagopus-Willow Ptarmigan .......................... days 3

Lagopus lagopus-Schnee Huhn.......26 days 9

Lagopus lagopus-Schnee Huhn.......26 days 162

Willow Ptarmigan.................. 17 days 44

Lagopus rupestris-Rock Ptarmigan.....24 days 1

Lagopus scoticus-Red Grouse.........24 days 1

Lagopus albus-Willow Ptarmigan......24 days 1

Tympanuchus americanus americanus-

Prairie Chicken .................21 days 3

Prairie Hen .................21-28 days 44

Heath Hen ..................24 days 47

Cupidonia cupido-Prairie Hen.....18 or 19 days 1

Columbian Sharp-tail Grouse.........21 days 44

Pediaecetes phasianellus columbianus-

Columbian Sharp-tail Grouse........21 days 3

Prairie Sharp-tail Grouse.............21 days 44

Pediaecetes phasianellus campestrisPrairie Sharp-tail Grouse..........21 days 3

Centrocercus urophasianus-Sage Grouse..22 days 3

Tetrao urophasianus-Sage Grouse....21-22 days 1

Sage Hen ....................21 days 44

Sage Hen ................... "about 3 weeks" 48

Meleagris gallopavo silvestris-Wild Tur-

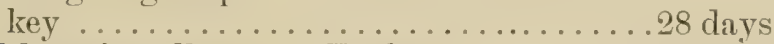

Meleagris gallopavo-Turkey .......26-28 days

Wild Turkey ..................28 days

Mexican Wild Turkey..............28 days

Meleagris gallo-pavo-Domestic Turkey...28 days

Meleagris americana-Domestic Turkey. .

"four" weeks of incubation" 49

Turkey ......................28 days 8

Turkey .....................28 days 33

Numida meleagris - Guinea Fowl......25 days 1

Numida meleagris-Guinea Fowl......28? days 51

Guinea ........................... days 33

Guinea Hen ...................28 days 8

Ceriornis satyra - Horned Tragopan (Horned Pheasant)...............28 days 1

Ceriornis temmincki-Temminck's Tragopan .......................... days 1

Lophophornis impeyanus - Himalayan Monal ......................28 days 1

Crossoptilon mantchuricum-Mantchurian Crossoptilon ..............28 or 30 days 
Family-Species

Period Authority

Euplocamus albi-cristatus-White-crested

Kaleege ...................26 days 1

Euplocamus nycthemerus-Silver Pheas-

ant $\ldots \ldots \ldots \ldots \ldots . \ldots . . .26$ days 1

Euplocamus nycthemerus-Silver Pheasant (under hen) ..............26 days 108

Euplocamus melanotus - Black-backed

Kaleege ..................24 days 1

Euplocamus Horsfieldi-Purple Kaleege..24 days 1

Gennaeus, species of..........24-25 days 97

Gennaeus nvethemerus............26 days 162

Gennaeus lineatus...............26 davs 162

Gennaeus melanotus..............26 days 162

Gennaeus albocristatus............26 days 162

Phasianus colchicus-Common Pheasant. .23 days 1

Phasianus colchicus-English Pheasant 23-24 days 3

Phasianus mongolicus............24-25 days 162

Phasianus versicolor............26 days 162

Phasianus torquatus..............26 days 162

Phasianus principalis-Prince of Wales

Pheasant.................... 2t davs 108

Phasianus reevesi-Reeves's Pheasant....24 days 108

Syrmaticus reevesii.............24-25 days 162

Syrmaticus reevesii-Reeves's.........24 days 108

Pheasant (sp.?) .................................. 33

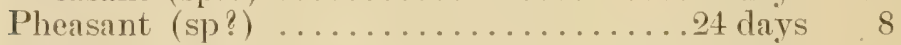

Pheasant (sp.?) .............23-2t days 25

Pheasant (sp.?) ................24 days 50

Pheasant Ring-neck ..............24 days 108

Syrmaticus wallichi-Cheer Pheasant....28 days 1

Calophasis mikado-Mikado ..........28 days 68

Calophasis ellioti ..............24-25 days 162

Thaumalea picta-Golden Pheasant.....22 days 1

Golden Pheasant ...............21 days 108

Chrysolophus pictus-Golden Pheasant.21-22 days 97

Chrysolophus pictus-Gold Fasan....23-24 days 162

Chrysolophus amherstiae-Iady Amherst

Pheasant ...............22-23 days

Chrysolophus amherstiae-Amherst Fasan

.....................23-24 days 162

Gallus various-Forked-tail Jungle Fowl..21 days 1

Gallus domesticus-Hen (Dorking var.) . .

.....................20-21 days

Hen .......................21 days

Hen .......................21 days

Gallus domesticus-Bantam.........21 days

Polyplectron chinquis-Peacock Pheasant 21 days

Polyplectron chinquis-Peacock Pheasant 21 days

Argus giganteus-Argus Pheasant......24 days 
Family-Species

Period Authority

Argusianus argus-Argus..........26 days 9

Pavo cristatus-Peafowl............28 days 1

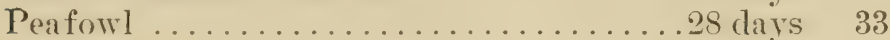

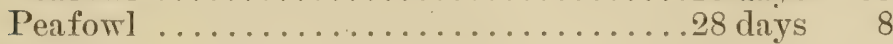

Rallidae

Rallus Crepitans-Clapper Rail........14 days 1

Porzana carolina-Sora Rail.........14? days 3

Porzana maruetta-Spotted Crake......21 days 1

Porzana parvia-Little Crake.......21-24 days 1

Crex pratensis-Corn Crake.......21-24 days 1

Gallinula chloropus-Moor Hen.......21 days 1

Porphyrio caeruleus-Purple Gallinule.23-25 days 130

Ocydromus australis-Weka Ralle.....28 days 9

Eulabeornis Ypacha-Ypakaha Ralle...21 days 9

Fulica atra-Coot (European).......22 days 1

Gruidae

Fulica americana-Coot.............14 days 3

Grus communis-Crane...........28 days 1

Grus japonensis-Mandschurischae Kranich $\ldots \ldots \ldots \ldots \ldots \ldots \ldots \ldots \ldots \ldots \ldots \ldots \ldots$ days 9

Grus viridirostris-Mantchurian Crane...30 days 1

Grus canadensis-Kanadische Kranich...33 days 162

Anthropides paradisea-Paradieskranich

......................34-35 days 9

Anthropides virgo-Jungfernkranich....28 days 9

Cariamidae

Cariama Cristata-Seriema ........28 days 9

Otididae

Otis Tarda-Great Bustard....... "about 4 weeks" 1

Rhinochetidae

Rhinochetus jubatus-Kagu (in incuba-

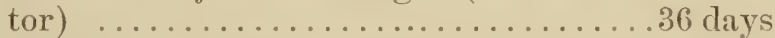

Rhinochetus jubatus-Cagon (in captiv-

ity) ....................... days

Eurypygidae

Eurypyga helias-Sun Bittern.......27 days Charadriidae

Recurivrostra avocetta-Avocet......17-28 days

Scolopax rusticula-Woodcock........20 days

Philohela minor-Woodcock........20-21 days

Gallinago major-Great Snipe......16 to 18 days

Gallinago caelestis-Common Snipe.....20 days

Tringa alpina-Dunlin.............22 days

Totanus hypoleucus-Common Sandpiper

.......................22 days

Totanus calidris-Redshank......14 to 16 days

Totanus calidris-Redshank..........23 days

Totanus calidris-Pettigola..........23 days

8

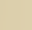

(n)

(1)

(1)

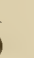

9

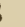

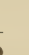

(1)

(1)


Totanus ochropus-Green Sandpiper.21 to 24 days 1

Machetes pugnax-Ruff.............16 days 1

Bartramia longicauda-Bartram's Sandpiper ................... days 3

Actitis mascularius-Spotted Sandpiper

$\ldots \ldots \ldots \ldots \ldots \ldots \ldots \ldots \ldots \ldots$. $\ldots \ldots \ldots$ days 3

Numenius arquata-Curlew ..........30 days 1

Haematopus vulgaris-Lapwing....25 to 26 days 1

Eudromias morinellus-Dotterel.....18 or 20 days 1

Zonifer tricolor-Brust-Schild Kubitz...28 days 162

Charadrius pluvialis-Golden Plover....27 days 1

Aegialitis hiaticula-Ringed Plover......

Aegialitis vociferus-Killdeer (about)...26 days

Oxyechus vociferus-Killdeer (probably $261 / 2-271 / 2) \ldots \ldots \ldots . . .28$ clays

Haematopus palliatus-Oystercatcher...14? days

Recurvirostra ostralegus-Oystercatcher..

$$
.23 \text { to } 24 \text { days }
$$

(1)

(1)

1

Oedicnemidae

Oedicnemus scolopax-Stone Curlew 16 or 17 days 1

Laridae

Stercorarius catarrhactes-Great Skua

about 4 weeks

Megalestris maccormicki-Skua Gull....4 weeks

Rissa tridactyla-Kittiwake........26 days

Larus glaucus-Glaucus Gull.........28 days

Larus Marinus-Mantel Möwe..........26 days

Larus argentatus-Herring Gull.......26 days

Larus argentatus-Herring Gull. . . .26 or 27 days

Herring Gull ............... one set 24 days

Herring Gull .............two sets 25 days

Herring Gull ............ five sets 26 days

Herring Gull ............. four sets 27 days

Herring Gull .............. three sets 28 days

Larus ridibundus-Black-headed Gull...

.................22 and 23 days

Larus franklini-Franklin's Gull...18 or 20 days

Franklin's Gull .............18 or 20 days

Sterna caspia-Caspian Tern.......about 20 days

Sterna Fluviatilis-Common Tern......

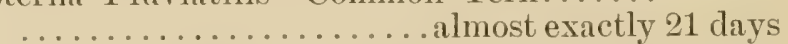

Sterna Fluviatilis-Common Tern...22 \& 23 days

Sterna hirundo-Common Tern.......21 days

Sterna hirundo-Rondine di Mare....21-23 days

Sterna arctica-Arctic Tern.......15 or 16 days

Sterna dougalli-Roseate Tern.........21 days

Sterna minuta-Little Tern........14 to 16 days 
Sterna fuscata-Sooty Tern........26-29 days 3

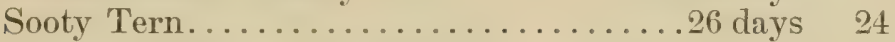

Sterna fuliginosa-Sooty Tern.....15 or 16 days 14

Hydrochelidon niger surinamensis-Black

Tern .................. 17 to 19 ? days 187

Hydrochelidon niger-Black Tern...15 or 16 days 1

Noddy Tern .................................... days 24

Anous stolidus-Noddy ..........35-36 days 3

Anous stolidus-Noddy Tern.......35-36 days 106

Alcidae

Fratercula arctica-Puffin............36 days 1

Fratercula corniculata-Horned Puffin

(Est. by W.H.B.) ............25-32 days

Cepphus grylle-Black Guillemot......21 davs

Uria grylle-Black Guillemot.........24 days

Lomvia troile-Guillemot................ 30 . 33 days

Alca torda-Razor-bill .............30 days

Pteroclidae

Pterochurus alchata-Pin-tailed Sand

Grouse ................."about 25 days" 1

Syrrhaptes paradoxus-Pallas's Sand

Grouse ..................28 days 1

Columbidae

Columba fasciata fasciata-Band-tailed

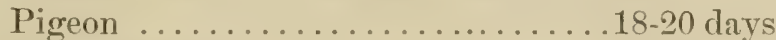

Band-tailed Pigeon ............. 18-20 days

Red-billed Pigeon................18-20 davs

Columba livia-Rock Dove.........16 to 18 days

Columba livia-Domestic Dove........14 days

Columba livida-Tauben ..........17-18 days

Pigeon ....................... 18 days

Pigeon............... (almost exactly) 17 days

Columba domestica-Rock Dove..." about 2 weeks" 52

Columba aenas-Stock Dove.......17 to 18 days 1

Columba palumbus-Ring Dove.........17 days 1

Ectopistes migratorius-Passenger Pigeon

Ectopistes migratorius-Passenger Pigeon

$$
16 \text { days } 1
$$

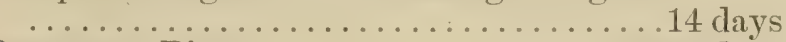

Passenger Pigeon .............. 18-20 days

Passenger Pigeon.... ("almost to a day") 14 days 53

Zenaidura macroura carolinensis-Mourning Dove ...................12-14 days 3

Mourning Dove ..................... 92

Mourning Dove ..................... days 44

Mourning Dove .................... days 97

Melopelia asiatica-White-winged Dove. 
White-winged Dove ................18 days 44

Turtur risorius-Collared Turtle Dove...15 days 1

Turtur risorius-Ring Dove.......about 15 days 92

Turtur communis-'Turtle Dove.....16 to 17 days 1

Chaemepelia passerina terrestris-Ground

Dove ............................. davs 3

Ground Dove ......................14 days 44

Mexican Ground Dove..............14 days 44

Ocyphaps lophotes-Crested Pigeon.....14 days 1

Ocyphaps lophotes-Crested Dove..about 14 days 97

Caloenas nicobarica-Nicobar Pigeon....28 days 1

Goura coronata-Crowned Pigeon......28 days 1

Crowned Pigeons (Gouridae).........28 days 116

Cuculidae

Geococcyx californicus-Roadrunner.....18 days 3

Coccrzus americanus americanus-Yellow

billed Cuckoo....................14 days

Coccyzus americanus americanus-Yellow-

billed Cuckoo.................. about 14 days

Coccyzus erythropthalmus - Black-billed

Cuckoo .......................... days

Cuculus canorus-Kuckuck. . . . ........11 days

Cuculus canorus-Cuckoo..........13 to 14 days

Cuculus pallidus-Pallid

Cuckoo .................. about 12 or 14 days

Chalcococcyx lucidus-Broad-billed Bronze

Cockoo .......................... days

Trichoglossidae

Trichoglossus novae-hollandiae -Swain-

son's Lorikeet..................21 days

Psittacidae

Cacatua cristata-Great White-crested

Cockatoo ...................21 days

Cacatua goffini-Goffin's Cockatoo......21 days

Cacatua rosicapilla-Roseate

Cockatoo ................ "about 21 days" 1

Colopsitta novae-hollandiae-

Cockateel ..............."about 20 days"

Licmetis nasica-Long-billed

Cockatoo ................."about a month"

Licmetis tenuirostris-Slender-billed

Cockatoo ................"about 21 days"

Cyanorhamphus novae-zealandiae-New

Zealand Parrakeet ........... "about 18 days"

Ara ararauna-Blie and Yellow

Macaw ..................20-25 days 
Melopsittacus undulatus-Warbling Grass

Parrakeet .............. "about 20 days" 14

Melopsittacus undulatus-Waved Parrakeet ....................16 to 20 days 1

Neophema (?) venusta-Blue-winged Grass Parrakeet ............... 19-22 days 14

Euphema bourkei-Bourke's Parrakeet ................... "about 17 days" 1

Euphema Pulchella-Torquoisine Parrakeet ................... "about 18 days" 1

Euphema splendida-Splendid Grass Parrakeet ..............."about 18 days" 1

Parrots-period of incubation is

................... approximately 21 days

Psephotus haematonotus-Blood-rumped Parrakeet ............................. 17 days 1

Lathamus discolor-Swift Parrakeet.....21 days 1

Carolina Parrakeet (in captivity) . . . . .21 days 98

Parrots-Small .................. 16-20 days 162

Parrots-Large ..................25-30 days 162

Coraciidae

Coracias garrulus-Roller ........18 to 20 days 1

Alcedinidae

Ceryle alcyon-Belted Kingfisher........16 days 1

Ceryle alcyon-Belted Kingfisher......23-24 days 3

Alcedo insipida-Kingfisher ............14 days 1

Halcyon vagans-New Zealand Kingfisher ......................... days

Halcyon vagans-New Zealand Kingfisher ....................... 19 days 1

Halycon sanctus-Sacred King-

fisher .............................. 17 days

Upupidae

Upupa epops-Hoopoe ..............16 days 1

Strigidae

Aluco pratincola-Barn Owl........21-24 days

Barn Owl .......................... days

Barn Owl ......................... to $31 / 2$ weeks 57

Asio otus-Long-eared Owl...........27 days 1

Asio wilsonianus-Long-eared Owl.....21 days 3

American Long-eared Owl...........21? days 44

Long-eared Owl ............... "about 3 weeks" 30

Long-eared Owl .............. "about 21 days" 35

Long-eared Owl .............. "about 3 weeks" 57

-Asio flammens-Short-eared Owl.......21 days 3

Short-eared Owl ...............21? days 44 
Scleoglaux albifacies-Laughing Owl...25 days 42 Barred Owl .................21-28 davs 44

Syrnium aluco-Tawney Owl........21 days 1

Cryptoglaux arcadia arcadia-Saw-whet

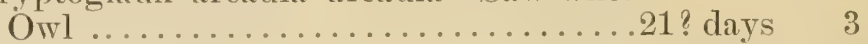

Saw-whet Owl ..................... days 44

Otus asio asio-Screech Owl......21-26 days 3

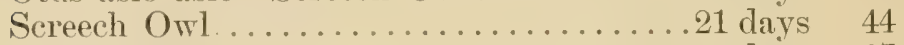

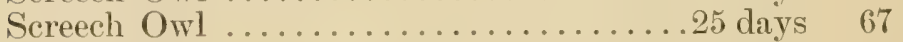

Screech Owl .................22 days 57

Macfarland's Screech Owl.........21-28? days 44

Bubo virginianus virginianus-Great-horned Owl ....................28-30 days Great-horned Owl......."probably about 4 weeks" Great-horned Owl..............21-28 days Bubo virginianius pallescens-Western Horned $\mathrm{O} w 1 . . . . . . . . . . .28$ days

Western Great-horned Owl..........28? days Bubo virginianius pacificus-Pacific Horned Owl .......................28 days

Bubo turcomanus-Turkman Uhu.....27-33 days

Bubo Ignavus-Eagle Owl........21 to 24 days Nyctea scandiaca-Snowy $\mathrm{O} w 1 . . . . . .32$ days Speotyto cunicularia hypogaa-Burrowing Owl ....................21-28 days Burrowing Owl ................21? days Athene noctua-Little $\mathrm{Owl}$-........14 to 16 days Micropallas whitneyi-Elf $\mathrm{Owl} \ldots . . \ldots 14$ days

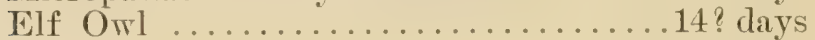

Caprimulgidae

Antrostomus vociferus-Whip-poor-will...17 days

Chordeiles virginianus-Nighthawk.16 to 18 days

Chordeiles virginianus-Nighthawk. "a fortnight"

Caprimulgus europaeus-Nightjar.......15 days

Trochilidae

Trochilus colubris-Ruby-throated Hummingbird ..................... days

Trochilus colubris-Ruby-throated Hummingbird ....................... days

Trochilus colubris-Ruby-throated Hum-

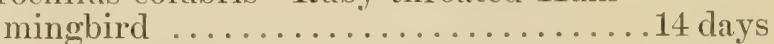

Trochilus colubris-Ruby-throated Hum-

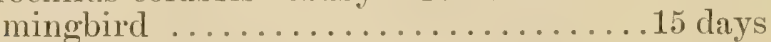
Archilochus colubris-Ruby-throated, Hummingbird ................. 14 days Archilochus alexandri-Black-chinned Hummingbird 13 days 
Calypte costae-Costa's Hummingbird....14 days 3

Calypte anna-Anna's Hummingbird....14 days 3

Selasphorus rufus-Rufous Hummingbird.12 days 3

Florisuga atra-Black Hummingbird....12 days 1

Hummingbirds ............12-14-18 days 71

Micropodidae

Cypselus apus-Swift..........16 or 17 days 1

Cypselus melba-Alpine Swift

.................. "a little over 2 meeks" 1

Chretura pelagica-Chimney Swift.....18 days 3

Chretura pelagica-Chimney Swift......19 days $18 t$

Chimney Swift .............22 days 194

Trogonidae

Hapaloderma narina-Narina Trogon....20 days 1

Picidae

Gecinus viridis-Green Woodpecker.. 16 to 18 days 1

Dendrocopus major-Great Spotted

Woodpecker ................14 to 16 days 1

Dendrocopus medius-Middle Spotted

Woodpecker............................. days 1

Dendrocorpus minor-Lesser Spotted

Woodpecker ................... 14tays 1

Dryobates villosus villosus-Hairy

Woodpecker ................... days ?

Dryobates villosus hyloscopus-Cabanis'

Woodpecker ...................... days ?

Dryobates pubescens medianus-Downy

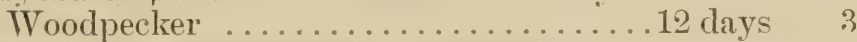

Dryobates scalaris bairdi-Texas IVoodpecker .......................... days 3

Xenopicus albolarvatus-White-headed

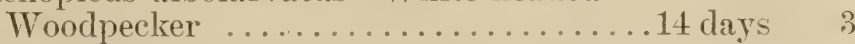

Picoides americanus americanus-Three-

toed Woodpecker .................. days 3

Sphyrapicus varius nuchalis-Red-naped

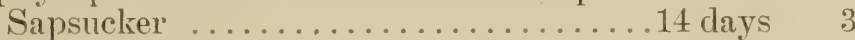

Sphyrapicus ruber ruber-Red-breasted Sapsucker ................12-14 days 3

Phlaeotomus pileatus pileatus-Pileated Woodpecker ........................ days 3

Picus martius-Great Black Woodpecker ..................... to to 18 days 1

Melanerpes erythrocephalus-Red-headed

Woodpecker ..................14 days 3

Asyndesmus lewisi-Lewis's Woodpecker..14 days 3

Centurus carolinus-Red-bellied Wood-

pecker ....................14 days 
Centurus aurifrons-Golden-fronted Woodpecker .......................14 days

Centurus uropygilais-Gila Woodpecker..14 days

Colaptes auratus luteus-Flicker......11-14 days

Flicker ..................... 11-12 days

Flicker ................... "about 16 days"

Iynx torquilla-Wryneck .............14 days Tyrannidae

Muscivora forficata-Scissor-tailed Fly-

catcher ....................12-13 days

Tyrannus tyrannus-Kingbird........12-13 days

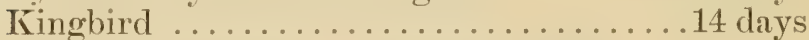

Tyrannus verticalis-Arkansas Kingbird ......................12-13 days

Tyrannus verticalis-Arkansas Kingbird. .14 days

Tyrannus vociferans-Cassin's Kingbird .......................12 days

Myiarchus crinitus-Crested Flycatcher ......................13-15 days

Myiarchus cinerascens cinerascens-Ash-

throated Flycatcher ...............15 days

Sayornis phoebe-Phoebe..........12-14 days

Phoebe .......................15 days

Phoebe ....................15-16 days

Sayornis sayus-Say's Phoebe..........12 days

Say's Phoebe....................... days

Nuttalornis borealis-Olive-sided Flycatcher ........................ days

Myiochanes virens-Wood Pewee.....12-13 days

Empidonax difficilis difficilis-Western

Flycatcher ........................ days 3

Empidonax trailli trailli-Traill's Flycatcher .....................12 days

Empidonax trailli alnorum-Alder Flycatcher ......................12 days

Empidonax minimus-Least Flycatcher...12 days

Least Flycatcher ..................14 days

Empidonax wrighti-Wright's Fly-

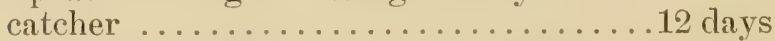

Pyrocephalus rubinus mexicanus-Vermilion Flycatcher................12 days

\section{Menuridae}

Menura superba-Lyre Bird ("sometimes extends over a month") .............31 days Lyre Bird ................. "about a month"

Menura victorae - Victoria Lyre Bird 
Alaudidae

Otocoris alpestris leucolaema-Horned

Lark .......................11-14 days 146

Alauda arvensis-Sky Lark............14 days 1

Alauda arvensis-Lodola...........13-14 days 12

Alauda arvensis-Skylark ..........13-14 days 2

Alauda arborea-Wood Lark...... about 15 days 1

Alanda cristata-Crested Lark

.................. "about a fortnight"

Motacillidae

Motacilla alba-White Wagtail.........14 days

Motacilla alba-Ballerina ............14 days

Motacilla lugubris-Pied Wagtail........13 days

Motacilla lugubris-Pied TVagtail

"middle of the 14th day"

Anthus pratensis-Meadow Pipit...13 and 14 days

Anthus trivialis-Tree Pipit...........13 days

Pycnonotidae

Pycnonotus leucotis-Weissorbulbul.....11 days 162 Muscicapidae

Muscicapa grisola-Spotted Flycatcher...13 days 1

Muscicapa atricapilla-Pied Flycatcher...14 days 1

Rhipidura tricolor-Black and White

Fantail ....................... days

Rhipidura albiscapa-White-shafted

Fantail .....................16 days 14

Rhipidura albiscapa-White-shafted

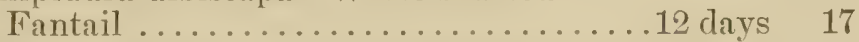

Melurus superbus - Superb Warbler.about 14 days 17

Melurus cyaneus-Blue Wren..........14 days 14

Gerygone albigularis-White-throated

Bush Warbler................"about 12 days" 17

Melanodryas petroeca (?)-Hooded

Robin ......................16-17 days

Turdidae

Hylocichla mustelina-Wood Thrush.....14 days

Wood Thrush ......................12 days

Hylocichla ustulata ustulata-Russet-backed

Thrush ....................... days 14

Hylocichla ustulata swainsoni-Olive-backed

Thrush .................10-13 days 3

Hylocichla guttata pallasi-Hermit

Thrush .......................12 days

Hermit Thrush ................. 12 days

Turdus musicus-Song Thrush.........15 days

Turdus viscivorus-Missle Thrush.......15 days

Turdus merula-Blackbird .......14 and 15 days 
Turdus merula-Blackbird ...........15 days 2

Merula merula-Merlo ............15 days 12

Planesticus migratorius migratorius-

Robin ....................11-14 days

Robin (Eastern) .............exactly 14 days

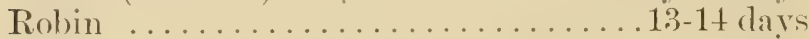

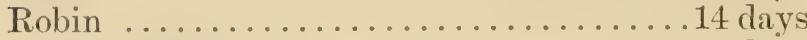

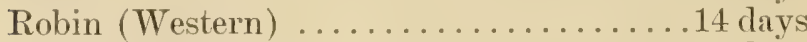

Robin (Western) .............exactly 14 days

Accentor modularis-Hedge Sparrow .... 14 days

Ruticilla phoenicurus-Redstart.........13 days

Ruticilla phoenicurus-Redstart ....... 14th day

Ruticilla phoenicurus-Codirosso........14 days

Ruticilla titys-Black Redstart..........13 days

Erithacus rubecula-Redbreast..........14 days

Erithacus rubecula-Pettirosso .......13-15 days

Erithacus rubecula-Redbreast .......13-14 days

Daulias luscinia - Nightingale......"a fortnight"

Sialia sialis sialis-Bluebird... . . . . . . 12 days

Sialia sialis sialis-Bluebird.........14-15 days

Mimidae

Mimus polyglottos polyglottos-Mocking-

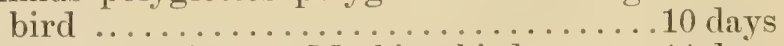

Mimus polyglottos-Mocking-bird.... . . . 14 days

Dumetella carolinensis-Catbird...... 12-13 days

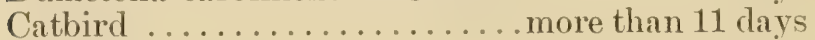

Toxostoma rufum-Brown Thrasher... 13-14 days

Brown Thrasher ...............12? days

Toxostoma curvirostre curvirostre-Curvedbilled Thrasher .................13 days

Cinclidae

Cinclus aquaticus-Dipper ...........15 days

Troglodytidae

Thryothorus ludovicianus ludoricianus-

Carolina Wren ...................12 days

Thryothorus ludovicianus miamensis-

Florida Wren ...................14 days

Thryomanes bewicki-Bewick's Wren. 10-15 days

Troglodytes aëdon aëdon-House Wren 11-13 days Troglodytes parvulus-Wren...........13 days

Anorthura troglodytes-Scricciolo.......10 days

Telmatodytes palustris palustris-Long-

billed Marsh Wren.............10-13 days

Chamaeidae

Chamoea fasciata fasciata-Wren Tit..15-18 days 
Acrocephalus palustris-Marsh Warbler...13 days 1

Acrocephalus turdoides-Great Reed

Warbler ...................14-15 days 1

Acrocephalus phragmitis-Sage Warbler..15 days 2

Sylvia curruca-Lesser Whitethroat....12-14 days 1

Sylvia cinerea-Whitethroat . . . . . . 11-13 days 1

Sylvia atricapilla-Blackcap..........14 days 1

Sylvia hortensis-Garden Warbler.......15 days 1

Sylvia sylvia-Sterpazzola ..........10 days 12

Phylloscopus trochilus-Willow Wren...13 days 1

Phylloscopus rufus-Chiffchaff .......13 days 1

Sericornis frontalis-White-browed

Scrub Wren ................21-23? days

Prinia maculosa-Capocier...........14 days

Geobasileus reguloides-Buff-rumped

Thornbill ................ "about 12 days"

Regulidae

Regulus cristatus-Goldcrest.........12 days 1

Hirundinidae

Progne subis subis-Purple Martin....12 15 days

Martin .....................12-15 days

Pertocheildon lunifrons lunifrons-Cliff

Swallow ..................12-14 days

Hirundo erythrogastra-Barn Swallow...11 days

Hirundo erythrogastra-Barn Swallow. . 13 days

Hirundo rustica-Swallow. . . . . . . . . 15 days

Hirundo rustica-Swallow

Hirundo rustica-Rondine............15 days

Hirundo neoxena-Welcome Swallow. . . . 14 days

Iridoprocne bicolor-Tree Swallow . . . . . . 14 days

Chelidon urbica-Martin.............13 days

Cotile riparia-Sand Martin.......12 or 13 days Ampelidae (or Bombycillidae)

Bombycilla cedrorum-Cedar Waxwing ..................... 10 days

Cedar Waxwing ........... (probably) 14 days

Bombycilla cedrorum-Cedar Waxwing. .16 days Ptilogonatidae

Phainopepla nitens-Phainopepla .......16 days Artamidae

Artamus superciliosus-Wood

Swallow ........................... 14 days

Laniidae

Lanius ludovicianus ludovicianus-

Loggerhead Shrike ............12-13 days 
Lanius ludovicianus migrans-Migrant Shrike ...................13-16 days 3

Lanius excubitor-Great Grey Shrike .15 to 16 days

Lanius minor-Lesser Grey

Shrike ...................15 to 16 days

Lanius collurio-Red-backed Shrike......14 days

Lanius pomeranus-Woodchat ........15 days

Falcunculus frontatus-Shrike Tit. . . 18-20 days Vireonidae

Vireosylva olivacea-Red-eyed Vireo...12-14 days

Vireo gilvus-Warbling Vireo..........12 days

Lanivireo solitarius solitarius-Blue-headed

Vireo .......................10-11 days

White-eyed Vireo ................ ? ? days

White-eyed Vireo ................... days

Sittidae

Sitta caesia-Nuthatch ............13-14 days 1

Sitta canadensis-Red-breasted Nuthatch..12 days 3 Paridae

Panthestes atricapillus atricapillus-

Chickadee ..................11-14 davs

Parus major-Great Tit...... "end of 14th day"

Parus caeruleus-Blue Titmouse.........14 days

Parus palustris-Marsh Titmouse. "about 13 days"

Parus ater-Coal Titmouse............14 days

Acredula rosea-Long-tailed Titmouse..11-13 days

Panurus biarmicus-Bearded Titmouse...14 days

Oriolidae

Oriolus galbula-Golden Oriole.........15 days 1

Corvidae

Pica rustica-Magpie................18 days 1

Pica pica hudsonia-Magpie.........16-18 days 3

Magpie ............ between 15 and 20 days" 4i

Cyanopolius cyanus-Chinese Blue

Magpie .................."about 18 days"

Garrulus glandarius-Jay.............16 days

Cyanocitta cristata cristata-Blue Jay.. 15-17 days

Cyanocitta cristata cristata-Blue Jay ....17 days

Cyanocitta stelleri stelleri-Steller's Jay.. 16 days

Cyanocitta stelleri frontalis-Blue-fronted Jay ........................ days

Aphelocoma woodhousei-Woodhouse's

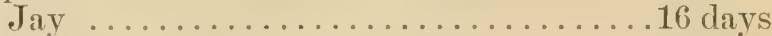

Aphelocoma californica-California Jay.. 16 days

Aphelocoma sieberi arizonae-Arizona Jay ........................... days 
Perisoreus canadensis canadensis-Canada

$$
\text { Jay ....................... 16 days }
$$

Canada Jay .......................... days

Corvus corax-Raven...........18 to 19 days

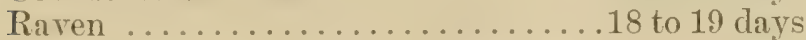

Corvus corax principalis-Northern

Raven ...................20-21 days

Corvus cryptoleucus-IVhite-necked

Raven .....................21 days

Corvus brachyrhynchos-Crow.........18 days

Corvus ossifragus-Fish Crow........16-18 days

Corvus frugilegus-Rook........17 and 18 days

Corvus cornix-Hooded Crow......18 to 20 days

Corvus corone-Carrion Crow.......18 to 20 days

Nicifraga caryocatactes-Nutcracker. . 17-18 days

Nicifraga columbiana-Clark's Nutcracker ....................16-17 days

Nicifraga columbiana-Clarke's Nutcracker ...................22 days

Cyanocephalus cyanocephalus-Pinon Jay ............................. days

Sturnidae

Sturnus vulgaris-Starling...........14 days

Sturnus vulgaris-Starling.........11-14 days

Temenuchus pogadarum. . . . . . . . . 14-16 days

Poliopsar malabaricus. . . . . . . . . . 14-16 days

Poliopsar andarrensis.............14-16 days

Meliphagidae

Ptilotis notata-Yellow-spotted Honey

Eater ........................ 14 days

Ptilotis notata-Yellow-spot Honey Eater. 14 days

Zosteropidae

Zosterops coerulescens - White Eye. about 10 days

Zosterops coerulescens-Silver Eye....9 to 10 days

Zosterops palpebrosa-Thite Eyes.....10-11 days

Certhiidae

Certhia familiaris-Brown Creeper...12-13? days

Certhia familiaris-Tree Creeper........15 days Mniotiltidae

Protonotaria citrea-Prothonotary

Warbler ....................14 days

Helmintheros vermivorus-Worm-eating

Warbler ....................13 days

Vermivora pinus-Blue winged Warbler. 10 days

Blue-winged Warbler..................10 days

Blue-winger Warbler ..............10-14 days

Vermivora chrysoptera-Golden-winged

Warbler 
Vermivora rubicapillus rubicapillus-

Nashville Warbler ...............11-12 days

Dendroica aestiva aestiva-Yellow

Warbler .....................10-11 days

Yellow Warbler ..................... days

Yellow Warbler ....................11 days

Dendroica coronata-Myrtle Warbler..12-13 days

Dendroica magnolia-Magnolia Warbler..12 days

Magnolia Warbler ..............12-13? days

Dendroica pensylvanica-Chestnut-sided Warbler ....................10-11 days

Dendroica pensylvanica-Chestnut-sided Warbler ........................... days

Dendroica virens-Black-throated Green

Warbler ......................12 days

Black-throated Green Warbler.......12-14 days

Dendroica palmarum hypochrysea-Yellow

Palm Warbler ...................12 days

Dendroica discolor-Prairie Warbler....14? days

Seiurus aurocapillus - Ovenbird........12 days

Seiurus noveboracensis-Water Thrush...14 days

Geothlypis trichas trichas-Maryland

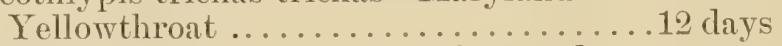

Icteria virens virens-Yellow-breasted

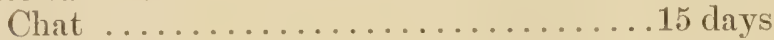

Icteria virens virens-Yellow-breasted

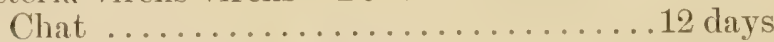

Setophaga ruticilla-Redstart.........12 days

Tanagridae

Scarlet Tanager .................... 13 days

Pyranga rubra-Summer Tanager.......12 days

43

85

3

3

86

183

87

87

3

3

3

1

Ploceidae

Lagonosticta minima-Blood

Finch ................. "about a fortnight"

Lagonosticta minima-Blood Finch......12 days

Hypanti(a sanguinerostris-Blutschnabelweber ............................ days

Poëphila gouldie - Grass Finch.......12-13 days

Icteridae

Dolichonyx oryzivorus-Bobolink........10 days

Molothrus ater-Cowbird... "nearly a fortnight"

Cowbird ...................10-11 days

Molothrus ater ater-Cowbird..........10 days

Argentine Cowbird................111/2 days

Xanthocephalus xanthocephalus-Yellow-

headed Blackbird .................10? days

Yellow-headed Blackbird ...........10? days

3 
Agelaius phoeniceus phoeniceus-Red-winged

Blackbird .................. 10-14 days

Strunella magna magna-Meadowlark. .15-17 days

Strunella neglecta-Western Meadowlark..15 days

Icterus cucullatus nelsoni-Arizona Hooded

Oriole .....................12-14 days

Icterus spurius-Orchard Oriole........12 days

Orchard Oriole .................12-14? days

Icterus galbula-Baltimore Oriole....... 14 days

Icterus galbula-Baltimore Oriole.......14 days

Icterus bullocki-Bullock's Oriole....... 14 days

Euphagus carolinus-Rusty Blackbird....14 days

Euphagus cyanocephalus-Brewer's Black-

bird .........................14 days

Brewer's Blackbird ................12 days

Quiscalus quiscula quiscula-Purple

Grackle ......................14 days

Quiscalus quiscula xneus-Bronzed

Grackle ...................13-16 days

Megaquiscalus major major-Boat-tailed

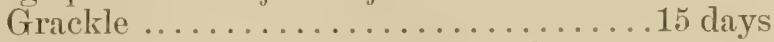

Megaquiscalus major macrourus-Great-

tailed Grackle ......................... days

Fringillidae

Hesperiphona vespertina vespertinaEvening Grosbeak ..............13-14 days

Coccothraustes vespertina-Evening

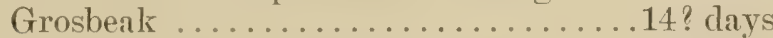

Ligurinus chloris-Greenfinch......... 14 days

Fringilla coelebs-Chaffinch.................. days

Pyrrhula europaea-Bullfinch..........13 days

Erythrospiza githaginea-Trumpeter Bullfinch .............. "within a fortnight" 1

Carpodacus purpureus-Purple Finch....1:) clays 3

Carpodacus mexicanus frontalis-House Finch ..................exactly 14 days

Carpodacus mexicanus frontalis-House Finch ........................... days

Loxia pityopsittacus-Parrot Crossbill . 14-15 days

Loxia curvirostra-Crossbill .......... 14 days

Linota cannabina-Linnet ............14 days

Astragalinus tristis tristis-Goldfinch. . 12-14 days

Carduelis elegans-Goldfinch.........13-14 days

Toeniopygia castanotus-Chestnut-eared Finch ......................14 days

Emblema picta-Painted Finch ................. "took exactly 14 days"

Chrysomitris spinus-Siskin.........13-14 days 
Sycalis flaveola-Saffron Finch..... about 14 days 97

Serinus Canarius-Canary..........13-14 days

Serinus Canarius-Canary ........ exactly 14 days

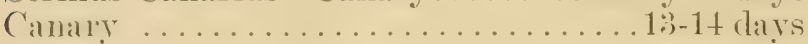

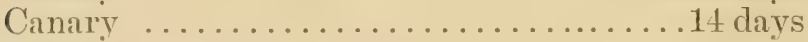

Serinus canarius-Canary............14 days

Serinus hortulanus-Serin.........13 to 14 days

Passer domesticus-House Sparrow.13 and 14 days

Passer domesticus-European House

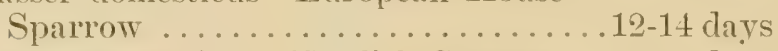

Passer domesticus-English Sparrow... 12-13 days

Passer luteus ................. 13-14 davs

Plectrophenax nivalis nivalis-Snow

Bunting ................21? days

Poaccetes gramineus gramineus-Vesper

Sparrow .................... 11-13 days

Passerculus sandwichensis savanna-

Savannah Sparrow...............12 days

Chondestes grammacus strigatus-IVestern

Lark Sparrow...................12 days

Zonotrichia albicollis-IVhite-throated Sparrow ...................12-14 days

Spizella passerina passerina-Chipping

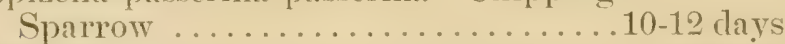

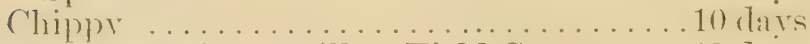

Spizella pusilla pusilla-Field Sparrow . . 13 days

Field Sparrow.............. "12 days or more"

Junco hyemalis-Slate-colored Junco... 11-12 days

Melopsiza melodia melodia-Song

Sparrow ....................10-14 days

Melopsiza georgiana-Swamp Sparrow...13 days

Passerella iliaca schistacea-Slate-colored

Fox Sparrot................12-14 days

Papilo erythrophthalmus erythroph-

thalmis-Towhee .............12-13 days

Cardinalis cardinalis cardinalis-

Cardinal ........................ day's

Cardinalis cardinalis cardinalis-

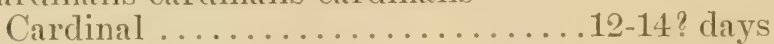

Paroavia cucullata ................14 days

Paroaria larvata ...................... 14 days

Subernatrix cristata.................... days

Volatinia jacarini................. 10? days

Zamelodia ludoviciana-Rose-breasted

Grosbeak ....................... d4ays

Rose-breasted Grosbeak .............. 9? ? days

Coryphospiza cruentus-Purpurkronfink. .11 days

Passerina cyanea-Indigo Bunting.......12 days 
Indigo Bird ................. 10? days 35

Passerina amaena-Lazuli Bunting......12 days 3

Passerina eiris-Nonpareil............14? days 80

Emberiza citrinella-Yellow Hammer.....14 days 1

\section{TABLE NO. 2-BIBLIOGRAPHY}

1. Evans-Ibis, Vol. IIT, p. 52.

2. Evans-Ibis, Vol. IV, p. 55.

3. Burns-IVilson Bull, No. 90, p. 275.

4. Gadow-Encyclop. Brit. Edit. XI, Vol. III, p. 976.

5. A. O. U. Check List. Third Edit. 1910.

6. "Arizona" (Phoenix, Ariz.), Vol. IV, No. 3, p. 5.

7. U. S. Dept. Agric. Yearbook, 1905, p. 400.

8. Am. Poult. Jour. Yearbook, 1914, Breeder's Table.

9. Die Vögel, Reichenow, Band I.

10. Knowlton, Birds of the World, 1909.

11. Cones-Key to North Am. Birds, 1884.

12. Arrigoni-Uंccelli Europei, 1902.

13. Proc. Zool. Soc., London, Apr. 21, 1885, p. 325.

14. Camplell. A. J.- Nests and Egos of Australian Birds.

15. International Encyclop. Vol. XIV, p. 554.

16. Shufeldt-U. S. Nat. Mus. Report, 1892, p. 462.

17. North-Nests and Eggs of Birds of Australia and Tasmania.

18. Youth's Companion, May 28, 1914, p. 287.

19. Bird-Lore, Jan.-Feb. 1915, p. 69.

20. Levic-Antaretic Penguins, 1914.

21. Willet-Auk, Vol. XXXII, p. 297.

22. Dutcher and Bailey-Auk, 1903, p. 431.

23. Roberts-Auk, July, 1900, p. 279.

24. Watson-Auk, Apr. 1909, p. 213.

25. Newton-Dictionary of Birds, 1893.

26. Gross-Auk, Jan. 1912, p. 58.

27. Plath-Bird-Lore, Vol. XV, No. 6, p. 347.

28. Gurney-The Gannet.

29. Birds of New Zealand, Vol. II, p. 181.

30. Barrows-Birds of Michigan, 1912.

31. Harper-Bird-Lore, Sept.-Oct., 1914, p. 341.

32. Strong-Auk, Oct. 1912, p. 482.

33. U. S. Dept. Agric. Farmers Bull. No. 236, p. 8.

34. U. S. Dept. Agric. Farmers Bull. No. 64.

35. Dugmore-Bird Homes.

36. Encyclop. Britt. Edit. XI, Vol. 26, p. 180.

37. Forbush-Game Birds, p. 220.

38. H. Milne-Edwards-Lecon, sur la physiologie et anatomie... animeau.

39. Butch-Bird-Lore, Mch.-Apr., 1915, p. 108. 
40. Chamberlain-B. Rhett-Personal communication.

41. Cameron-Auk, July, 1906, p. 254.

42. Hutton and Drummond-Animals of New Zealand, p. 199.

43. Saunders, A. A.-Personal communication.

44. Bendire-U. S. National Mus. Special Bull. No. 1.

45. Hodge, C. F.-Nature Study Pamphlet, Bobwhite, p. 13 .

46. U. S. Dept. Agricult. Yearbook, 1909, p. 252.

47. Field-Bird-Lore, Vol. XV, No. 6, p. 356.

48. U. S. Dept. Agricult. Bull. No. 24, Biological Survey, p. 24.

49. U. S. Dept. Agricult. Farmers Bull, No. 200, p. 23.

50. Tegetmier-Pheasants, p. 14.

51. U. S. Dept. Agricult. Farmers Bull. No. 234, p. 12.

52. Townsand-Auk, Vol. XXXII, p. 310.

53. Deane-Auk, July, 1896.

5t. Powell, Mrs. Cuthbert-Personal communication.

55. Townsend-Bird-Lore, Vol. XVI, No. 4, p. 279.

56. Sherman-Auk, Vol. XXX, p. 408.

57. U. S. Dept. Agricult. Bull. No. 3.

58. Cameron-Auk, Vol. XXX, p. 170.

59. Cameron-Auk, April, 1914, p. 160.

60. Fisher-U. S. Dept. Agricult. Bull. No. 27, Biological Survey.

61. Cameron-Auk, 1908, p. 253.

62. Cameron-Auk, Vol, XXXI, p. 160.

63. Findley-American Birds, p. 245.

64. Kobbé-Auk, 1900 , p. 15.

65. Chapman-Birds of Eastern North America, 1912, p. 68.

66. Abbott-Home Life of the Osprey.

67. Sherman-Auk, April, 1911, p. 158.

68. Beebe-Bull. N. Y. Zool. Soc.. Tol. XVII, p. 1906.

69. Sherman-Auk, Vol. XXX, p. 412.

70. Sherman-Wilson Bull. No. 72, p. 143.

71. Ridgway-U. S. Nat. Mus. Report, 1890, p. 284.

72. Nichols; .T. T.-Personal communication.

73. Warren-Auk, Jan., 1899, p. 17.

74. Bendire-U. S. Nat, Mus. Report, 1893.

75. Roberts-Auk, 1909, p. 377.

76. Fleming-Auk, April, 1903, p. 214.

77. Bergtold-Auk, Vol. XXX, p. 55.

78. Bergtold-Personal observation.

79. Harvey-Auk, Jan., 1903, p. 56.

80. Weston. F. M.-Personal communication.

81. Jacobs-Story of a Martin Colony.

82. Saunders-Auk, July, 1911, p. 325.

83. Bowdish-Auk, Jan., 1906, p. 16. 
84. Wright-Auk, Oct., 1909, p. 345.

85. Auk. Oct.. 1913, p. 60t (quoting Biggleston, Wilson Bull., Vol. XXV, p. 49).

S6. Stanwood-Auk, Oct., 1910, p. 386.

87. Stanwood-Auk, July, 1910, p. 291.

S8. Bluebird-Vol. VII, No. 4, p. 101.

89. Stanwood-Nature and Culture, May, 1913 (vide Auk, Oct., 1913, p. 613).

90. Judson-Bird-Lore, Vol. XVII. No. 3, p. 213.

91. Tyler-Auk, Vol. XXX, p. 395.

92. Cole and Kirkpatrick-Rhode Island State College, Exp. Station Bull. 162.

93. N. Y. Evening Post, Nov. 6, 1915, "Penguins in Am. Mus. Nat. Hist."

94. Cranclall, Lee S.-Bull. N. Y. Zool. Soc., Vol. XVIII, No. 5, p. 1262.

95. Job-Propagation of Wild Birds, 1915.

96. Boulton-Bird-Lore, March-April, 1916, p. 123.

97. Crandall. Lee S.-Personal communication.

98. Nowotny-Auk, 1898, p. 30.

99. Crandall-Bull. N. Y. Zool. Soc., Oct., 1909, p. 583.

100. Beebe-Bull. X. Y. Zool. Soc., Jan.. 1909. p. 466.

101. Claus, Zoologie, Band ii, p. 34 .

102. Fürbringer-Untersuch. zur Morph....... Vögel.

103. Standard Eneyclop. Vol. IX, p. 395.

104. Woor-Am. Encyclop. Ophthalmology, Vol. IV, p. 2585 .

105. Knight-Birds of Maine (quoted by Burns (3)).

106. Thompson-Bird-Lore, Vol. V, p. 80.

107. Beebe-Zoologica, Vol. I, p. 242.

108. Kendrick, WV. F.-Personal communication.

109. Kendrick, W. F., and Bergtold. W. H.--Personal observation.

110. Ingersoll-Harper's Monthly, Vol. XCVI, p. 40.

111. Rubincam, H. C.-Personal communication.

112. Sutherland-Proc. Zool. Soc., London, 1899, p. 787.

113. Collins, E. TV., and Bergtold, WV. H.--Personal observation.

114. Beebe-Bull. X. Y. Zool. Soc. July, 190t. p. 166.

115. Pycraft-Encyclop. Brit., Edit. XI. Tol. 9, p. 14.

116. Page-Aviaries and Aviary Life.

117. Renshaw-Aviculture Mag., Vol. 7, No. 3, p. 82.

118. Heilmann-Dansk Ornith. Forening. Tidesk.. March, 1915, p. 147.

119. Hornaday-American Natural History.

120. Pycraft-Infancy of Animals.

121. Denby-Nature, Vol. LIX, p. 340.

122. California Alligator Farm, Los Angeles-Personal communication. 
123. Detmers-Reptile Book.

124. Detmers-Zoologica, Vol. I, p. 237.

125. Detmers-Bull. N. Y. Zool. Soc., July, 1904, p. 158.

126. Hawes and Swinnerton-Trans. Zool. Soc., London, Feb., 1901.

127. Jewett-Condor, March, 1916, p. 75.

128. Newberry-Condor, March, 1916, p. 65.

129. Skinner-Condor, March, 1916, p. 64.

130. Whitaker-Ibis, 1899 , p. 502.

131. Le Souëf-Ibis, 1899, p. 9.

132. Gurney-Ibis, 1899, p. 19.

133. Oustalet-La Nature, 1900 , p. 378.

134. Murphy, R. C.-Personal communication.

135. Beebe-Bull. N. Y. Zool. Soc., Jan., 1906, p. 258.

136. La Nature, July 6, 1912.

137. Beetz and Townsand-Auk, July, 1916, p. 287.

138. Pycraft-History of Birds, 1914 .

139. Mills-Animal Physiology, p. 402.

140. Curtis-Maine Agric. Exp. Station, Bull. No. 228, June, 1914.

141. Pickerell, Arizona Ostrich Farm-Personal communication.

142. Bellchambers-So. Australian Ornithologist, April, 1916 (vide Auk, July, 1916).

143. Menegaux-Revue Francais d'Ornith., Oct., 1915 (vide Auk, Jan., 1916).

14t. Internat. Encyclop., Vol. VIII, p. 660.

145. Ridœway-Man. No. Am. Birds, 4th Edition.

146. Macdonald-Auk, Oct., 1916, p. 435.

147. Smith, R. W.-Physiology of Domestic Animals.

148. Howell-Text Book of Physiology, 1915.

149. Bates-TVilson Bull., No. 96, p. 151.

150. Gadow-Bonn's Tier. Reich. Vögel, VI. 4, p. 698.

151. International Encyclop., Vol. I, p. 518.

152. Phillips, Clyde and Bergtold, W. H.-Personal observation.

153. Morgan-So. Australian Ornithologist, July, 1916.

154. Beebe-13ull. N. Y. Zool. Soc., Oct., 1908, p. 459.

155. Encyclop. Britt., Edit. IX, Vol. XX, p. 411.

155. Pombery-Chäfer's Physiology, Vol. I, p. 785.

157. Fuertes, Louis-Personal communication.

158. Mousley-Auk, July, 1916, p. 281.

159. Beebe-Bull. N. Y. Zool. Soc., Jan., 1908, p. 397.

160. Pickerell-U. S. Dept. Igric. Yearbook, 1905, p. 401.

161. Hatch-Birds of Minnesota, p. 73.

162. ITeinroth-Zool. Beobachter, Vol. XLIX, No. 1, p. 14.

163. Blaanw-Aricult. Mag., Vol. VII. No. X, 1916.

16t. Simpson-Trans. Royal Soc. Edinburgh, Vol. XLVII, part 1 , No. 5, p. 607 . 
165. Simpson-1'roc. Royal Soc. Edinburgh, Vol. XXXII, part 1, No. 5, p. 19.

166. Simpson-Proc. Royal Soc. Edinburgh, Vol. XXXII, part 1, No. 11, p. 10.

167. Simpson and Galbraith-Jour. Physiology, Vol. 33, p. 225 .

168. Crisp, E.-Proc. Brit. Soc. Adv. Sci., $186 t$ and 1865, p. 92.

169. Wilbur, A. P., and Watts, E. A.-Personal communication.

170. Post, K. C.-Wilson Bull., Dec., 1916, p. 178.

171. Wetmore, Alex-CI. S. Dept. Agric. Farmers Bull., No. 770 , p. 16.

172. Sherman. A. R.-Wilson Bull., Dec., 1916. p. 196.

173. Spohn and Riddle-Am. Jour. Physiology, Trol. XLI, No. 3, p. 408:

17t. Buchanan-Jour. Physiology (Cambridge), Vol. XXXVIII, 1909, p. 62-66.

175. Colo. Mus. Nat. Hist., F. C. Lincoln--Personal communication.

176. Evans-Birds, 1898.

177. Oberholser-U. S. Nat. Mus. Bull. 86.

178. Meyer-Auk, 1916, p. 82.

179. Hitchcock-Bird-Lore, March-April, 1917, p. 79.

180. Eaton-Birds of New York.

181. Lanning-Wild Life in China, 1911.

182. Colo. Mus. Nat. Hist., R. J. Niedrach-Personal communication.

183. Wilbur-Youth's Companion, Feb. 22, 1917, p. 111.

184. Day-Bird-Lore, June, 1899, p. 78.

18.5. Lucas-Auk, Vol. IV, p. 2.

186. Campbell-Bird-Lore, Jan.-Feb., 1903, p. 5.

187. Seton and Chapman-Bird-Lore, Jan.-Feb., 1904, p. 1.

188. Lemmon-Bird-Lore, May-June, 1901, p. 108.

189. Whitten-Bird-Lore, May-June, 1902, p. 95.

190. Lemmon-Bird-Lore, May-June, 1904, p. 89.

191. Campbell-Bird-Lore, Jan.-Feb., 1903, p. 5.

192. Jackson-Bird-Lore, Nov.-Dec., 1903, p. 184.

193. Moore-Bird-Lore, Sept.-Oct., 1902, p. 162.

194. Hegner-Bird-Lore, Sept.-Oct., 1906, p. 154.

195. Shufeldt-Auk, July, 1893, p. 304.

196. Heil-Bird-Lore, May-June, 1908, p. 101.

197. Heil-Bird-Lore, July-Aug., 1909, p. 158. 






SMITHSONIAN INSTITUTION LIBRARIES

|||||||||||||||||||||||||||||||||||||||||||||||||||||||||||||||||

nhbird OL698.B49

A study of the incubation periods of bir 